\title{
Freedom road: Black refugee settlements in northwestern Pennsylvania, 1820-1870
}

Timothy P. Konhaus

West Virginia University

Follow this and additional works at: https://researchrepository.wvu.edu/etd

\section{Recommended Citation}

Konhaus, Timothy P., "Freedom road: Black refugee settlements in northwestern Pennsylvania, 1820-1870" (2010). Graduate Theses, Dissertations, and Problem Reports. 3234.

https://researchrepository.wvu.edu/etd/3234

This Dissertation is protected by copyright and/or related rights. It has been brought to you by the The Research Repository @ WVU with permission from the rights-holder(s). You are free to use this Dissertation in any way that is permitted by the copyright and related rights legislation that applies to your use. For other uses you must obtain permission from the rights-holder(s) directly, unless additional rights are indicated by a Creative Commons license in the record and/ or on the work itself. This Dissertation has been accepted for inclusion in WVU Graduate Theses, Dissertations, and Problem Reports collection by an authorized administrator of The Research Repository @ WVU.

For more information, please contact researchrepository@mail.wvu.edu. 


\title{
Freedom Road: Black Refugee Settlements in Northwestern Pennsylvania, 1820 - 1870
}

\author{
Timothy P. Konhaus
}

Dissertation submitted to the College of Arts and Sciences at West Virginia University in partial fulfillment of the requirements for the degree of

Doctor of Philosophy

in

History

\author{
Kenneth Fones-Wolf, Ph.D., Committee Chair \\ Elizabeth Fones-Wolf, Ph.D. \\ Michal McMahon, Ph.D. \\ Tyler Boulware, Ph.D. \\ Diane Barnes, Ph.D.
}

Department of History

Morgantown, West Virginia

2010 


\section{ABSTRACT \\ Freedom Road: Black Refugee Settlements in Northwestern Pennsylvania, 1820 - 1870}

\section{Timothy P. Konhaus}

In the first half of the nineteenth century many blacks fled from slave states looking to escape the oppression of bondage. These people largely fell into two categories; the first group fled the oppression of bondage, and readily sought freedom by taking flight, while the latter group already free, sought to avoid the possibility of legal codes forcing them back into bondage. Between 1820 and 1870, two groups of black settlers arrived in Mercer County, Pennsylvania looking for a refuge from chattel slavery. Although each group arrived under different circumstances, they shared a common refugee experience. The historiography of black resettlement efforts in the North has focused on qualifying these efforts as either successes or failures. In doing so the studies of black resettlements usually views the settlements over a relatively brief period, depending upon the measure of success they met with. At the same time, the historiography has attempted to affix credit or blame for the relative successes and/or failures of the resettlement efforts. Furthermore, this approach at least portrays black refugees and their communities as passive victims and at most inept and unqualified to establish themselves socially and economically within the broader American community.

The duration of the physical settlements is less indicative of success or failure but rather the degree of usefulness and their ability to continue providing a refuge from slavery and self-determination. This work suggests that, not only is a more prolonged study needed, it is a necessity to better understand the black refugee experience. Only in studying these communities as a series of processes or steps in the refugee experience can historians better understand the black resettlement efforts of the early and mid 19th century. Although many blacks sought refuge in northern states like Pennsylvania, and frequently within white antislavery communities, they found themselves not always welcomed and sometimes struggled to adapt within the host communities. This dissertation then, explores the ebb and flow of optimism and disillusionment. It is also about the story of the formation, dissolution, and re-formation of rural black communities and the black refugee experience in the North. 


\section{TABLE OF CONTENTS}

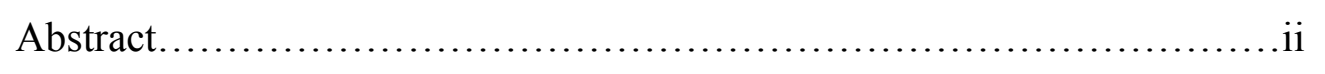

Table of Contents................................................

Refugees in Search of Freedom.....................................

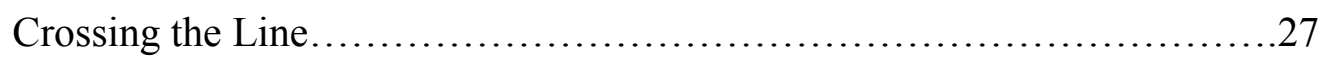

Uncovered Partridges...........................................56

Peculiar Conflicts................................................ 92

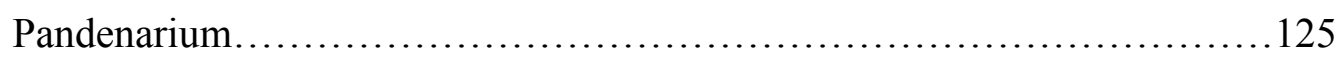

The Long and Winding Road to Freedom............................ 173

Selected Bibliography ............................................ 198 


\section{CHAPTER 1}

\section{REFUGEES IN SEARCH OF FREEDOM}

When in any State, the oppression of the laboring portion of the community amounts to an entire deprivation of their civil and personal rights; when it assumes to control their wills, to assign tasks, to reap the rewards of their labor, and to punish with bodily tortures the least infraction of its mandates, it is obvious that the class so overwhelmed with injustice, are necessarily, unless prevented by ignorance from knowing their rights and their wrong, the enemies of the government. ${ }^{1}$

- Benjamin Drew

In the second half of the twentieth century, scholars began studying refugees and the circumstances surrounding their plight in earnest. The aftermath of World War II, in no small part, prompted this development of refugee studies as politicians and aid agencies struggled to assist thousands of Europeans displaced by the war. To better organize and assist the affected persons, leaders recognized a need to gauge the specific needs of refugees. Those same leaders also recognized the inherent limitations in financing relief services; providing refuge frequently meant large-scale capital investment and continuous investments of the like quickly taxed those offering aid. In response to these limitations world leaders more narrowly defined who and what a refugee is. Defining refugee with the narrowest of definitions reduced the number of persons requiring refuge and assistance, and thereby reduced the financial strain upon aid givers. Their efforts culminated in the United Nations Refugee Convention of 1951, which held that a refugee is:

\footnotetext{
${ }^{1}$ Benjamin Drew, A North-Side View of Slavery. The Refugee: or the Narratives of Fugitive Slaves in Canada, (Boston: John P. Jewett and Company, 1856), pp. 1.
} 
[someone who] owing to a well-founded fear of being persecuted for reasons of race, religion, nationality, membership of a particular social group or political opinion, is outside the country of his nationality and is unable or, owing to such fear, is unwilling to avail himself of the protection of that country, or who not having a nationality and being outside the country of his former residence, is unable or, owing to such fear is unwilling to return to it. ${ }^{2}$

This legal definition is far narrower in scope than the popular assumption that a refugee is simply anyone forced to leave his or her home in search of safety. World leaders paid careful attention to the factors prompting refugees to take flight. According to the UN, crossing an international border predicates refugee status, failure to do so leaves people in an ambiguous internally displaced state. This well crafted legal definition is forward looking in its approach in that it anticipates refugee crises to better provide a "professional refugee assistance program."3

The efforts of world leaders and social scientists to understand and assist in relief efforts focus almost exclusively upon the modern era, but refugee crises were not exclusive to the twentieth century. Sociologist Barry Stein has noted that, "refugee problems are [often] viewed as temporary and unique events," and that "this inaccurate perspective is ... most corrosive and damaging." ${ }^{4}$ The financial limitations, which restrict efforts of world leaders and social scientists, do not bind historians. The historian need not worry about the dilemma of funding a current refugee crisis or even future crises. This does not mean that historians should discount the efforts of modern refugee studies: to the contrary the information and insight those studies offer is often applicable

\footnotetext{
${ }^{2}$ United Nations Refugee Convention, Article 1A.

${ }^{3}$ Barry Stein, "The Refugee Experience: Defining the Parameters of a Field Study" International Migration Review, Vol. 15, No. 1/2, Refugees Today. (Spring-Summer, 1981), p. 320.

${ }^{4}$ Stein, p. 320.
} 
to past refugee crises. Accordingly this data can be used to better interpret the historical record of refugee crises from centuries long past. However, such accounts require defining refugee; primarily the definition must be broader and more geographically inclusive.

The aptly titled, "peculiar institution" of chattel slavery in the United States is illustrative of the problems of geography. When white southerners began using this euphemism to talk about slavery they did so in rather loaded terms. They did not intend to describe slavery as queer and inhumane practice; instead, their goal was to illustrate the system's spatial orientation. Chattel slavery, as they saw it, had become an institution unique, or peculiar, to the southern portion of the United States. But also implicit in the euphemism was a sense of nationalism or national identity. Herein lies the problem with the U.N. definition of refugee status: if an enslaved black fled from the South into the North they did not cross any formal international boundary. Yet these blacks who took flight to escape slavery were in search of not only freedom but also safety. By the mid nineteenth century, many white Americans both North and South believed there were concrete differences politically, economically, and socially between the two sections. Even without these perceived differences, the peculiar institution was regulated less on a federal level and more so on a state-to-state basis. The Constitution provided no legal basis for slavery, and the absence of even the words slave or slavery clearly indicates the decision to regulate the system on a state level. For those fleeing the persecutions associated with chattel slavery, state borders were as important to defining refugee status as international borders. Although international borders existed to the north and west of the United States, black refugees did not necessarily seek refuge in large numbers in 
either direction until after 1850. Instead, enslaved blacks sought out areas of refuge more readily accessible. Crossing the informal boundary between North and South offered more immediate emancipation, physically though not necessarily legally, for enslaved blacks.

Although these crossings did not constitute an international flight, the development of sectionalism in the first half of the nineteenth century gave the illusion of two distinct nations. The socio-economic development of the two sections differed markedly. If the development of sectionalism provided a ray of hope for enslaved blacks, it frustrated southern slaveholders. The amount of capital invested in slave labor meant slaveholders had a stake in preventing escape. In a petition to Congress, several Maryland slaveholders complained that they were "greatly aggrieved at the difficulties of Obtaining [their] Runaway slaves, in many of the Non Slave States, and very frequently suffer the entire loss of them." This financial inducement added to the peculiarity of the refugee crisis in the United States. Unlike most refugee patterns, black refugees in America faced the threat of recapture and the return to bondage. Slaveholders lobbied long and hard for assistance in preventing escape and, in the event escape was unavoidable, they sought assistance in reclaiming their chattel. States along the border between North and South became the battleground for property rights versus personal liberty, and the ground over which black refugees traversed to gain freedom.

Chattel slavery prompted thousands of Africans and Africans-Americans to take flight for more than two centuries in North America. Despite arguments that some Africans actually arrived in the Americas of their own accord prior to European

${ }^{5}$ Memorial to the Senate and House of Representatives of the United States, 1838 (Slavery - Runaway Papers, Harford County Historical Society; Bel Air, Maryland). 
exploration, the vast majority of African people reaching the New World between the $17^{\text {th }}$ and $19^{\text {th }}$ centuries came via the trans-Atlantic slave trade. ${ }^{6}$ The first Africans to venture into North America aboard European ships arrived in Jamestown aboard a Dutch trading vessel in 1619. Although historians debate whether these early African arrivals were enslaved or indentured servants, not long after their arrival the trans-Atlantic slave trade between Africa and European colonies in North America began in earnest.

Even the trafficking of human beings across the Atlantic Ocean fails to meet the modern guidelines for refugee status. The trans-Atlantic trade displaced millions of Africans from their homes and families and forcefully relocated them in the Americas. For many enslaved Africans confusion and fear reigned as they struggled to understand the European concept of slavery. Olaudah Equiano articulated the fears that many suffered when he talked about being loaded onto a slave ship:

When I was carried on board I was immediately handled, and tossed up, to see if I were sound, by some of the crew; and I was now persuaded that I was got into a world of bad spirits, and they were going to kill me. Their complexions too differing so much from ours, their long hair, and the language they spoke, which was very different from any I had ever heard, united to confirm me in this belief. ${ }^{7}$

These experiences so afflicted some Africans that rather than face an uncertain fate they chose to take flight. However, the flight route that many took early in the transAtlantic slave trade seems rather macabre; they chose suicide. More than a few Africans jumped from the slave ships into the ocean, so that even in a spiritual sense they were perhaps seeking refuge from bondage. Equiano himself pondered the possibility and

\footnotetext{
${ }^{6}$ Ivan Van Sertima, argued in 1976 that Africans reached the shores of the Americas centuries before Europeans. Ivan Van Sertima, They Came Before Columbus: The African Presence in Ancient America (New York: Random House, Inc., reprint edition 2003).

${ }^{7}$ Paul Edwards, ed., Equiano's Travels (New York: Praeger, 1967) p. 25
} 
"would have jumped over the side, but ... could not ... [because] the crew used to watch [them] very closely."8 Slavery displaced millions of native-born Africans, and if given the opportunity many would undoubtedly have chosen to return to their respective nations. However, their forced relocation also forced new national identities upon them. Whether or not they chose to accept those identities, the reality of the situation was that those who had enslaved them determined their fates. It was from these conditions that enslaved blacks sought to escape.

Telling in Olaudah Equiano's observations about the crew aboard slave ships is the fact that the crew kept close watch over their cargo. Certainly, some of this attentiveness intended to prevent revolts like the one that occurred on the Amistad, but crews also paid attention to prevent attempts at suicide. The financial investment tied up in slaves ensured that all those profiting from the trade keep slaves from escaping. Ship captains and slaveholders alike sought to keep Africans enslaved not drive them away or drive them to suicide. So while ship captains guarded against Africans jumping overboard, slaveholders guarded against escape. Slaveholders were not excited about the financial loss incurred when blacks fled in search of freedom; their concern for finances ultimately led to legislation making flight illegal. In a strictly legal sense, then, blacks who fled from bondage were not refugees but fugitives, as defined by the laws of the slaveholders. Therein lies the crux of the matter: only in the eyes of the slaveholders and the laws they enacted to protect their property were blacks fugitives. This does not pretend to suggest that blacks who took flight did not think their actions were inoffensive to whites; they certainly understood the implications of their actions hence the need for

\footnotetext{
${ }^{8}$ Ibid.
} 
speed and secrecy in their escape. However, those who took flight also understood that chattel slavery oppressed them and that the oppression was unjust and undeserved. Unfortunately, for those poor souls oppressed by slavery, they did not make the laws nor did they have any say in preventing the laws, which reduced them to bondage.

The uncertainty that Equiano spoke of no doubt plagued many enslaved Africans. Held in bondage against their wills by armed captors, few options existed for the enslaved. With rare exceptions like the Amistad Revolt, physical force to regain freedom was futile as slave traders held the upper hand. ${ }^{9}$ Flight, even if that meant taking their own lives, was the most viable option for the bonds-people. Arrival in the Americas only magnified the challenges to gaining freedom. Flight in the new land proved difficult to Africans who had no idea where they were or where they could find refuge and safety. Even Africans who lived in the Americas long enough to gain an understanding of the colonial boundaries faced obstacles to their flight. Because all of the European colonizers practiced chattel slavery to one degree or another flight from one colony to the next brought no assurance of freedom. Enslaved Africans were simply more likely to find themselves enslaved by another master. Rather than fleeing to another colony Africans set their sights on the wilderness of North America. To be sure, they probably had little sense of where they were headed other than away from their European captors. For Europeans these fugitives did not cross any appreciable international boundary, they simply escaped beyond the reach of European control.

\footnotetext{
${ }^{9}$ In the Amistad Revolt, Africans held in bondage aboard a slave ship [the Amistad] successfully ovethrew the white crew and took control of the ship. The success of this revolt owed much to the fact that the Amistad was on open water when the slaves staged their violent revolt. Once on open water the white crew was not readily able to call upon other whites for assistance in suppressing the revolt.
} 
African people did not suffer the oppression of slavery alone in the European colonies; the colonizers enslaved Native Americans as well. In fact, the initial forays into slavery in the new world depended not on Africans but rather the indigenous peoples. The shared experience of enslavement helped establish a bond between Africans and Native Americans. For Africans, the earliest escapes were no doubt frightful experiences. Enslaved blacks freshly arrived from the African continent found themselves removed from familiar surroundings and frequently among persons who did not share the same language. In the wilderness, any international boundary they crossed belonged not to the European colonizers, but to the Native American peoples. In more than a few instances, these early black refugees found assistance in nearby Native American communities. Native Americans frequently frustrated Europeans by welcoming black refugees into their communities. Of the Five Civilized Nations of the southeastern United States, the Seminoles welcomed enslaved blacks in such numbers as to create a new ethnic group, the Black Seminoles. ${ }^{10}$

As the European colonizers jockeyed for control of North America, their colonies expanded, as did their system of chattel slavery; between 1619 and 1776 slavery spread to all the English colonies in North America. Gradually Great Britain succeeded in gaining control of eastern North America, and as the British increased their landholdings, they forced Native Americans westward. The expansion of the English colonies coincided with the expansion of slavery within its territories. "[Slavery] grew like a cancer, at first slowly, almost imperceptibly, then inexorably, as colonists eager for

\footnotetext{
${ }^{10}$ Kenneth W. Porter, The Black Seminoles, (Gainesville: The University of Florida Press, 1996).
} 
material gain imported hundreds of thousands of Africans to toil in their fields." ${ }^{11}$ The exponential growth of chattel slavery in the American colonies dictated a natural increase in the level of resistance from those enslaved. The numerous modes of resistance required an equally complex system of securing slavery. The security of the slave system depended upon three groups: the slaveholders, military/paramilitary bodies, and the courts. To secure the system of slavery these groups worked in close cooperation with one another, if not in unison. Resistance, expansion, and security shared a symbiotic relationship so that when one entity grew so did the others.

Slaveholders stood on the front line between the system of slavery and resistance. Their direct and immediate contact with the slaves made them the first line of defense in the preservation of chattel slavery in America. Slaveholders were not ill equipped to deal with resistance. In fact, they were the one group that could best head of resistance before it even got started. The system of chattel slavery depended upon the total subordination of the slaves themselves; to that end, slaveholders had a wealth of tools at their disposal to secure subordination. With a combination of paternalism, fear, religious indoctrination, and faux intellectualism they sought to create a sense of dependency within their slaves. Their hope was to convince the slave populations that without slavery they would be hopelessly lost and miserable. The foundation for slavery depended upon controlling and securing a psychological acquiescence from Africans and African-Americans. Without this acquiescence, there was really no hope in sustaining chattel slavery for any length of time.

\footnotetext{
${ }^{11}$ Peter Kolchin, American Slavery, 1619 - 1877, (New York: Hill and Wang, 2003), pp.
} 4. 
Blacks were not naïve as to how slavery attempted to secure their passive acquiescence; consequently, slaveholders sometimes needed assistance in securing the subordination of their slaves. In the event that a slave or group of slaves defied the psychological imperialism of the slavery, which was not uncommon, slaveholders turned to physical force to secure subordination. The system of slavery in the U.S. gave slaveholders wide latitude in meting out punishments to secure subordination. Sometimes the level of brutality involved knew no boundaries as evidenced by an 1851 Virginia case wherein an insubordinate slave was whipped until the slaveholder was exhausted, who then ordered another slave to apply fire "to the body of the slave; about his back, belly and private parts." Apparently convinced such tortures were insufficient in securing obedience, the slaveholder then had the poor victim washed with hot water in which he [the slaveholder] had steeped red pepper pods, and finally choked the bondsman with a rope until dead. Now, death by no means secured the obedience of the tortured soul, but any other witnessing the process understood the message sent by the savagery. They knew that a similar fate awaited them if they failed to subordinate their persons entirely to the slaveholder. However, of note in this case, the slaveholder testified in court that he did not intend to kill the slave; he firmly believed that the slave in question continued his defiance until the end by feigning his suffering. ${ }^{12}$ Although it is doubtful in this case that the tortured man was feigning his suffering, the slaveholder's assertion does

\footnotetext{
${ }^{12}$ Helen C. Catterall, Judicial Cases Concerning American Slavery and the Negro, Vol. 1 (Washington, D.C.: Carnegie Institute of Washington, D.C., 1926), p. 150, and 223 234 and Herbert Aptheker, American Negro Slave Revolts (New York: Columbia University Press, 1943), p. 66.
} 
point to a means of resistance by the enslaved. It was not unheard of for slaves to feign or exaggerate their level of suffering to alleviate further punishment. ${ }^{13}$

If the slaveholder's use of physical force proved insufficient, they could rely on aid from military and paramilitary groups to suppress resistance. On a local level, armed slave patrols could and did seek out enslaved blacks who lacked appropriate authorization to travel without supervision, as well as disbanding assemblies of blacks both free and enslaved. Slaveholders regularly called upon these patrols to assist in putting down organized resistance and recapturing wayward slaves. If slaveholders required further assistance, they could turn to colonial militias, and in the extreme - government troops. The organization and numerical superiority of these paramilitary bodies served as a deterrent to wholesale insurrection. The level of military preparedness in the fledgling United States so struck Englishman Francis Baily, that he commented of the white community in 1796, "The fact is, they are all soldiers." 14

The efforts of slaveholders would have been futile were it not for the legal sanctioning of slavery. The codification of slavery provided slaveholders with the legal right to claim blacks as chattel, but also provided the means to sustain and expand slavery. The courts defined slavery in America, and set perimeters for suppressing resistance. Judge Thomas Ruffin explained the relationship between the slaveholder and the courts when he stated that, "The power of the master must be absolute, to render the

${ }^{13}$ Eugene D. Genovese, Roll, Jordan, Roll: The World the Slaves Made, (New York: Vintage Books, 1976), p. 620; Bauer and Bauer, "Day to Day Resistance to Slavery," Journal of Negro History, XXVII (October, 1942), pp. 406 - 412; and George Skipwith to John H. Cocke, 8 July 1847, in Slave Testimony: Two Centuries of Letters, Speeches, Interviews and Autobiographies, (Lousiana State University Press: Baton Rouge, 1977), pp. $66-68$, John W. Blassingame, ed.

${ }^{14}$ Francis Baily, Journal of a Tour in Unsettled Parts of North America in 1796 and 1797 (London, 1856), p. 99. 
submission of the slave perfect." ${ }^{15}$ It was the courts that supported a slaveholder's unbridled right to property and the right to suppress resistance through brutal means if necessary. Upon this legal foundation slaveholders set about pacifying their chattel and repressing any notion of a life outside of slavery.

The eighteenth century, ushered in dramatic changes for the English colonies, which held long-term consequences for slavery and those enslaved. A new sense of intellectualism swept over Europe and the colonies alike. The new age of Enlightenment prompted colonists to speak of natural rights, equality, and political and religious freedom. Those same ideals became the foundation for Revolutionary rhetoric just a few decades later. By the last quarter of the century, many colonists compared their position relative to Great Britain to that of slaves and their masters. The significance of such analogies was not lost on enslaved blacks in the colonies. In 1773, enslaved blacks in Massachusetts applauded the legislative efforts of the High Court, "to free themselves from slavery," but pleaded with the soon-to-be patriots not to forget enslaved blacks: "take our deplorable case into serious consideration, and give us that ample relief from, as men, we have a natural right to." ${ }^{16}$ Many both black and white, recognized the inherent hypocrisies of the Revolutionary calls for freedom, natural rights, and equality. Little more than half a century later, Martin Delany observed that,

The United States, untrue to her trust and unfaithful to her professed principles of republican equality, has also pursued a policy of political degradation to a large portion of her native born countrymen, and that class is the Colored People. Denied an

\footnotetext{
${ }^{15}$ Catterall, Vol. 2, p. 57.

16 "Slaves Petition for Freedom During the Revolutionary War," found in Herbert Aptheker, ed. A Documentary History of the Negro People in the United States (New York: The Citadel Press, 1951), pp. 6 - 9 and Joanne Grant, ed. Black Protest: 350 Years of History, Documents, and Analyses, (New York: Ballatine Books, 1968), pp. 22 - 24.
} 
equality not only of political, but of natural rights, in common with the rest of our fellow citizens, there is no species of degradation to which we are not subject. ${ }^{17}$

New state constitutions attempted to navigate the pitfalls of slavery and emancipation. Even before the war ended, many northern states began abolishing slavery within their borders. Abolishing slavery within northern states had less of an economic impact than doing the same in the South. In describing slavery in the South, John Cairnes explained in 1863 that,

The political tendencies of the Slave Power ... are determined in principal degree by the economic necessities under which it is placed by its fundamental institution; and in order, therefore, to appreciate the nature of those tendencies, a determination of the conditions requisite for the success of slavery, as an industrial system, becomes indispensable. ${ }^{18}$

In northern colonies, slavery existed as a luxury reserved for those who could afford the expense, but in the southern colonies where enslaved blacks satisfied the demand for labor, the institution was more firmly entrenched. Any attempt to abolish slavery in southern states rested upon the ability to recover the capital invested in slave labor. The first state to abolish slavery legislatively was Pennsylvania in 1780; that year, the state passed An Act for the Gradual Abolition of Slavery. ${ }^{19}$

Other northern states soon followed Pennsylvania's example; Connecticut and Rhode Island followed suit in 1784, and New York and New Jersey, under more

${ }^{17}$ Martin Robison Delany, The Condition, Elevation, Emigration and Destiny of the Colored People of the United States (Reprint Edition; Salem, New Hampshire: Ayer Company Publishers, 1988), pp. 14.

18 John E. Cairnes, The Slave Power, Its Character, Career, and Probable Designs (Reprint edition; New York: Augustus M. Kelley Publishers, 1968), pp. 32.

${ }^{19}$ An Act for the Gradual Abolition of Slavery. Pennsylvania Statutes at Large 10, 67 (1780) and An Act to Explain and Amend "An Act for the Gradual Abolition of Slavery." Pennsylvania Statutes at Large 13, 52 (1788). 
contentious circumstances both allowed for gradual emancipation by 1804 . In Massachusetts and New Hampshire, the judicial process abolished slavery and not legislative methods. In the case of Commonwealth v. Jennison, Massachusetts Supreme Court Justice William Cushing explained the sentiment of the two states when he declared that:

the idea of slavery is inconsistent with our own conduct and Constitution; and there can be no such thing as perpetual servitude of a rational creature, unless his liberty is forfeited by some criminal conduct or given up by personal consent or contract. ${ }^{20}$

The decision of the Massachusetts High Court provided enslaved blacks with a measure of hope that another channel may exist to gain freedom from bondage. Pointing to the ideological origins of the American Revolution enslaved blacks increasingly sought release from bondage in the same courts that upheld a slaveholder's right to property. It was in these courts that enslaved blacks found a tool of resistance; they could sue for their freedom. As a nation of laws, enslaved blacks reasoned that the courts could provide the redress of their condition.

When we think of successful or even popular forms of resistance to oppression, we tend to think of confrontation and violence. However, successful resistance strategies need not confront the object or person of oppression to be successful, they can be just as effective, if not more so, in non-confrontational forms. In the case of slavery, evidence indicates that confrontational and violent forms or resistance were not only rarer, but also less likely to succeed than non-confrontational forms. Of 1,294 slave cases heard in the high courts of the United States between 1790 and 1870, only 284 of those cases involved

\footnotetext{
20 "Minutes from the case of Commonwealth v. Nathanial Jennison," Proceedings of the Massachusetts Historical Society, Vol. 1873 - 1875, pp. 294.
} 
violence. Conversely, cases, which involved suing for freedom or flight, totaled 1,176. That means that roughly $91 \%$ of all slave cases, which came before the high courts over this eighty-year period were nonviolent and subsequently non-confrontational. ${ }^{21}$ As James Scott argues in his work, Weapons of the Weak: "Not only are the circumstances that favor large-scale ... uprisings comparatively rare, but when they do appear the revolts that develop are nearly always crushed unceremoniously.",22

In the wake of failure, slaveholders tightened their grip on the chains of bondage and increased both the codification of slavery and the military support of the same, so much so in fact, that even free persons of color felt the effects of failed insurrection. Following insurrections states enacted more stringent slave codes, which restricted the movement of enslaved blacks, inhibited meetings of groups of blacks, and attempted to suppress any notions of liberty imparted to enslaved blacks by the presence of free persons of color. States in which violent insurrections occurred quickly clamped down on the limited freedoms of their free black populace, often expelling free blacks from their borders. Not unlike its neighbors further south, Virginia enacted legislation in 1806, which gave free blacks twelve months to leave the state or face enslavement. Not coincidentally, in the seven years prior to the legislation's passage, slave revolts took place in Henrico, Southampton, and Nottoway Counties as well the city of Petersburg. Perhaps most frightening to whites was Gabriel's Revolt in 1800; enslaved blacks planned to attack Richmond, kill all the white slaveholders, kidnap Governor James Monroe and raze the city. Governor Monroe articulated what many felt about the rise in

\footnotetext{
${ }^{21}$ Catterall, Vol. 1 - 5 and Marion J. Russell, "American Slave Discontent in Records of the High Courts," The Journal of Negro History, Vol. 31, No. 4 (October, 1946), pp. 414 $-417$.

${ }^{22}$ James Scott, Weapons of the Weak (New Haven: Yale University Press, 1985), p. 29.
} 
slave revolts and the free black population when he addressed the Speakers of the

General Assembly in 1802:

A variety of causes contribute to produce this effect, among which may be enumerated the contrast in the condition of the free Negroes and slaves, the growing sentiment of liberty existing in the minds of the latter, and the inadequacy of the existing patrol laws. ${ }^{23}$

The larger the number of blacks the higher the degree of white paranoia, the cumulative effect of insurrection and violent resistance, was to make blacks free and enslaved enemies of the slave state. By 1853, the state legislature of Virginia contemplated expelling all free blacks from the state unconditionally. Commenting on the debate in the legislature, The Richmond Whig cut to the important aspect that blacks "were not voters they had no friends - and were, therefore, fit subjects for the unfeeling and tyrannical experiments of demagogues." 24

Free persons of color frequently found themselves in the same position as those enslaved, and the federal courts not only failed to make any distinction between the two but also in Dred Scott v. Sandford (1857) under Chief Justice Roger Taney bound the fate of the two together. In rendering the decision of the court Taney declared,

The words "people of the United States" and "citizens" are synonymous terms, and mean the same thing. They both describe the political body who ... form the sovereignty, and who hold the power and conduct the Government through their representatives . . . The question before us is, whether the class of persons described in the plea in abatement compose a portion of this people, and are constituent members of this sovereignty? We think they are not, and that they are not included, and were not intended to be included, under the word "citizens" in the Constitution, and can therefore claim none of the rights and privileges which that instrument

${ }^{23}$ James Monroe to the Speakers of the General Assembly, 16 January 1802, Writings of James Monroe, Vol. 3, pp. 328 - 329.

24 "Free Negroes," The Richmond Whig (January 25, 1853) and "Free Negroes," The Richmond Enquirer (February 17, 1854). 
provides for and secures to citizens of the United States. On the contrary, they were at that time considered as a subordinate and inferior class of beings who had been subjugated by the dominant race, and whether emancipated or not, yet remained subject to their authority, and had not rights or privileges but such as those who held the power and the Government might choose to grant them. ${ }^{25}$

Taney's explanation in the Dred Scott decision, cemented that status of free persons of color in the eyes of the federal government. He later expounded on the right of states to confer citizenship as they saw fit, but cautioned that State citizenship did not necessarily confer citizenship into the "Union.,"26 The court's decision in 1857 only compounded the effect of an earlier decision in 1842, Prigg v. Pennsylvania. In Prigg, the court reaffirmed the right of slaveholders to claim their chattel, even if said chattel crossed state borders from slave state to free. Despite the arguments of Thomas Hambly on behalf of Pennsylvania, the courts found that the presumption that all persons of color were slaves was fundamental to a slaveholder's right to property. ${ }^{27}$ Between 1840 and 1860, the Supreme Court affirmed the supposition that all persons of color were enslaved. Neither the court's assumption that all persons of color were slaves first and freemen second, nor Taney's argument that they had no citizenship recognizable in a federal court diminishes their potential status as refugees. If anything, the high court's assertions only strengthened claims, then and now, of the oppressive nature of slavery. This oppression in turn provided the impetus for flight.

\footnotetext{
${ }^{25}$ Roger B. Taney, "Opinion of the Court in Dredd Scott, Plaintiff in Error v. John F. A. Sandford," Scott v. Sandford, 60 US (19 Howard) 393 (1857).

${ }^{26}$ Ibid.

${ }^{27}$ Hambly argued in Prigg v. Pennsylvania, that in states which did not sanction slavery by “prima facie, every man in free." Prigg v. Pennsylvania, US 41 (16 Peters) 575 (1842).
} 
Despite slavery's legal demise in the United States, we still affix the term fugitive to blacks who sought relief from bondage by taking flight. This term fugitive slave is rather problematic for several reasons. Describing these persons in question as fugitives implies a level of criminal activity. For sure, slaveholders believed those who escaped their control and those who assisted them were committing criminal acts. However, Congress recognized the injustice of slavery in the passage of the $13^{\text {th }}$ Amendment, and if it deemed slavery an injustice in 1865 , why do we still give credence to the "peculiar" institution's view of persons of color? Taken literally, the term fugitive does not necessarily confer criminality, but clearly in the case of American slavery, fugitive status was synonymous with criminality. Originally, the Constitution vaguely alluded to escaped bonds-people in the "fugitive-from-labor" clause. This clause attempted to outline a process by which slaveholders could reclaim their less-than-cooperative chattel. However, subsequent legislation in 1793 and 1850 openly discussed fugitive slaves and the process by which slaveholders could reclaim them.

The continued reference to enslaved blacks who challenged slavery by fleeing as fugitives views them only from the vantage point of slavery and slaveholders. Enslaved blacks who fled bondage understood that their actions were not pleasing to slaveholders and undermined the system of slavery but few referred to themselves as criminals. Their actions made them refugees, not fugitives. Defining enslaved blacks as refugees rather than fugitives, lifts the stigma of criminality and sheds new light into the courageous efforts of enslaved blacks to resist slavery. The term "fugitive slave" also places the efforts of free blacks who sought reprieve from slavery in an ambiguous state. The consistent efforts of states like Virginia to abolish free black populations within their 
borders pushed many blacks out of their homes and into the plight of a refugee. Make no mistake, although slavery was not friendly towards blacks many still viewed their respective states as home and reflected fondly upon them. William Green's sentiments no doubt reflected the thoughts of others when he declared that, "The land of our birth and of our fathers, we cannot repose under the spreading wings of the eagle." ${ }^{28}$ The legal system of the United States placed free and enslaved blacks in the same position relative to federal law, neither had any rights, which whites were legally bound to respect.

Both free and enslaved blacks suffered at the hands of slavery whether they remained in a slave state or fled to free territories. It was not uncommon for free blacks to consort with and marry enslaved blacks. Families resulting from such relationships faced the threat of separation. Despite having purchased his freedom in 1835, Lunsford Lane struggled to come up with the requisite funding to purchase the freedom of his wife and two children. Within five years, Lane found himself in violation of North Carolina law, which gave him twenty days from legal notification to vacate the state or face the possibility of re-enslavement. The law clearly left Lane without any choice in the matter, and although he attempted to fight his battle in court, he ultimately lost and authorities forced him to leave the state. When he left, he had managed to purchase the freedom of his daughter Laura, but still lacked the funds to secure his remaining family. However, in the process of securing his daughter's freedom, he sold his meager house and other properties; further costs for court fees and an attorney left him penniless. When he left

\footnotetext{
${ }^{28}$ William Green, Narrative Events in the Life of William Green, (Formerly a Slave) Written by Himself (Springfield: L.M. Guernsey, Book, Job, and Card Printer, 1853) reprinted in African American Slave Narratives, Vol. II, Sterling Lecater Bland, Jr., ed. (Westport, Connecticut: Greenwood Press, 2001) pp. 606.
} 
North Carolina, he had nothing but the clothes on his back. ${ }^{29}$ Lane's experiences mirror the experience of many contemporary refugees in that, "A displaced person owns nothing but the spot where he is standing, which is always threatened." 30

As potential enemies of the state, oppression at the hands of slavery literally pushed many blacks out of their native lands and into regions where they could find refuge. It is not coincidence that the movement of blacks across the informal boundary of free and slave territories resembles the patterns of contemporary refugees.

Much of the research resultant from contemporary refugee crises is applicable to black refugees of the early to mid nineteenth century. Sociologist Egon F. Kunz outlined a kinetic model for studying displacement and refugees. His model offers "push-pull" theory; wherein refugees receive a push from their protagonist. The push felt by refugees differs markedly from the experiences of other immigrants who, according to Kunz, feel more of a pull. Unlike other immigrants, a specific destination does not necessarily pull refugees toward it; any destination that removes them from danger is acceptable. ${ }^{31}$ James Pennington, once enslaved in Maryland, reflected upon his decision to flee from bondage and recalled some of the thoughts that perplexed him:

A still more trying question was, how can I expect to succeed, I have no knowledge of distance or direction - I know that

${ }^{29}$ Lunsford Lane, The Narrative of Lunsford Lane, Formerly of Raleigh, N.C.; Embracing an Account of his Early Life, the Redemption by Purchase of Himself and Family From Slavery, and His Banishment from the Place of His Birth for the Crime of Wearing a Colored Skin, Third Edition (Boston: Published by Himself, 1845), reprinted in African American Slave Narratives, Vol. I, Sterling Lecater Bland, Jr., ed. (Westport, Connecticut: Greenwood Press, 2001) pp. 100 - 106.

${ }^{30}$ Mureed Barghouthi, “Songs For a Country No Longer Known” Journal of Palestine Studies, 27/2, 1998.

${ }^{31}$ Egon F. Kunz, "The Refugee in Flight: Kinetic Models and Forms of Displacement," International Migration Review, Vol. 7, No. 2, (Summer, 1973), pp. 125 - 146 and Stein, pp. $321-322$. 
Pennsylvania is a free state, but I know not where its soil begins, or where that of Maryland ends? ${ }^{32}$

Despite any apprehensions, Pennington took his chances seeking refuge outside of his native state of Maryland. In the end, he was not so much concerned with his destination as he was his immediate escape from bondage. For enslaved blacks, warfare and/or a dramatic shift in their socio-political status did not precipitate their flight; bondage was the ever-present push factor prompting their flight. The overriding push from slavery produced an acute refugee movement for enslaved blacks. Many did not necessarily plan in detail or prepare for their journey as Pennington articulated. In fact, once on the move he recalled coming to a crossroads. Not knowing where each road led he quickly concluded not to take the left fork simply because left was to his mind "unlucky.",33

Black refugees like their contemporary descendents found the challenge of securing refuge a frightening ordeal. Arrival in a free state did not always confer refuge and safety; enslaved blacks face the threat of pursuit and capture even within a free state. Blacks seeking to escape bondage or even the threat of bondage, faced many of the same challenges other refugees encounter. Scholars divide the refugee experience into stages, usually beginning with the decision to leave and ending with adjustment and/or

\footnotetext{
${ }^{32}$ James W.C. Pennington, The Fugitive Blacksmith; or Events in the History of James W.C. Pennington, Pastor of a Presbyterian Church, New York, Formerly a Slave in the State of Maryland, United States (Self Published, 1849) reprinted in African American Slave Narratives, Vol. II, Sterling Lecater Bland, Jr., ed. (Westport, Connecticut: Greenwood Press, 2001) pp. 559.

${ }^{33}$ Ibid., 569.
} 
acculturation. Each stage presents its own set of challenges to refugees. ${ }^{34}$ The first phase, deciding to leave, forces potential refugees to consider leaving behind family, friends, loved ones, homes, jobs and any status accrued to that point in their lives. Enslaved blacks were like other refugees in this regard. In fact, for many enslaved blacks the loss of family and friends was an unpleasant reality under slavery. The system of slavery afforded only the slaveholders the ability to decide the fate of their chattel. The decision to leave also forces many refugees to leave behind some measure of status in their homelands. Unlike some refugees, enslaved blacks already existed in a world where few owned more than the spot where they stood. That lack of status was part of the oppression of slavery that blacks sought to escape. Still status was a double-edged sword for black refugees, as slaves there was at least some measure of certainty. Slaveholders provided food and shelter, however meager in some instances, relieving enslaved blacks of the responsibility. Under slavery blacks need not look for work; slaveholders again relieved the burden because they guaranteed work for blacks as bondsmen.

For blacks who made the decision to flee from slavery, a new set of challenges emerged in flight. Homelessness plagued those in flight, and securing the necessities became the primary interest of refugees; food and shelter once taken for granted became an all-consuming labor. Despite the hope and desire for brighter horizons, refugees frequently found their new surroundings unfamiliar and in some instances a bit intimidating. For enslaved blacks leaving bondage, refuge in the free states was not as

\footnotetext{
${ }^{34}$ Barry N. Stein, "The Refugee Experience: Defining the Parameters of a Field of Study" International Migration Review, Vol. 15, No. 1, Refugees Today (Spring - Summer, 1981), pp. 320 - 330. Egon F. Kunz, "Exile and Resettlement: Refugee Theory," International Migration Review Vol. 15, No. 1, Refugees Today (Spring - Summer, 1981), pp. 49.
} 
heavenly as they perhaps originally perceived. As was the case in Pennsylvania, not all of their white neighbors were gracious abolitionists looking to help any way they could, some of the white neighbors willingly turned black refugees over to slave catchers and slaveholders or even attempted to bar their entrance in the first place. Whites from several counties petitioned the state legislature to prohibit blacks from entering the commonwealth. ${ }^{35}$ Frequently refugees find that race inhibits their assimilation into the host community, and in the case of formerly enslaved blacks, their race carried social stigma as well as political ramifications. ${ }^{36}$

If historians can make any distinction between contemporary refugees and black refugees from a century ago, it is that the latter, if enslaved, found themselves hunted upon taking flight. Although an acute sense of urgency existed for some, the dangers of slaveholders discovering a planned escape was reason enough to not make detailed plans. Slave narratives frequently extol the trauma resultant from angry slaveholders who foiled an escape plan. There was little question that a beating was often the reward for escape attempts; the only real was question was the severity of the beating. Enslaved blacks understood all too well the inherent dangers of flight, and their respective decisions to flee bondage rather than stay were not made without due consideration. Flight as much as rebellion or insurrection was an active form of resistance to slavery. In 1856 Benjamin Drew argued that, "insurrection and rebellion are the primary, original duties" in resisting slavery; barring these efforts only "emigration suggests itself as the next

\footnotetext{
${ }^{35}$ Ruth Hodge, ed. African American Resources at the Pennsylvania State Archives (Harrisburg: Pennsylvania Historical and Museum Commission, 2000), pp. 31 - 32. ${ }^{36}$ Kunz, "Exile and Resettlement: Refugee Theory," pp. 49.
} 
means of escaping the evils [of slavery]. ${ }^{, 37}$ With the threat of physical violence hanging over their heads, enslaved blacks did not take the prospect of flight lightly and although some fled for brief periods to exercise a temporary resistance to bondage, the long-term effect was a prolonged crisis.

Sociologist Barry Stein pointed to one of the most glaring misconceptions of the current refugee crises. He argued that, one of the most pervasive obstacles to refugee programs is the perceived temporary nature of the relative crises. ${ }^{38}$ This inability to see the bigger picture is due, according to Stein, to the rapidity of refugee crises; one right after another. Consequently, aid givers and relief workers move from one location to another in short order, dealing with only the most pressing or dire crisis at any particular moment; in doing so the aid givers and relief workers rarely succeed in solving the resultant problems of refugee crises. This is not to suggest that those involved in aid and relief efforts are entirely to blame for the current approach to refugee crises. Much like the medical staff of a hospital emergency room, relief workers confront refugee crises according to severity and need.

Within the historic context of the black refugee experience in the pre-Civil War United States, slavery produced similar misconceptions about slavery and the movement of blacks. William and Jane Pease pointed to some of those misconceptions in Black Utopia: Negro Communal Experiments in America. Not unlike Stein's observations of more recent refugee crises, the Peases' research assumes a measure of uniqueness in black resettlement efforts, either as a communal effort or as efforts consigned to the geography of the United States. The black resettlement efforts taken out of the refugee

\footnotetext{
${ }^{37}$ Drew, pp. 1.

${ }^{38}$ Stein, pp. 320.
} 
context appear as unique efforts confined to the nineteenth century and the institution of slavery. Further, the Peases conclude that black resettlement efforts were fleeting due in no small part to their quick dissipation. Communal efforts continuously struggled and ultimately faded away because they failed to assimilate black refugees into the mainstream of American society; "what was explicitly or implicitly proposed and what was in fact, achieved were far from identical, and the distance between them measures the degree of failure." ${ }^{39}$ Many, but not all, of the resettlement efforts existed for brief durations, a few years at the most. However, do not mistake the brevity in duration for failure. Just as the term fugitive denotes perspective so does the term failure as it pertains to black resettlement efforts. Defining the efforts of black refugees assumes that they shared the same vision and hope of many whites who hosted them or provided refuge. Some of these fleeting communities were nothing more than temporary places of respite; while others transcended spatial orientation and when threatened, members of the community worked in concert to reestablish themselves in another location. Finally, still other communities were less fleeting and survived into the twentieth century.

Two black communities in northwestern Pennsylvania exemplify the varying degrees and duration of respite from the threat of enslavement. The first of these, Liberia, emerged in the 1820 s as a blend of free blacks and formerly enslaved blacks seeking refuge far from the "peculiar institution" of the southern United States. By 1851, this community no longer felt safe in northwestern Pennsylvania because of the passage of the Fugitive Slave Act of 1850. The new legislation prompted these blacks to continue their refugee experience in a newer, safer location. Less than a decade later a second

\footnotetext{
${ }^{39}$ William and Jane Pease, Black Utopia: Negro Communal Experiments in America (Madison, WI: The State Historical Society of Wisconsin, 1963), pp. 160.
} 
group of black refugees settled only a few miles from the first. This second community emerged as a consequence of a deceased slaveholder's desire to emancipate and relocate enslaved blacks formerly under his control. Like their predecessors, these formerly enslaved blacks struggled to make new lives for themselves in a place far from the original homes. By applying a refugee template to these two resettlement efforts historians can better understand the ebb and flow of their black settlers and the community itself. 


\section{CHAPTER 2}

\section{CROSSING THE LINE}

\section{Dear Sir:}

Here is a poor fugitive who needs assistance and direction - Can you lend a helping hand. Through many dangers he has reached this place and I hope he will find friends to assist him and finally reach the desired haven. Can you direct him to someone in Warren who will forward him on towards Canada. ${ }^{1}$

- J.D. Hunt to Erathus Barns

For centuries, the Mason-Dixon Line has been of great social and political importance in American history. During the refugee crisis resulting from slavery, the line took on even greater significance to enslaved blacks. For them the line did more than simply demarcate the political boundary between the lands of the Penn and Calvert families, for seventy years the line represented the difference between slavery and freedom. ${ }^{2}$ By 1820, the year of the Missouri Compromise, the line was a clear source of tension in national politics. In a letter to John Holmes, Thomas Jefferson commented of the mounting tension that, "a geographical line, coinciding with a marked principle, moral and political, once conceived and held up to the angry passions of men, will never be obliterated; and every new irritation will mark it deeper and deeper."3 That the Mason

\footnotetext{
${ }^{1}$ Letter from J.D. Hunt to Erathus Barns, 15 December 1856, Warren County Historical Society, Warren, PA.

${ }^{2}$ In 1780, Pennsylvania passed An Act for the Gradual Abolition of Slavery which abolished slavery within its borders, albeit gradually. Seventy years later the Fugitive Slave Law of 1850 asserted that a bondsperson's escape into a "free" state, such as Pennsylvania, did not necessitate emancipation; to the contrary the Supreme Court ruled in 1854 in Dred Scott v. Sandford that a slaveholder's right to property superseded any rights persons of color may have.

3 Thomas Jefferson to John Holmes, 22 April 1820; The Works of Thomas Jefferson, Vol. 12, Paul Leicester Ford, ed., (New York and London: G.P. Putnam's Sons, 1904 - 05), $158-160$.
} 
and Dixon Line was a source of controversy should come as no surprise; the line was born of controversy. The political boundary between the colonies of Maryland and Pennsylvania had been in dispute since King Charles II granted William Penn and his heirs a charter in 1681 nearly fifty years after Cecilius Calvert received a royal charter from King Charles I for the colony of Maryland. The charters granted Penn and Calvert overlapped and prompted a decades-long dispute over land between the two families. The efforts of English surveyors, Charles Mason and Jeremiah Dixon provided the formal demarcation of the political boundary between Maryland and Pennsylvania in 1768 . However, if observers of the two colonies thought the dispute resolved, twelve years and a revolution later the dispute was born anew in 1780 . The line may have eradicated the property dispute between the Penn and Calvert families, but Pennsylvania's abolition of slavery created another kind of property dispute. Land was still involved to be sure, but the new dispute resulting from Pennsylvania's efforts to abolish slavery revolved around chattel property - the slaves themselves.

The evolution from land dispute to chattel dispute was, as Jefferson observed, "a marked principle, moral and political. ${ }^{44}$ Pennsylvania's original proprietor, William Penn, sought opportunities and perhaps more importantly, places where he could practice his religious faith unhindered. As far as Penn was concerned, a colony across the Atlantic on land he owned privately offered an excellent opportunity. Part and parcel of his religious faith were strong feelings concerning chattel slavery. The Society of Friends to which Penn belonged, took a stand against lifelong bondage before he even set one foot in his new colony declaring that,

\footnotetext{
${ }^{4}$ Jefferson to John Holmes, 22 April 1820.
} 
Whereas there is a common course practiced among Englishmen, to buy negroes to that end that they may have them for service or as slaves forever; for the preventing of such practices among us, let it be ordered that no black mankind or white being shall be forced, by covenant, bond, or otherwise, to serve any man or his assignees longer than ten years...5

This does not suggest that all religiously affiliated Pennsylvanians or even more specifically those affiliated with the Society of Friends, disavowed slavery. Despite early antislavery resolutions, many Quakers not only tacitly approved of slavery, they owned slaves themselves. Mennonites most of German heritage, also settled in the religious tolerant colony of Pennsylvania, and formally articulated their aversions to slavery as well in a resolution directed toward the Quaker leaders of the colony, whom they clearly felt fell short of the mark in opposing chattel slavery. The Mennonite petitioners went so far as to remind their Quaker neighbors of their beloved "golden rule," chiding them for excluding blacks on account of their "descent" and "colour." Although many religious leaders ignored and commonly participated in the system of chattel slavery, religious ideologies nonetheless helped plant the seeds of resistance to slavery. As Pennsylvania developed first as a colony and later as a state, slavery failed in not only a spiritual sense, but the institution also failed to find the economic foothold it found in other colonies and states. Despite brief interruptions, indentured servitude supplied adequate labor for the colony and cereal grains dominated the agricultural enterprises rather than cash crops. The result of the spiritual conflicts over slavery and the lack of an economic foothold

\footnotetext{
5 “Quaker Resolution Against Slavery, 1652," in Black Protest: 350 Years of History, Documents and Analyses, Joanne Grant, ed., (New York: Fawcett Columbine, 1968), 19 -20 .

6 "Resolution of Germantown Mennonites, April 18, 1688," Grant, pp. 20 - 22; and Samuel Pennypacker, "The Settlement of Germantown and the Causes which led to it," The Pennsylvania Magazine of History and Biography, Vol. IV, (1880), 28 - 30.
} 
made slavery a luxury rather than a necessity within Pennsylvania; the same conflicts precipitated changing political principles.

Even as Great Britain and its North American colonies descended into open warfare in the last quarter of the $18^{\text {th }}$ century, slavery remained a point of contention. In a metaphoric sense, the American Revolution provided a dispute over the meaning of slavery and the overlap between slavery in the abstract and slavery in the concrete. For colonists freedom from bondage was political empowerment and the right to property, but for enslaved blacks bondage was less of an abstract concept and more of a concrete reality. Political empowerment while most assuredly welcomed by blacks, was secondary to freedom from bondage. In 1780, still in the midst of the American Revolution, Pennsylvania's legislature passed an Act of Gradual Emancipation. ${ }^{7}$ Other fledgling states also moved to abolish slavery either by legislation or by judicial verdict. However, the states that did so were all located north of the Mason and Dixon Line. In states with a greater economic stake in slavery, a reluctance to abolish the institution coincided. Without exception, the new states south of Pennsylvania preserved chattel slavery out of political and economic necessity. As colonies, two distinct societies developed in British North America, one with slaves and the other dependent upon slaves; as the United States, the two societies became a conflicted nation.

For thousands of blacks held in bondage, the proximity of Pennsylvania's southern border and the ambiguity of the nation's early regulation of chattel slavery created the perception of refuge within the commonwealth's borders. The Articles of

\footnotetext{
${ }^{7}$ An Act for the Gradual Abolition of Slavery (March 1, 1780) and An Act to Explain and Amend "An Act for the Gradual Abolition of Slavery" (March 29, 1788) in "Special Verdict," Prigg v. Commonwealth of Pennsylvania (May 22, 1839); Pennsylvania State Archives, Harrisburg, Pennsylvania.
} 
Confederation deferred to the states any central authority, accordingly the new states regulated slavery on a parochial basis. What might pass as regulation in North Carolina may not pass in Rhode Island; or even more importantly to many blacks, what might pass in Delaware, Maryland, and Virginia did not pass in Pennsylvania. In writing "The Federalist No. 7," Alexander Hamilton pointed to the commercial difficulties under the Articles of Confederation, "Each state, or separate confederacy would pursue a system of commercial polity peculiar to itself," and slavery was as much a commercial enterprise as any other. ${ }^{8}$

Pennsylvania's gradual emancipation act created conflicts with its neighbors almost immediately. If enslaved blacks fled from a state that sanctioned chattel slavery, into Pennsylvania their legal status changed. From the perspective of slaveholder and their respective states, these enslaved blacks became fugitives, but for blacks themselves they were escaping bondage and oppression. No longer held in bondage, these black refugees could potentially claim freedom under Pennsylvania's gradual emancipation statutes. Fearing financial losses, slaveholders living near Pennsylvania's borders felt threatened by the possibility their chattel property might flee. Though crossing the line signified passing from one state, which sanctioned slavery, into one that did not, scorned slaveholders dictated that black refugees maintain a measure of discretion in their presumed refuge. At least until 1842, the laws of Pennsylvania did not assume blacks to be chattel primarily, but slaveholders did not concede the same. ${ }^{9}$ This meant that the

\footnotetext{
8 "The Federalist No. 7," 17 November 1787 in The Federalist Papers (Cutchogue, NY: Buccaneer Books, Inc., 1992), 29.

${ }^{9}$ Although the Fugitive Slave Act of 1793 specifically acknowledged an enslaved black's perpetual servitude regardless of geography, the law was not tested until Prigg vs.
} 
black refugees who came to Pennsylvania in the first half of the $19^{\text {th }}$ century had to be weary and vigilant at all times of their surroundings and the persons they encountered. With care and time, many black refugees thwarted the efforts of their former oppressors with aid from the commonwealth's legislative codes.

Without a more centralized authority, slaveholders seeking to recapture lost chattel property found themselves at the mercy of the courts in Pennsylvania. Although the ratification of the federal Constitution in 1788 provided a vehicle for stronger centralized authority, the Constitution did very little to change the status quo in regards to slavery in the United States. Black refugees fell under the "fugitive-from-labor" clause of the Constitution, which declared that

No person held to Service or Labour in one State under the laws thereof, escaping into another, shall in Consequence of any Law or Regulation therein, be discharged from Service or Labour, but shall be delivered up on Claim of the Party to whom such Service or Labour may be due. ${ }^{10}$

This very simple clause failed to address some very important considerations in recapturing lost chattel. First, to whom were claims of ownership made? Secondly, how was ownership verified? Lastly, assuming human chattel had crossed state lines, what was the process for returning them to the state in which they are "held to Service or Labour?" On paper at least, enslaved blacks could not use political geography to affect their status as chattel, in other words simply crossing into a free state did not legally release them from their "service of labor." However, all of the aforementioned questions created ambiguity and opened the door to conflicting legal interpretations. Since the

Pennsylvania (1842) which upheld the nationalization of slavery, and a slaveholder's right to property, Prigg v. Pennsylvania, 41 US (16 Peters) 539 (1842).

${ }^{10}$ US Constitution, art. IV, sec. 2. 
clause failed to outline a specific process by which slaveholders could reclaim their lost chattel, states regulated the process, and not always in harmony with one another.

The ambiguity of the clause was such that within five years a dispute between Virginia and Pennsylvania compelled the federal government to pass further legislation. ${ }^{11}$ The Fugitive Slave Act of 1793, which resulted from the interstate dispute, stipulated that when a person held to labour in any of the United States, shall escape into any other of the said states or territory, the person to whom such labour or service may be due, his agent or attorney, is hereby empowered to seize or arrest such fugitive from labour, (b) and to take him or her before any judge of the circuit or district courts of the United States, residing or being within the state, or being any magistrate of a county, city or town corporate, wherein such seizure or arrest shall be made, and upon proof to the satisfaction of such judge or magistrate, either by oral testimony or affidavit taken before and certified by a magistrate of any such state or territory, that the person so seized or arrested, doth, under the laws of the state or territory from which he or she fled, owe service or labour to the person claiming him or her, it shall be the duty of such judge or magistrate to give a certificate thereof to such claimant, his agent or attorney, which shall be sufficient warrant for removing the said fugitive from labour, to the state or territory from which he or she fled. ${ }^{12}$

The newer statute addressed some of the glaring problems of the constitutional clause. Aggrieved slaveholders made their claims to "judge or magistrate," providing those officials with prima facie evidence of ownership, and outlined a process by which

\footnotetext{
${ }^{11}$ A dispute arose over the legal status of John Davis, an African-American. Virginia asserted that Davis was an escaped slave; conversely, Pennsylvania authorities argued that because proper registration of Davis as chattel had not occurred, he was by de facto emancipated in accordance with the gradual emancipation statutes. For a better summary of the controversy see Paul Finkelman's work, "The Kidnapping of John Davis and the Adoption of the Fugitive Slave Law of 1793," The Journal of Southern History, Volume 56, No. 3 (August, 1990), $397-422$.

12 "Respecting fugitives from justice, and persons escaping from the service of their masters," The Fugitive Slave Act of 1793; Statutes at Large, Chapter VII, pp. 302 (12 February 1793).
} 
lost chattel should be returned. The language of the latter statute implies a relatively simple process by which slaveholders recaptured their chattel. The whole process was much like reclaiming a lost dog or livestock; property rights were at the core of the matter. The chattel simply got away temporarily, and once found the property holder could re-secure their chattel at leisure.

Despite the efforts of Congress to rectify the dilemma of "fugitive(s) from labour," obstacles remained for slaveholders. The new fugitive slave law placed the burden of recapture upon the shoulders of the slaveholders. It made no mention of assistance from local, state, or federal authorities beyond obtaining a "sufficient warrant for removing said fugitive." ${ }^{.13}$ The process also depended upon the fact that the chattel was uncontested; not simply that another property holder claimed the chattel but rather that the chattel was not chattel at all but a free person of color. Similarly, the statute assumed that property holders or perhaps, more appropriately, hopeful property holders were honest in their claims. United States Supreme Court Justice Joseph Story, writing years later, commented on the shortcomings of both the constitutional clause and the Fugitive Slave Act of 1793: "There would seem to be the same necessity of requiring only prima facie proofs of ownership, without putting the party to formal assertion of his rights by suit at common law." 14 Furthermore, the 1793 statute allowed that an "agent" of the slaveholder could act in their stead opening the possibility that the agent may be unfamiliar with lost chattel in question. It was not out of the realm of possibility that agents could or would capture the wrong person or persons and confine them to the bonds

\footnotetext{
13 Ibid.

${ }^{14}$ Joseph Story, Commentaries on the Constitution of the United States (Boston: Hillard Gray and Company, 1833; reprint edition New York: De Capo Press, 1970), vol. III: 677 -678 .
} 
of slavery. A letter from a professional slave catcher near Philadelphia to a slaveholder in Maryland provides some evidence of the potential uncertainties in recapturing human chattel:

There is no doubt of this information being correct as I got it from Mr. Gallup's Mike some years since. Tom is of the description you gave and a fiddler and fond of liquor and idle, you may also wish to know my lowest terms for taking Tom. I have the same terms with all persons. I have one hundred and fifty dollars for taking a slave and the owner paying all expenses except the spy and the constable or one half they will bring in Maryland after our expenses are deducted out of sale. ${ }^{15}$

The contents of this letter are rather revealing. The description of Tom presented is rather vague at best. Perhaps the slave catcher received a more detailed description, which he did not reveal in his letter, but even then, there is some indication that he may have obtained the description of his quarry from still another party. These two considerations leave the possibility that the slave catcher might have the wrong person in his sights. Even further is his motivation in recapturing Tom; his stake has less to do with a financial loss and more to do with a financial gain. The sum of his fees indicates were he less than scrupulous he could make a small fortune kidnapping blacks and selling them into bondage outside of Pennsylvania. From the perspective of free blacks and subsequently the state of Pennsylvania, the prospect that an unscrupulous slaveholder, or slave catcher simply laying claim to their person on the street and taking them into bondage outside of the state threatened the personal liberties of free persons.

Accordingly, Pennsylvania recognized the need to protect the personal liberties of its citizenry as well as state sovereignty, so the state legislature passed statutes placing

\footnotetext{
${ }^{15}$ Undated letter to Mr. McClaskey, "Miscellaneous letters," Slavery - Runaway Papers, Harford County Historical Society; Bel Air, Maryland.
} 
further stipulations on recapturing slave chattel within the state. ${ }^{16}$ In 1826 , Pennsylvania passed An Act to give Effect to the Provisions of the Constitution of the United States, Relative to Fugitives from Labor, for the Protection of Free People of Color, and to Prevent Kidnapping. Legislators designed the Act to work concurrently with both the fugitive-from-labor clause of the Constitution and the Fugitive Slave Act of 1793. In short, the new legislation required slaveholders and their agents to provide more than prima facie evidence of property rights; thus, any attempt to circumvent Pennsylvania's legal hurdles could result in an indictment for kidnapping. ${ }^{17}$ The new anti-kidnapping legislation frequently thwarted slaveholders' ability to recapture their escaped chattel, so much so, that some Maryland slaveholders petitioned the federal government to intervene on their behalf. ${ }^{18}$ Effectively, then, by 1827 Pennsylvania provided some measure of political refuge from the oppression of slavery. Although entrance into the commonwealth did not in itself release enslaved blacks from bondage, the obstacles presented in the name of personal liberties at least delayed if not entirely dissuaded slaveholders from their efforts in recapturing lost chattel.

Beyond the safeguards of politics, geography added to the degree of refuge. If crossing Pennsylvania's southern boundary offered the opportunity for refuge, then where blacks settled within the commonwealth and when they settled there influenced their safety as much as any legislation. In the early $19^{\text {th }}$ century, northwestern Pennsylvania was still developing and largely removed from the influences of chattel

\footnotetext{
${ }^{16}$ Under Pennsylvania's original state constitution, free black men who owned property and/or paid taxes were citizens and eligible to vote in the commonwealth.

${ }^{17}$ Pennsylvania, 1840, "Affidavit - Prigg v. the Commonwealth of Pennsylvania" (Pennsylvania State Archives), 9.

${ }^{18}$ Memorial to the Senate and House of Representatives of the United States, 1838, Slavery - Runaway Papers, Harford County Historical Society; Bel Air, Maryland.
} 
slavery. Within the northwest corner of the commonwealth, Mercer County set the pace for population growth and development. For all intents and purposes Mercer was still very much part of the frontier in Pennsylvania. The Appalachian Mountains stood between Mercer and the larger populations in eastern Pennsylvania. Even Pittsburgh was more than a day's ride from Mercer and Erie was little more than a hamlet at the start of the $19^{\text {th }}$ century. Nevertheless, the region's persistent growth prompted Pennsylvania's General Assembly to carve Mercer from Allegheny County in 1800.

Its remote location dictated that the county's initial governmental offices were located in Meadville, to the north in Crawford County. Indeed, "in all practical matters, Mercer County was but an appendage to Crawford." ${ }^{, 19}$ It took officials another three years to organize the county's political infrastructure. From its inception, Mercer County was home to both free and enslaved blacks, though in relatively small numbers. According to federal census data, Mercer never had more than six enslaved blacks. ${ }^{20}$ Timothy Conoway and Robert Morgan, both men of color, appeared on the county's tax rolls in 1800; John Parks, John Stewart, and Joseph Alexander conversely appeared on those same lists of taxables as enslaved. ${ }^{21}$ The small black population directly coincided with the relatively small, but growing, population of the county in general, so that Mercer County offered a lot of land but few people in 1800 .

${ }^{19}$ History of Mercer County (Chicago: Brown, Runk, and Company Publishers, 1888), 141.

${ }^{20}$ The county's enslaved black population peaked in 1830. Abstract of the Returns of the Fifth Census, Showing the Number of Free People, the Number of Slaves, the Federal or Representative Number; and the Aggregate of Each County of Each State of the United States (Washington: Duff Green, 1832), 12

${ }^{21}$ History of Mercer County (1888), 147 - 150 and 154. 
The county's seemingly reluctant participation in the system of slavery had less to do with religious leanings or economics and more to do with its later settlement and subsequent development. The Society of Friends never gained any measurable influence in Mercer County, and while today the county is home to an industrious Amish population, in 1800 no such community existed. Many of Mercer's first residents were Scots-Irish Presbyterians who if given, the finances and the opportunity, would certainly have participated in slavery on a larger scale. Mercer County in 1800 was not ripe for the development of a plantation economy; the farming done within the county was small in scale and revolved largely around livestock -- sheep in particular. Because the county was officially, formed twenty years after the commonwealth's gradual emancipation act, and because of its remote and rural location large-scale chattel slavery never had a chance to development in Mercer. ${ }^{22}$ Although slavery never put down deep roots in the county, the same was not true of the antislavery movement. Abolitionists were active in the county in the first half of the century, advertisements for "Anti-Slavery Lectures," "AntiSlavery Meetings," and even an "Anti Slavery Convention" appeared regularly in the local newspapers. ${ }^{23}$ By 1850, in Millbrook, Mercer County antislavery meetings took place on a monthly basis and continued with the same regularity until Lincoln issued the Emancipation Proclamation. According to one county resident, "Millbrook was the hub or hotbed of anti-slavery."24

22 Ibid., 137 and 147.

${ }^{23}$ Mercer Luminary, 1 December 1847 and 8 March, 16 February, 12 July 1848.

${ }^{24}$ John Hogue to Wilbur Siebert, 1895 and "Wesley Hogue," by his son, Wilbur H. Siebert Collection, Microfilm Edition (MIC 192, Roll 13) Ohio Historical Society, Columbus. 
In 1837, five men took out an ad in the local Mercer newspaper, The Western Press, looking for 3800 acres of land. The five men, William Barnes, Samuel Johnson, Doctor Sloan, George Doctor, and Adam Holmes hoped to purchase a tract in the county, "for the purpose of establishing a colony of free colored persons." They further believed that, "this shows that the colored population feel themselves able to support each other without the aid of abolitionists." ${ }^{25}$ This was not the first proposed black communal settlement in Pennsylvania nor was it the last. A year earlier, Robert Rose a wealthy white philanthropist from Susquehanna County proposed a settlement for free blacks near Silver Lake. ${ }^{26}$ In large part, white philanthropists initiated both of these efforts, purporting to know and understand the best interests of black refugees. The condescension of whites, in retrospect, seems almost comical. More than a few blacks had already proved that they could support themselves through their own efforts by this time. The nineteenth-century notions of race clearly influenced the degree of support offered by whites, and on some level implied that assistance came with strings attached. If, however, the philanthropic designs of the Mercer five ever took root, they did so outside of Mercer County. No records exist to indicate whether they ever secured the desired acreage or even of they began a black communal settlement within the county.

This is not to suggest that black settlement efforts never took root in Mercer County. On the contrary, the county was home to settlement efforts other than ones inspired and funded by white philanthropists. Even before the Mercer five took out their ad in the Western Press, Richard Travis, a free person of color purchased land in 1818 to

\footnotetext{
${ }^{25}$ Western Press, 9 December 1837.

${ }^{26}$ William H. and Jane Pease, Black Utopia: Negro Communal Experiments in America (Madison: The State Historical Society of Wisconsin, 1963), $41-42$.
} 
begin a community for black refugees. Between 1820 and 1830, a small black community began to emerge in Mercer County, along the shores of Sandy Lake. Within the confines of the county, blacks were conspicuous in their presence in 1820. Despite their presence among the county's original settlers, the total black population for Mercer County in 1820 was less than one hundred persons. That same year the county's white community dwarfed the black population by several thousand; Mercer's black population accounted for less than one percent of the total population. ${ }^{27}$ The southern half of the county was home to the heaviest total population concentration; Mahoning, Neshannock, and Slippery Townships were the most populous in the county. Although the majority of the county's total population was southerly in its orientation, the same did not hold true for blacks. In fact, the largest black populations were in two northwestern townships, West Salem and Pymatuning. ${ }^{28}$

A few other blacks called the eastern half of the county home. In 1820, Coolspring and Sandy Lake Townships had a combined black population of eight individuals. Ten years later the combined population swelled to 88 blacks. By 1830, the black population more than doubled and its spatial distribution shifted dramatically from the northwest corner to the eastern townships. West Salem's black population grew by one individual over the course of the decade, while Pymatuning actually decreased by two. ${ }^{29}$ Although the black population continued to grow steadily in Mercer County until mid-century, it never constituted anywhere near a majority of the total population.

\footnotetext{
${ }^{27}$ The total population for Mercer County, PA in 1820 was 11681; with only 91 African Americans the black population amounted to just less than eight tenths of a percent (.0077904). Census for 1820 (Washington: Gales and Seaton, 1821), 76.

${ }^{28}$ Ibid.

${ }^{29}$ Ibid., Abstract of the Returns of the Fifth Census, 12.
} 
Further, despite the presence of some blacks in the borough of Mercer itself, the preponderance of the black population remained on the edges of the major towns and confined to the more rural parts of the county. ${ }^{30}$

The residential shift in the black population was not happenstance. The emerging community along Sandy Lake began in 1818 with the sale of land to Richard Travis; he purchased one hundred fifty acres from Stephen Barlow and Henry Baldwin. Neither Barlow nor Baldwin was native to Mercer County, and Barlow at least worked as agent for the American Land Company, a land speculation firm. Travis paid the princely sum of two dollars for the land. Three years later Baldwin and Barlow sold an additional two hundred eighteen acres to Travis for a little more than four hundred dollars. ${ }^{31}$ By 1821, Richard Travis and his wife lived on 368 acres of their own land. If Travis had grand designs to turn his estate into a thriving farming enterprise he left no mention; clearly however he did have some plans for all of the land he owned. In 1823, he began selling off parcels of his estate; John Travis paid fifty dollars for the "undivided half part of one hundred twenty three acres being known as the settlers part on which the said Richard Travis and Lucinda, his wife now lives. ${ }^{, 32}$ The exact relationship between the two Travises remains uncertain, but it appears that John was probably the brother of Richard Travis. In either case, this was the start of a black settlement on the shores of Sandy Lake

\footnotetext{
30 Ibid.

${ }^{31}$ The American Land Company gained greater prominence after the American Civil War, through the speculation and selling of southern lands to new freemen and their families. Mercer County Deed Book E1, 412 - 413 and Mercer County Deed Book P1, 326 - 327, County of Mercer Recorders Office; Mercer, Pennsylvania.

${ }^{32}$ Mercer County Deed Book G1, 363, County of Mercer Recorders Office; Mercer, Pennsylvania.
} 
called Liberia. Very quickly, the settlement prospered and drew more and more black refugees to the area. ${ }^{33}$

Travis's efforts exceeded simply providing land and opportunity for those in need; by 1830 , Liberia became an important stop on the Underground Railroad. ${ }^{34}$ According to James Lawson, another Liberian resident and Travis's grandson, Liberians routed black refugees on the Underground Railroad around the eastern side of Sandy Lake. ${ }^{35}$ Essentially three lines of the Underground Railroad ran through Mercer County, linking it with Washington County in the southwestern portion of the state and Erie County in the far northwestern corner of Pennsylvania. Through the Underground Railroad, refugees from outside of Pennsylvania found refuge that had frequently eluded them.

The road to freedom in and through Liberia was not an easy path. In terms of structure, the Underground Railroad in western Pennsylvania resembled a tree; black refugees entering the region came in through Washington County providing the roots (routes) of the railroad in the western half of the state. From Washington, persons sympathetic to the refugees' plight passed them along to Pittsburgh. William Mason recalled that the journeys from Washington to Pittsburgh "were always dangerous." ${ }^{36}$ At Pittsburgh, the lines diffused again, moving westward into Ohio and northward to

\footnotetext{
33 "Wesley Hogue," by Unidentified Son, Wilbur H. Siebert Collection, Microfilm Edition (MIC 192, Roll 13) Ohio Historical Society, Columbus.

${ }^{34}$ Letter to Wilbur Siebert from the son of Wesley Hogue, Wilbur H. Siebert Collection, Microfilm Edition (MIC 192, Roll 13) Ohio Historical Society, Columbus.

${ }^{35}$ James Lawson to Wilbur Siebert, 22 April 1896, Wilbur H. Siebert Collection, Microfilm Edition (MIC 192, Roll 13) Ohio Historical Society, Columbus.

${ }^{36}$ William Mason, "Romances and Realities of the Underground Railroad," Johnson's Lake Shore Home Magazine, Volume III, No. 8, (August 1887), Wilbur H. Siebert Collection, Microfilm Edition (MIC 192, Roll 13) Ohio Historical Society, Columbus.
} 
Beaver, New Castle, and Mercer. At Liberia in Mercer County, the Underground Railroad linked stations to both the North and West. Travis himself carried many black refugees on to Ohio and passed them along to Joshua Giddings. ${ }^{37}$ Doc Brown who owned the tavern along the lake brought many of the settlers as well as others from the more southerly parts of Mercer County through to Sandy Lake. ${ }^{38}$

The diffusion of the lines inhibited the pursuit efforts of some, though not all, slave catchers. Abel Boguess, a black refugee from Virginia, entered Pennsylvania and traveled along the Underground Railroad line through Pittsburgh into New Castle in Mercer County. Along the road, Boguess sent word of his travels back to friends and family in Hardy County, Virginia. Apparently concerned about his kin back in Virginia, Boguess unwittingly jeopardized his newly acquired freedom by attempting to contact them. He was shocked to discover that slave catchers also got word of his arrival in Pennsylvania, and were tracking him. On a visit to see abolitionist Sam Marshall in Butler, Pennsylvania Boguess came face to face with his pursuers. Fortunately, for Abel Boguess, he was not traveling alone and his friends alerted nearby abolitionists. Boguess fled into the woods and his friends confronted the slave catchers with shotguns. ${ }^{39}$

Boguess survived this harrowing experience, but his narrow escape demonstrated the inherent dangers of black refugees' flight from bondage to freedom. Liberian settler Auntie Strange was not as fortunate. Before her arrival in Liberia, she made at least two

\footnotetext{
${ }^{37}$ Letter to Wilbur Siebert from James Lawson, 22 April 1896, Wilbur H. Siebert Collection, Microfilm Edition (MIC 192, Roll 13) Ohio Historical Society, Columbus. ${ }^{38}$ Letter to Wilbur Siebert from Unidentified, 25 November 1895, Greenville, PA, Wilbur H. Siebert Collection, Microfilm Edition (MIC 192, Roll 13) Ohio Historical Society, Columbus.

${ }^{39}$ Abel Boguess (aka James Garlick), interview by Wilbur Siebert, 9 August 1892, Wilbur H. Siebert Collection, Microfilm Edition (MIC 192, Roll 13) Ohio Historical Society, Columbus.
} 
previous attempts to escape from bondage. On both occasions, slave catchers captured her and returned her to bondage. As payment for her efforts, either her slaveholders, or their agents, cut off her fingers at the knuckles. ${ }^{40}$ Her perseverance brought her to freedom, but her previous unsuccessful attempts indicate that trial and error probably also played a part in her success. Auntie Strange was not alone in her trials and tribulations; another black refugee in Mercer County arrived from Georgia where he too had made previous attempts at escape, and just like Auntie Strange, slaveholders punished him for his efforts. "To prevent any further attempts at escape [slaveholders] had put a chain and ball on his leg, and compelled him to work in that condition," the ball and chain cut deeply into his leg and left him scarred for life in more ways than one. ${ }^{41}$

Whether singularly or in groups, escorting black refugees through western Pennsylvania required equal measures of luck, timing, and sound planning; abolitionists in Mercer were wary of the dangers along the routes, and took great precautions. One abolitionist in Mercer County "had a man on the route a day ahead of his train to find out where to stop, and what dangers were before him., ${ }^{, 42}$ With some exceptions, most black refugees traveling into and through Mercer County traveled at night to avoid detection, during the day they secured a hiding place and rested until the following night. ${ }^{43}$ Black refugees traveling alone found it easier to move quickly at night and hide by day; they

\footnotetext{
${ }^{40}$ Wesley Hogue to Wilbur Siebert, Wilbur H. Siebert Collection, Microfilm Edition (MIC 192, Roll 13) Ohio Historical Society, Columbus; “Auntie Strange," The Sharon Herald, 9 February 1960.

${ }^{41}$ Joseph White to Wilbur Siebert, 23 March 1893, Wilbur H. Siebert Collection, Microfilm Edition (MIC 192, Roll 13) Ohio Historical Society, Columbus.

${ }^{42}$ Moses Reeder to Wilbur Siebert, 11 February 1897, Wilbur H. Siebert Collection, Microfilm Edition (MIC 192, Roll 13) Ohio Historical Society, Columbus.

${ }^{43}$ Joseph White to Wilbur Siebert, 23 March 1891 and John F. Hogue to Wilbur Siebert, 6 September 1892, Wilbur H. Siebert Collection, Microfilm Edition (MIC 192, Roll 13) Ohio Historical Society, Columbus.
} 
had only themselves about whom to worry. On the route through Mercer, most refugees "did not usually travel in squads but rather single individuals."

Larger groups, more rare but not unknown, required that abolitionists work in greater concert with one another and the refugees themselves to keep them safe from recapture. Near Liberia, the Hogue family received "two men and their wives ... and one boy and an infant. They were unloaded at ten o'clock and hurried into a room. They stayed the next day," at which point Mr. Hogue "started out amongst the anti-slavery people to raise money to pay their boat fare across the lakes." ${ }^{25}$ The presence of children, old and infirmed refugees only added to the difficulties and frequently slowed refugees down. Children, particularly young children, required greater assistance and attention than did their adult counterparts. Many were too young to understand the magnitude of their flight from bondage, and were less able to endure even the more the common hardships of the journey. One refugee explained to those assisting her in Mercer that, "when the children wanted a drink of water, as a substitute for a cup, [she] would pull off a shoe and dip up the water for them.."46

Although many white abolitionists took great precautions in assisting black refugees, not all of the refugees depended upon them in flight, E.M. Stevenson remembered that as a young man "Mr. Walker and Mr. Anderson brought three big burly Negroes here [Mercer]. They were armed to the teeth with bowie knives and pistols; they

\footnotetext{
${ }^{44}$ Letter to Wilbur Siebert from Unidentified, 25 November 1895, Wilbur H. Siebert Collection, Microfilm Edition (MIC 192, Roll 13) Ohio Historical Society, Columbus.

${ }^{45}$ John F. Hogue to Wilbur Siebert, 6 September 1892.

${ }^{46}$ Joseph White to Wilbur Siebert, 23 March 1891.
} 
said they would resist arrest until death." 47 The three "burly" refugees were fortunate enough to secure firearms, and coupled with their size were probably a daunting sight for would be pursuers. Other blacks relied upon their numbers and whatever makeshift weapons they could secure. On a separate occasion, slave catchers closely pursued and overtook ten black refugees in Mercer County but the blacks "were not altogether taken by surprise." Instead, they "made resistance with clubs, corncutters, etc.," and fought off their pursuers. ${ }^{48}$ Although their weapons were not as formidable as pistols or other firearms, these black refugees found safety in numbers. The fact that there were ten of them meant their pursuers needed more than a few in their own party to secure the refugees. The names and experiences of the three burly refugees and the ten armed with farming implements are unknown, but their experiences in bondage may have been severe enough to view death as more viable option than a return to bondage. Considering the punishments suffered by Auntie Strange and her Georgia counterpart, resistance meant preventing not only a return to bondage but also any harsh punitive punishments that coincided with capture. Still others relied more on strength of mind and deception, rather than force of arms. One black refugee who passed through Liberia, William Edwards, escaped by assuming an alias and paid for a copy of a deceased slaveholder's will, which freed the decendent's chattel. Edward's ruse worked as he successfully

\footnotetext{
${ }^{47}$ E.M. Stevenson to Wilbur Siebert, 24 February 1897, Wilbur H. Siebert Collection, Microfilm Edition (MIC 192, Roll 13) Ohio Historical Society, Columbus.

${ }^{48}$ Joseph White to Wilbur Siebert, 23 March 1893 and January 1897, Wilbur H. Siebert Collection, Microfilm Edition (MIC 192, Roll 13) Ohio Historical Society, Columbus.
} 
escaped bondage in October of 1848; by 1851 , he made his way on to Canada after an interlude in Mercer County. ${ }^{49}$

For other black refugees moving through Mercer County, abolitionists offered more than superficial assistance; in some cases, they offered a new home. On at least one occasion, a local abolition group "raised the money to buy [an] acre of land," for Uncle Jesse Richards. "Two days later [they] raised him a cabin," and provided "a stove and . . . the pipe and in less than a week the house was shingled." ${ }^{50}$ Doc Jimmy Brown, who owned 640 acres immediately adjacent to Liberia, opened his doors to a pregnant refugee and presumably offered some medical assistance as well. Brown purchased at least two of his 640 acres from Richard Travis and his wife in $1836 .{ }^{51}$ Doc Brown also owned and operated a tavern near Sandy Lake. The tavern allowed Brown to monitor travelers in the area, and perhaps tipped off his Liberian neighbors when those travelers were slave catchers. ${ }^{52}$ Help from neighboring whites certainly added to the black refugees' chances for success, but of greater value than the pecuniary assistance, Liberia offered a measure of anonymity. In Liberia, where both free and refugee blacks lived side-by-side, slave catchers had difficulty discerning who was who. Whether the refugees stayed on in

\footnotetext{
${ }^{49}$ Dr. William Edwards to Wilbur Siebert, 3 August 1895, Wilbur H. Siebert Collection, Microfilm Edition (MIC 192, Roll 13) Ohio Historical Society, Columbus.

${ }^{50}$ John Hogue to Wilbur Siebert, 1895, Wilbur H. Siebert Collection, Microfilm Edition (MIC 192, Roll 13) Ohio Historical Society, Columbus.

${ }^{51}$ Brown purchased a total of 208 acres from Travis for $\$ 500$ in two transactions dated 23 January 1836 and 29 April 1836. Mercer County Deed Books, P1, 326 - 329, County of Mercer Recorders Office; Mercer, Pennsylvania.

52 Joseph Polk, Interview by William Hunter, 25 May 1946, Folder \#8, "Negro Settlement," William Hunter Collection; Mercer County Historical Society, Mercer, PA and Unidentified letter to Wilbur Siebert, 25 November 1895, Wilbur H. Siebert Collection, Microfilm Edition (MIC 192, Roll 13) Ohio Historical Society, Columbus.
} 
Liberia, as many apparently did, or chose to keep moving north towards Canada, the makeup of the community itself aided the efforts of black refugees to find freedom.

Richard Travis's hope for a community of refuge depended, in no small part, on secrecy. Despite the remote location of their settlement, those who fled from bondage were not entirely out of the reach slaveholders and their agents. Consequently, it should come as little surprise that Liberia does not appear on maps of the period. The ability of black settlers to maintain a low profile kept members of the community safe but also served a greater purpose.

The black settlers who arrived at Liberia were a mix of free blacks, emancipated blacks, and blacks recently escaped from bondage. ${ }^{53}$ Unlike the independent designs of the proposed 1837 community, Liberia looked for at least some assistance from nearby whites as well as Native Americans; the diverse backgrounds of the Liberia settlers dictated some measure of assistance. The degree of that assistance varied, depending upon who offered the assistance. Liberian neighbor and abolitionist, Doc Brown, for example, not only provided shelter to black refugees, actively assisting when necessary, but also he later donated land for the Liberians to use as a cemetery. White abolitionists were not the only neighbors able to assist Liberia, a local Native American community offered assistance as well. The nearby Native Americans seemed less concerned with philanthropic endeavors and instead preferring ventures that were more economically oriented. They traded with the Liberians frequently providing them with salt, a vital

\footnotetext{
${ }^{53}$ Unidentified Letter to Wilbur Siebert, 25 November 1895, Wilbur H. Siebert Collection, Microfilm Edition (MIC 192, Roll 13) Ohio Historical Society, Columbus.
} 
commodity on the frontier. On at least one occasion, the local Native American

population also provided medical assistance to the Liberians. ${ }^{54}$

In many ways, Liberia was a community of persons dependent upon some kind of assistance. Blacks who had gained freedom through Pennsylvania's gradual emancipation act found opportunity and the chance at a new life in Liberia; community members like Pompey Whiting arrived newly emancipated after years of bondage. ${ }^{55}$ Fate did not simply bring the Liberians together; they congregated in Mercer County because of its potential. The primary source of the county's attraction was the abundant and relatively inexpensive land, a commodity many blacks did not have access to prior to their arrival in Liberia. Richard Travis either sold or gave land to fellow blacks to live on and farm; his example set the tone for the development of Liberia.

Through the efforts of Richard Travis, neighboring abolitionists, and local Native Americans, Liberia grew rapidly in the first half of the nineteenth-century. Cool Spring and Sandy Lake Townships went from black populations of none and eight respectively, in 1820 , to forty-one and forty-seven in 1830; Liberia was located within Cool Spring. ${ }^{56}$ In measuring the growth of Liberia, even those numbers are deceptive. Because the

\footnotetext{
${ }^{54} \mathrm{Mr}$. Polk was the grandson of some of the early settlers in Liberia. He reported that on at least one occasion an "Ojibway" (sic), provided medical care to his father Samuel. Transcript of "Interview with Mr. Joseph Polk, Stoneboro," interview by William Hunter, 25 May 1946, Folder \#8, "Negro Settlement," William Hunter Collection; Mercer County Historical Society, Mercer, PA.

${ }^{55}$ Pompey Whiting appeared in Mercer County for the first time in 1830 as a free black man. His name indicates that he was probably enslaved at some point in his life, perhaps by whites in Mercer County, as several Whitings are listed on the tax rosters in 1800. Abstract of the Returns of the Fifth Census, Showing the Number of Free People, the Number of Slaves, the Federal or Representative Number; and the Aggregate of Each County of Each State of the United States, (Washington: Duff Green, 1832) and History of Mercer County (1888), 149.

${ }^{56}$ Census of 1820, 76 and Abstract of the Fifth Census, 12.
} 
community was comprised of both free blacks and black refugees, not everyone wished to have the census takers enumerate them. At the turn of the decade, Mercer County's black population had grown to 201 free persons of color and 6 slaves; but persons like Auntie Strange and the unidentified Georgian were not likely to appear on the rolls of the federal census. Consequently, it is difficult to ascertain just how large of a community Liberia was. Although there was no official enumeration of Liberia's residents, neighbors to the community reported that at its largest, Liberia was home to "several hundred," residents. By 1840 , the total free black population in Mercer County numbered only 328, so if Liberia's neighbors were even close in their count then Liberia alone was at least two-thirds the size of the free black population. ${ }^{57}$

As Liberia grew, clusters of clapboarded houses and some rather extensive farms dotted the area around Sandy Lake. ${ }^{58}$ Farming dominated Mercer County in 1840. Roughly seven thousand residents of the county were engaged in agricultural pursuits. ${ }^{59}$ Their farms kept Liberians on par with their neighbors, although for Liberians farming also assisted the efforts to remain discreet while at the same time, taking advantage of the agricultural backgrounds of many formerly enslaved blacks. Unfortunately, neighboring whites only commented on how extensive Liberian farms were, not on any particular crop or on the measure of success achieved by the Liberian farmers. The rather nondescript

\footnotetext{
57 "Wesley Hogue," by Unidentified Son, Wilbur H. Siebert Collection, Microfilm Edition (MIC 192, Roll 13) Ohio Historical Society, Columbus; Abstract of the Fifth Census, 12; Compendium of the Enumeration of the Inhabitants and Statistics of the United States, as Obtained at the Department of State, From the Returns of the Sixth Census, (Washington: Thomas Allen, 1841), $142-144$.

${ }^{58}$ Joseph Polk, Interview by Mairy Jayne Woge, "Liberia - Now Stoneboro - Was Slaves' Refuge," The Sharon Herald, 1965. Unidentified Letter to Wilbur Siebert, 25 November 1895, Wilbur H. Siebert Collection, Microfilm Edition (MIC 192, Roll 13) Ohio Historical Society, Columbus.

${ }^{59}$ Compendium of the Sixth Census, $142-144$.
} 
account of the farms indicates that aside from their complexion little distinguished the Liberians. Likewise no records exist to indicate that the Liberians were engaged in any skilled labors or crafts, again providing no differentiation that might draw attention to their community. Because farming required little skill or previous work experience, the black refugees who arrived in Liberia were probably better suited to farming than anything else. Furthermore, skilled artisan occupations frequently required capital to purchase tools with which to practice the trade. As former bonds-people, capital was certainly lacking, as they owned little more than the clothes on their backs. Still other factors contributed to the development of Liberia as a farming community, aside from those refugees who passed through quickly, many stayed for days, sometimes weeks before moving on, and still others felt compelled to stay and establish new homes. For those who spent any length of time in Liberia there was little else to do but farm, and their labors would certainly have contributed to the extensiveness of Liberia's farms.

Even with the farming successes of its settlers, Liberia remained a largely segregated community. On some level, then, the Liberians must have felt marginalized, living collectively alongside Native Americans on the fringe of Mercer County. The marginalization of refugee communities is not unusual; on the contrary, this is more often the norm. However, in many refugee situations, the refugees are typically isolated and marginalized due to language or other cultural barriers. In the case of Liberia however, what set them apart from the larger community was the same thing that set them apart as potential slaves - race. The segregated county was counter productive for Liberia for 
several reasons; in refugee communities isolation leads to a sense of dependency. ${ }^{60}$ For the black refugees of Liberia that dependency was directed less toward any particular aid agency, but instead toward a geography that facilitated anonymity. Necessity dictated their discretion and suspicion of unfamiliar faces, but also kept them isolated from the whole of Mercer County. Despite assistance from neighboring whites, Liberia remained a self-contained community.

Even as Liberia increased in population, Liberians seemed to be of little interest to most whites in Mercer County. The Liberian settlers were conspicuous in their absence from everyday life in the county; local newspapers gave no indication that any community existed along Sandy Lake. The blacks remained segregated geographically and nearly invisible socially. If neighboring whites knew of the Liberian settlement most made no mention of it. In the historiography of black settlement efforts, historians have debated the extent of this segregation, and its causes. Robin Winks suggested that blacks themselves were culpable for the patterns of segregation in the settlements. More recently, Harvey Whitfield pointed out that Winks' suppositions "ignored examples of agency and initiative." ${ }^{61}$ In the case of Liberia, its settlers may have had some selfimposed segregation, but that segregation was born of circumstance rather than any overt planning. Their need and desire to remain anonymous helped protect their freedom from physical bondage. Those needs and desires, however, enslaved Liberia's black refugees

\footnotetext{
${ }^{60}$ Barry Stein, "The Refugee Experience: Defining the Parameters of a Field Study," International Migration Review, Vol. 15, No. 1/2, Refugees Today, (Spring - Summer, 1981), pp. 324.

${ }^{61}$ Harvey Amani Whitfield, “' 'We Can Do As We Like Here' : An Analysis of Self Assertion and Agency Among Black Refugees in Halifax, Nova Scotia, 1813 - 1821," Acadiensis, XXXII, 1 (Autumn 2002), 30.; Robin Winks, The Blacks in Canada (New Haven, 1971), $114-141$.
} 
just as surely as their arrival in Pennsylvania promised to free them. Their need to remain obscure prohibited them from obtaining any measure of great success, lest that success draw unwanted attention to them and consequently draw the attention of slaveholders and their agents.

The need for secrecy and anonymity left stunted economic and social structures in Liberia. Anything Liberians could not produce by their own labors, they had to secure from friendly neighboring white communities. Although a community of several hundred, Liberia lacked much of the civic culture found in the neighboring white communities. There are no records of schools, churches, or newspapers. Similarly, nothing exists to suggest any measure of industry - no mills, furnaces, blacksmiths, or even farriers. It is possible that, within Liberia, some had previous blacksmithing experience and provided the service to the community; more than a few enslaved blacks learned the blacksmithing trade. That same blacksmith could probably do the work of any farrier as well, shoeing whatever horses were present in the community. Beyond what a blacksmith could provide, there was probably little need for any furnaces. A furnace was essential for industrial and commercial enterprises, but since the Liberians relied principally upon what they produced on their farms, a furnace was a luxury they could ill afford. Furthermore, a furnace would draw the kind of attention Liberians wanted to avoid. Mills, like furnaces, were commercial enterprises that drew people from the surrounding countryside, and this was the kind of attention Liberians resisted. Because it is difficult to ascertain how many of the people in Liberia were permanent residents and how many were transients, schools may have proved unnecessary. If transients dominated the population, any schooling was pointless as students would have 
come and gone in relatively short order without acquiring any substantial schooling.

Likewise, newspapers would have proven equally pointless in a community dominated by transients. They had little knowledge of the surrounding area, so what material newspapers had to offer would have been of no consequence to them.

For every degree of self-sufficiency Liberia attained the community reinforced an equal measure of segregation and marginalization. It is unfair to say however, that the Liberians alone defined the degree of segregation and marginalization within Mercer County. The black refugees who came to and settled in Liberia had few choices. They did not have the freedom or the means to settle anywhere they chose. Obviously, they could not achieve the measure of freedom they desired south of the Mason and Dixon Line, and even states that had abolished slavery provided them meager options. State legislation could regulate whether to maintain or abolish chattel slavery, but the same codes could not regulate the attitudes, which defined race and class. Not all communities were receptive to immigration of black refugees; ironically, in Mercer County, Ohio whites prevented more than three hundred black refugees from settling there through threat of violence. ${ }^{62}$

Liberia's white neighbors, by way of contrast, did have many more choices in where they settled, and their recollections of Liberia are very telling. This was an exclusively black settlement. Aside from a few white neighbors, like Doc Brown, there were no whites. When neighboring whites spoke of Liberia, it was in the context of social binaries, "we" and "they." Although there are no records indicating that state or local codes marginalized the Liberians, whites set the terms and the boundaries for any

${ }^{62}$ Frank F. Mathias, "John Randolph's Freedmen: The Thwarting of a Will,” The Journal of Southern History, Vol. 39, No. 2 (May, 1973), 263-272. 
contact between themselves and the settlers in Liberia. The majority of whites in the area probably knew Liberia existed, but they had little reason to visit or conduct business with the black community. To that end, the local whites' attitude toward Liberia and its inhabitants could best be characterized as generally apathetic.

By 1840, what had begun in 1818 as Richard Travis's efforts to create a community of refuge for both free blacks and black refugees, was now a thriving community of several hundred people. To that end Liberia was a success, but that success came at a price; Liberians increasingly segregated themselves with few objections from the neighboring white communities of Mercer County. The transient refugees had crossed the Mason and Dixon Line in search of freedom from bondage. For some Liberia was probably as close to paradise as they had ever known; a tight knit, exclusively black community, which relied on self-sufficiency rather than the philanthropy of white abolitionists who did not always view blacks as equals. Success nourished hope for greater freedoms, and the efforts of people like Richard Travis continued to draw more black refugees into the community if only for brief periods of time. By 1850 , however, this thriving community had grown at such a fantastic pace it was hard for Liberia to go unnoticed to slaveholders in search of lost chattel. ${ }^{63}$ Liberia's success as a refuge became its undoing, within a year the exclusively black community of extensive farms was gone.

\footnotetext{
${ }^{63}$ Between 1820 and 1850, the two townships along Sandy Lake witnessed an $1100 \%$ growth in black population, even as the total population for Mercer County grew by only 284\%, Census of 1820, 76 and Statistical View of the United States, Embracing Its Territory, Population - White, Free Colored, and Slave - Moral and Social Condition, Industry, Property, and Revenue; the Detailed Statistics of Cities, Towns and Counties; Being a Compendium of the Seventh Census (Washington: Beverly Tucker, 1854), 154 157.
} 


\section{CHAPTER 3}

\section{UNCOVERED PARTRIDGES}

I worked there till the fugitive slave bill came out. Then I couldn't stay there. I felt like and uncovered partridge that a hawk was after. Bushes had all gone away and left the partridge, so I couldn't stay there. ${ }^{1}$

- Dr. William Edwards

In 1818 , the small community of Liberia began on the shores of Sandy Lake in Mercer County, Pennsylvania. The name of the community was indicative of the hopes the settlers had for themselves, their future, and their new community. Liberia was a mixture of free blacks and black refugees, some in flight and others at the end of their journey. Their collective efforts cultivated the freedom and liberty they so eagerly sought. By 1840, the little village numbered perhaps into the hundreds, although an accurate number is difficult to gauge because of the transient status of some and the need for secrecy of others. Despite the refuge provided by Liberia's remote location in rural northwestern Pennsylvania, threats remained to black refugees' freedom. For Liberians, their freedom required greater maintenance than their new farms. Slaveholders were not eager to relinquish their claims on enslaved chattel. Slaveholders and their agents often pursued black refugees north, and, though not always successful, they remained a constant threat. But, slaveholders themselves were not the only threats to Liberians' freedom. Just as many found comfort and refuge in their new community, events conspired locally, statewide, and nationally to eradicate their refuge Liberia.

Even as Liberia grew so too did the rest of Mercer County. In 1830, the county was the most populous in the northwest corner of the state and the $13^{\text {th }}$ largest of the 32

\footnotetext{
${ }^{1}$ Dr. William Edwards to Wilbur Siebert, 3 August 1895, Wilbur H. Siebert Collection, Microfilm Edition (MIC 192, Roll 13) Ohio Historical Society, Columbus.
} 
counties west of the Allegheny Mountains. ${ }^{2}$ By mid-century new industries took root in the largely agrarian county, prompting a local newspaper to report, "That the light of ten furnaces could be seen from the cupola of the courthouse." 3 With the growth in the county, entrepreneurs saw opportunities for financial growth; consequently, they invested more than $\$ 66,000$ in manufacturing in the Mercer by $1840 .{ }^{4}$ All of the growth necessitated better access to Mercer County and its residents. If commercial access failed to keep pace with the county's growth, economic development would surely cease, as would any future growth.

Mercer's remote location in the northwest corner of the state posed problems to commercial traffic; its distance from major navigable water routes and turnpikes limited commercial traffic to overland shipping. State legislators and local authorities recognized the need for improvements in the infrastructure and explored ways to expand access to and from Mercer County. In 1835, Governor Joseph Ritner proposed a canal linking the Ohio River and Lake Erie, via Mercer County. If successful, the canal would provide quicker access to the rapidly growing county. ${ }^{5}$ Not long after the governor's proposal, the canal project faced perhaps its most daunting obstacle. Before crews could complete any work on the canal, Democrats replaced Ritner and his Anti-Masonic supporters, and nullified all state contracts. This major setback threatened to end the project before it

\footnotetext{
${ }^{2}$ Abstract of the Returns of the Fifth Census, Showing the Number of Number of Free People, the Number of Slaves, the Federal or Representative Number; and the Aggregate of Each County of Each State of the United States, (Washington: Duff Green, 1832), 12 -13 .

${ }^{3}$ Western Press, 13 November 1846.

${ }^{4}$ Compendium of the Enumeration of the Inhabitants and Statistics of the United States, as Obtained at the Department of State, From the Returns of the Sixth Census, (Washington: Thomas Allen, 1841), 142 - 144.

${ }^{5}$ History of Mercer County Pennsylvania, (Philadelphia: L.H. Everts and Company, 1877), 21.
} 
even started, but ultimately failed to thwart the economic development in northwestern Pennsylvania. Without the financial support from the state legislature, private investors picked up the slack and chartered the Erie Canal Company. The investors' desire to secure better access to the northwest was such that the brief transition from public to private funding barely caused a hiccup in the completion of the canal. By 1844, the Erie Canal Company completed the work and opened the canal to commercial traffic. ${ }^{6}$

Although the canal provided greater access to Mercer County and supported the growth of industry, it best served agriculture. "Manufactures and trades," gained greater importance in the growth of the county, but remained secondary employers to agriculture. At mid-century, Mercer County's farms were collectively valued at nearly five million dollars; with a significant amount of money invested in livestock. ${ }^{7}$ Mercer trailed only Washington and Allegheny Counties in the production of wool in the state. But the county's sheep were not the only avenue of agricultural production; Mercer was also a leader in buckwheat and flax in Pennsylvania. ${ }^{8}$ Where Liberia fit into the agricultural well being of the county is difficult to say, since they left no records of their own and their white neighbors simply reported that the Liberians, "owned quite extensive farms." The same neighbors failed to define just what they meant when they described the

\footnotetext{
${ }^{6}$ History of Mercer County Pennsylvania, (1877), 21; Eric Ledell Smith, "The End of Black Voting Rights in Pennsylvania: African Americans and the Pennsylvania Constitutional Convention of 1837 - 1838," Pennsylvania History, 65 (Summer 1998), 284.

${ }^{7}$ Livestock in Mercer County was valued at $\$ 846,511$ in the 1850 Census. Statistical View of the United States, Embracing its Territory, Population - White, Free Colored, and Slave - Moral and Social Condition, Industry, Property and Revenue; The Detailed Statistics of Cities, Towns and Counties; Being a Compendium of the Seventh Census, (Washington: Beverly Tucker, 1854), 298.

${ }^{8}$ Compendium of the Sixth Census, 143 - 144.

${ }^{9}$ Unidentified letter to Wilbur Siebert, 25 November 1895, Wilbur H. Siebert Collection, Microfilm Edition (MIC 192, Roll 13) Ohio Historical Society, Columbus.
} 
Liberian farms as extensive. Were they extensive in numbers and land? Or, were the farms extensive because of the diversity of produce and livestock Liberians raised? The existing records fail to answer those questions. However, the refugee status of many of the Liberian settlers allows scholars to draw some reasonable conclusions. Because many Liberians were refugees from slavery, their status suggests they had limited access to capital, and did not bring much, if anything, in the way of farm tools.

Black refugees' ability to acquire tools and livestock depended upon the assistance of others. Fred Landon's research on black refugees in Upper Canada demonstrates as much. The Buxton refugee settlement in Upper Canada consisted of 130 families with 520 persons; they cultivated roughly 415 acres, and possessed 128 cattle, 15 horses, 30 sheep, and 250 hogs. ${ }^{10}$ The demographics of Buxton certainly qualify their farms as extensive, but the Elgin Association financially supported the black refugees. Buxton also enjoyed formal recognition of their settlement from the provincial government of Ontario. Further north into Canada, black refugees from Cincinnati, Ohio, settled the Wilberforce community. Financial mismanagements doomed the Wilberforce community, but even without the financial where-with-all of Buxton, observers found the black farms of Wilberforce were comparable to their white counterparts in Upper Canada. ${ }^{11}$ Without extensive monetary resources, buying livestock was out of the question and tools, when acquired, were worth their weight in gold. Most likely, Liberians depended upon crops as the staple of their agricultural endeavors. With a settlement numbering in the hundreds and as a vital stop on the Underground Railroad it

\footnotetext{
${ }^{10}$ Fred Landon, "Agriculture Among the Negro Refugees in Upper Canada," The Journal of Negro History, Vol. 21, No. 3 (July 1936), p. 306.

${ }^{11}$ Ibid., pp. $308-309$.
} 
is probably safe to surmise that Liberians produced enough to feed themselves and any black refugees moving through their settlement. ${ }^{12}$

The flax and buckwheat common to Mercer County undoubtedly grew on Liberian farms as well. Both crops were relatively easy to grow and had multiple uses. Flax was valued for its fiber, oil, and as a food source. Liberians could use flax to produce thread for homespun textiles, as well as producing twine and rope. Processing the seeds from the flax plant, produced oil and flax seed meal, which Liberians could use as a wood preservative and foodstuff respectively. As beneficial as the flax was to individual households, the plant held commercial potential. As a commodity, the ship building industry depended upon flax fibers to make the sails and ropes aboard ships. Although not particularly useful for sailing on the narrow tributaries of Mercer County, the canal system linked the county to Erie and the Great Lakes, where sailing took on greater importance. As the county grew and the canal provided better access to markets, the possibility existed that Liberians could produce flax for commercial consumption further north. The greatest obstacle to growing and harvesting flax on a larger scale was the requisite labor. Harvesting and processing flax is labor-intensive, but if Liberians had anything in surplus, it was labor. ${ }^{13}$

\footnotetext{
${ }^{12}$ Landon's research places the efforts of black refugee farmers into perspective. Even in communities faced with hostility from white neighbors, black farmers were able to establish themselves as capable if not excellent farmers. Landon, "Agriculture Among the Negro Refugees in Upper Canada," The Journal of Negro History, Vol. 21, No. 3 (July 1936), pp. $304-312$.

${ }^{13}$ Joshua MacFayden, "Following Flax Through History and Rural Space," Unpublished Paper presented at GIS Day at the University of Guelph (4 November 2004). Joshua MacFayden, "Rural Adaptations: The Perine Flax and Lumber Mills in Ontario, 1854 1871," Unpublished Paper presented at the Canadian Historical Association, Annual Meeting (30 May 2005).
} 
The other crop probably grown by Liberians was buckwheat. Like flax, this plant has multiple uses. This easily grown crop would have been useful to Liberians for several reasons. Primarily, buckwheat was a food source. Although not a true cereal grain, once harvested, Liberians could mill buckwheat into flour. The plant's growing time was shorter than most, so buckwheat did not require a lengthy growing season. This was an important consideration for black refugees who may have arrived later in the year. But it was also an importation consideration for Liberian farmers because, they could plant one crop and after its harvest, or failure, they could then plant buckwheat and thereby increase the agricultural output of their land. Again, because Liberians left no known records of their own, it is difficult to ascertain the degree of success they had in farming or even how productive their lands were. What we do know about the land in and around Liberia is that later county residents used the land more for coal mining than they did farming. ${ }^{14}$ So it is possible that the land in Liberia was not the most fertile in Mercer County. Therein lays another benefit of buckwheat farming. Not only did this hardy plant thrive in poor soil conditions, it actually improved soil conditions by making the ground more fertile for other crops. The one shortcoming of buckwheat however, was its relatively low crop yield. So like flax, the buckwheat required more labor than anything else. ${ }^{15}$

\footnotetext{
${ }^{14}$ Liberians sold their lands in 1850 to John Hogue and William Shields, a decade later the land changed hands again and was sold to Jeremiah Bonner and the Mercer Iron and Coal Company. By 1864, the company began mining operations, and before the end of the century was home to the county's largest coal mining operation. History of Mercer County (Chicago: Brown, Runk and Company, Publishers, 1888), 203 - 205, and 467. ${ }^{15}$ Robert L. Myers and Louis J. Meinke, "Buckwheat: A Multi-Purpose, Short Season Alternative," University of Missouri Extension (April 1994).
} 
Whether they farmed flax, buckwheat, or any other combination of crops, the greatest asset in the community was its labor-force. With people-power, Liberians could overcome a lack of machinery and capital, though this probably made for more exhausting work hours for Liberian settlers. The combination of free blacks, resettled refugees, and black refugees still on the move facilitated opportunities for collective farming and living. Richard Travis purchased the original tracts of land that comprised Liberia. These original tracts consisted of 368 acres, which meant that several hundred settlers reduced the ratio of people to land to little more than one acre per person. ${ }^{16}$ Even if Travis never sold any land to his fellow Liberians, he still hosted several hundred people and provided for them directly, either by providing food and shelter, or indirectly by renting or leasing the land. Whatever the case, it is evident that these arrangements dictated extensive farming to support a population of several hundred.

Not all of the people Liberian farms provided for were settlers, some were refugees still on the move, passengers on the Underground Railroad. These passengers were no less a burden on the community than the settlers themselves. Whether Liberians farmed flax, buckwheat, cereal grains, or even raised livestock, considerable labor or capital was required to produce the necessary foodstuffs. Short-term transients, or refugees, who moved through in less than a few days offered little to the work force and even less in capital. However, those who stopped for a week or more, which was not

\footnotetext{
${ }^{16}$ The total of Travis's land purchases came from two transactions with the American Land Company, Mercer County Deed Book E1, 412 - 413 and Mercer County Deed Book P1, 326 - 327, County of Mercer Recorders Office; Mercer, Pennsylvania.
} 
unheard of for black refugees, offered valuable labor to the community. ${ }^{17}$ Liberia could ill afford to provide for long-term transients who did nothing but absorb community resources without putting anything back. Furthermore, these were people with shared experiences, sometimes easily distinguishable by their complexions, but their experiences transcended race. The refugee experience was the basis for the Liberian community. Liberia could not have existed without the cooperative efforts of its residents.

While crops like flax and buckwheat would have sustained the Liberian settlers, the community's continued growth depended largely upon the Underground Railroad. Via internal improvements increasing access to Mercer County, contributed more than economic development. As access increased, so did the flow of black refugees on the Underground Railroad. What sustained the Railroad was not flax or buckwheat, but black refugees and a commitment to antislavery ideology. What Mercer lacked in transportation infrastructures in 1835 , it did not lack in antislavery sentiment. That year residents of Mercer County met to form their own local antislavery group. The sermons of Reverend Nathaniel West, who had occasion to preach at the Presbyterian Church in the borough of Mercer, inspired residents to charter a formal organization. For white residents of Mercer County the issue of slavery initially was "advocated, not as a political but as a reform movement." ${ }^{, 18}$ Local antislavery advocates called for, the entire abolition of slavery in the United States, by collecting and diffusing information concerning its true character, by endeavoring to convince our countrymen, by arguments addressed to their understandings and consciences, that slave-holding is inconsistent with the religion of our Savior, and a heinous crime in the sight of

${ }^{17}$ Van Metre vs. Mitchell ( $3^{\text {rd }}$ Cir. 1853), 314 and Abel Boguess interview by Wilbur Siebert, 9 August 1892, Wilbur H. Siebert Collection, Microfilm Edition (MIC 192, Roll 13) Ohio Historical Society, Columbus.

${ }^{18}$ History of Mercer County (1888), 291. 
God, derogatory to our national character, and that the duty, safety and interests of all concerned require its immediate abandonment. ${ }^{19}$

The heavily religious overtones of the group perhaps indicate West's influence. But, the antislavery activity found within the county did not end with this initial organization. Other groups formed and met regularly. One such group met monthly in the village of Millbrook, outside of the borough of Mercer and just a few miles south of Liberia. ${ }^{20}$

Even with claims of reform and attempts to distance their relationship to politics, local abolitionists could not divorce the two. When they first gathered to charter their organization in 1835 , they met on July 4 , and probably not by coincidence. By 1843 , the tenor of the antislavery discussions in Mercer held no more allusions about the political character of the debate. The Liberty Party began to take root in the county and antislavery agitation took on a new dimension. ${ }^{21}$ In 1848 , the Mercer Luminary reported the formation of the "Friends of Equal Rights," in the county with Samuel White, Charles Cunningham, and George W. White as executive board members. That same year the paper posted notices for anti-slavery lectures and a convention held in Coolspring Township and West Greenville respectively. The close proximity of Coolspring Township to Liberia suggests that perhaps some of the Liberians were able to attend the lectures. ${ }^{22}$ Mercer County carved out its importance in the northwest corner of the state both as an economic up and comer and as a leader in the anti-slavery movement. The

\footnotetext{
${ }^{19}$ Resolution of Mercer County Anti-Slavery Advocates (4 July 1835) reprinted in History of Mercer County (1888), 291.

20 "Account of Wesley Hogue - by His Son," in the Wilbur Siebert Collection. James Lawson to Wilbur Siebert, 22 April 1896, Wilbur H. Siebert Collection, Microfilm Edition (MIC 192, Roll 13) Ohio Historical Society, Columbus.

${ }^{21}$ History of Mercer County (1888), 292.

${ }^{22}$ Mercer Luminary, 10 January 1848, 16 February 1848, and 23 February 1848.
} 
hope of opportunity and the depth of the anti-slavery activism only bolstered the confidence of the Liberians in their choice of a new home.

In 1837, antislavery advocates from across the state met in Harrisburg to form a statewide abolition society. Mercer County figured prominently in the new society and subsequent discussions. Although the largest portion of the state's population lay east of the Appalachian Mountains, western Pennsylvania was less and less a frontier. The mountains presented a physical barrier to regular statewide meetings. It seemed foolhardy to expect delegates from one half of the state to travel to the other on a regular basis for anti-slavery meetings. Even the location of the initial gathering was too difficult for some western delegates to overcome. Crawford County, Mercer's neighbor immediately to the north, was unable to send a delegation. Instead, they forwarded letters, via William Adair of Beaver County, to the organizational meeting. In their letters, Crawford delegates proposed that a statewide organization ought to have offices in the eastern and western portions of the state. Pittsburgh seemed like an obvious choice in the West. It was the largest city west of the mountains and was readily accessible to all parts of western Pennsylvania. These factors were not lost on the Crawford County delegate, Reverend Nathaniel West, who urged that western offices would "mightily strengthen ... brethren in these regions., 23

West agreed that Pittsburgh might make an ideal location in western Pennsylvania, but he also offered another possibility - Mercer, Pennsylvania. For Reverend West, Mercer was an easier trip than Pittsburgh but Mercer County was also prominent enough in antislavery circles as to allow him to suggest holding a meeting

23 "Proceedings of the Pennsylvania Convention, Assembled to Organize A State AntiSlavery Society, at Harrisburg," (Philadelphia: Merrihew and Gunn, 1837), 11. 
there. $^{24}$ The Underground Railroad activity in Mercer might have swayed delegates like Nathaniel West in proposing Mercer as the center of western Pennsylvania's antislavery advocacy. However, antislavery leaders in the East would have had little knowledge of the Underground Railroad activity in Mercer County. More likely formal antislavery organizations would have drawn more notoriety.

All of the development in Mercer County meant significant growth in population. No longer a county of sleepy little hamlets removed from the hustle and bustle of an increasingly industrializing state economy, Mercer emerged as one of the largest and fastest growing counties west of the Allegheny Mountains. As rapidly as the county grew, the black population outpaced the growth of their white neighbors. For all of its growth and success however, the veil of secrecy Liberians depended upon for safety began to slip away. The canal systems that provided greater commercial access to the county also provided slaveholders, in search of lost chattel, better access to black refugees in northwestern Pennsylvania. On at least one occasion, "a slave from the South got among his colored brethren," in Mercer County "and stayed too long. His master followed and took him back." ${ }^{, 25}$ A thriving black settlement in excess of a hundred individuals was increasingly difficult to hide and "slaveholders got to know of this community and would make a break for Sandy Lake" making any passage into or through Liberia an increasingly dangerous prospect. ${ }^{26}$

\footnotetext{
${ }^{24}$ Ibid.

${ }^{25}$ John Hogue to Wilbur Siebert, 1895, Greenville, PA, Wilbur H. Siebert Collection, Microfilm Edition (MIC 192, Roll 13) Ohio Historical Society, Columbus.

${ }^{26}$ Unidentified Letter to Wilbur Siebert, 25 November 1895, Greenville, PA, Wilbur H. Siebert Collection, Microfilm Edition (MIC 192, Roll 13) Ohio Historical Society, Columbus.
} 
Some Mercer County residents observed that slaveholders frequently secured the services of some of their neighbors to use them as "two legged hounds ... to assist and guide the master or officer to the hiding place of the fugitive., ${ }^{, 27}$ Despite the degree of antislavery activity in the county, some folks refused to espouse abolitionist principles and instead supported the enslavement of blacks. Whatever their motivations some private citizens and civil authorities looked to profit from the capture of black refugees in their midst. At least two neighbors near Liberia were willing and perhaps eager to profit from the return of black refugees; both lived alongside the settlement on the western side of the lake. The first Kid Walter was a man, "who was said to be a good friend of the slaveholders and whose business it was to offer his services in helping them find their slaves. ${ }^{28}$ The second person was perhaps more despicable in the eyes of the Liberians. John Mitchell, lived near Liberia almost from its inception, and aided slave hunters in securing their quarry. What made Mitchell so much more despicable was that he was, "an old, drinking, colored coot." ${ }^{29}$ It is unknown if Mitchell himself was a refugee at any point, although his willingness to surrender his neighbors makes such a proposition less likely. Even if he was never a black refugee, his complexion and his support of slave catchers was undoubtedly troubling for Liberians. For all of his efforts, Liberians refused to let Mitchell's treachery go unrewarded,

the next time Mitchell got into the settlement they got after him with gads and whaled (sic) him good. They gave him an awful bastin' ...

\footnotetext{
${ }^{27}$ Joseph White, "Some Reminiscences of Slavery Times," (New Castle, PA, 1891), Wilbur H. Siebert Collection, Microfilm Edition (MIC 192, Roll 13) Ohio Historical Society, Columbus.

${ }^{28}$ James Lawson to Wilbur Siebert, 22 April 1896, Wilbur H. Siebert Collection, Microfilm Edition (MIC 192, Roll 13) Ohio Historical Society, Columbus.

${ }^{29}$ Wesley Hogue to Wilbur Siebert, undated, Wilbur H. Siebert Collection, Microfilm Edition (MIC 192, Roll 13) Ohio Historical Society, Columbus.
} 
and I don't think the colored people about Sandy Lake there ever had anything more to do with Mitchell. ${ }^{30}$

Had Liberians attacked Kid Walter in the same fashion, they risked losing the support or at least the ambivalence of some of their white neighbors. Mitchell on the other hand was a different story; this was a man who at the very least shared the commonality of race, and in nineteenth century America, that was a significant commonality. He may not have been a black refugee at any point in his lifetime but to whites in Mercer County he was a resident of Liberia. Kid Walter's actions, while detestable, were not necessarily unexpected. Liberians were naturally wary of whites they did not know thoroughly. Mitchell, however, was the wolf in sheep's clothing. He did more than betray a few neighbors his actions threatened to shatter the sense of communalism in Liberia.

Although removed by a few counties, one law officer gained a nefarious reputation as a strong proslavery man. Sheriff David Ralston, from Indiana County, assisted slaveholders in capturing Anthony Hollingsworth and Charles Brown in 1845. So strong were his feelings about slavery that even in the midst of the Civil War he attempted to lecture on the divine recognition of slavery at the county courthouse in Indiana. ${ }^{31}$ He was in every sense the very "two-legged hound" Liberians feared most. He was not unknown to the citizens of Mercer County, his reputation preceded him. Despite being the Sheriff of Indiana County, Ralston did not confine his efforts to that county. He was willing to travel, and often did, into neighboring counties to hunt down black refugees. In 1847, Ralston raided the home of Samuel Marshall in neighboring

\footnotetext{
30 Ibid.

${ }^{31}$ Clarence D. Stephenson, Indiana County $175^{\text {th }}$ Anniversary History, Vol. IV, (Indiana, PA: A.G. Halldin Publishing, 1983), 329 and 341.
} 
Butler County in search of black refugees. When he did not readily find his quarry, Ralston attempted to gain information on their whereabouts by threatening Mrs. Marshall at gunpoint. ${ }^{32}$ White abolitionists knew enough of Ralston that they recognized him on sight, without introduction. On at least one occasion a correspondent for the Mercer Luminary reported seeing Ralston in attendance at an antislavery lecture. ${ }^{33}$ Therefore, it stands to reason that if white abolitionists knew Ralston, Liberian settlers were undoubtedly aware of the sheriff and his proslavery intentions.

Sheriff Ralston was not a novice as a slave catcher, his service as a law officer probably prepared him well for the business. By 1853 , he gained national recognition for his role in the Van Metre v. Mitchell case. A slaveholder, Garret Van Metre, secured Ralston's service in securing his lost chattel. Unfortunately, for Van Metre and Ralston, a local abolitionist, Dr. Robert Mitchell of Indiana County, thwarted their efforts. Dr. Mitchell provided food to a group of blacks enslaved by Van Metre but perhaps most offensive to the slaveholder, Dr. Mitchell helped the black refugees evade capture. Incensed, Van Metre pressed charges against Mitchell under the provisions of the Fugitive Slave Act of 1850. Ralston was a central figure in the case and his actions galvanized the abolitionist activity in Indiana County and northwestern Pennsylvania.

In 1853, Dr. Robert Mitchell faced federal charges for harboring and concealing fugitive slaves in his home. For four months, he allowed black refugees to live and work on his farm, and supplied them with guns and ammunition as well as knives, not a bad idea considering the close proximity of Sheriff Ralston. Van Metre and two companions

${ }^{32}$ Butler County is immediately adjacent to both Indiana and Mercer Counties, bordering Mercer to the north and Indiana to the southeast. "An Infamous Outrage," Mercer Luminary from the Butler Whig, 20 October 1847.

33 "Correspondence of the Luminary," Mercer Luminary, 16 February 1848. 
tracked his chattel to Indiana, Pennsylvania and quickly followed them there. By coincidence, Van Metre and his companions looked for lodging at the Indiana House, a hotel owned and operated, by Sheriff Ralston. At that point, Van Metre needed nothing more from Ralston than lodging and a place to restrain his lost chattel, the sheriff obliged these simple needs and obviously turned a profit. Unfortunately, for Van Metre, Dr. Mitchell challenged his claims of ownership in the local courts. Some careful legal maneuvering kept the black refugees free from enslavement, but Van Metre was unwilling to give up so easily.

Clearly, Van Metre had length discussions with Sheriff Ralston about the situation because in a few months the slaveholder again attempted to secure his property. This time he made no efforts personally to capture the black refugees, instead he hired Ralston. By this point, Mitchell knew that Garret Van Metre laid claim to the black refugees as his chattel and yet he refused to turn them over to authorities, instead, he continued to shield them from Van Metre. Apparently aware that Mitchell provided the refugees with weapons to defend themselves, Ralston and a posse of eleven men set about capturing them in the dead of night. Ralston's quarry was three black refugees, so in gathering a posse of eleven he left little to chance. Although accounts make no mention of the guns, they do mention that Ralston and his party brought along a battering ram. ${ }^{34}$ It is hard to believe, knowing that the refugees were armed to the teeth, that Ralston and his men were not equally armed. Despite the posse's preparedness, the black

\footnotetext{
${ }^{34}$ Van Metre vs. Mitchell ( $3{ }^{\text {rd }}$ Cir. 1853) 312 - 314; "How Man-Hunters Were Foiled by the Work of an Indiana County Judge," Pittsburgh Dispatch, 13 February 1898. "Biography of Dr. Robert and Jane C. Mitchell," compiled by Robert T. Mitchell, Wilbur H. Siebert Collection, Microfilm Edition (MIC 192, Roll 13) Ohio Historical Society, Columbus.
} 
refugees were unwilling to submit quietly. They resisted to the best of their abilities and denied Ralston the satisfaction of complete success. Two of the three refugees escaped again, and leaving nothing to chance left immediately for Canada. Ralston and his posse captured the third however returned him to bondage in Virginia. The loss of the other two, left Garret Van Metre embittered and he subsequently sued Robert Mitchell in federal court and won. The federal courts ordered Mitchell to pay the princely sum of $\$ 10,000$. In order to raise the necessary money, Mitchell's farm went up for auction at the next sheriff's sale under the "hammer" of David Ralston. ${ }^{35}$

David Ralston, although not unknown to residents of Mercer County, was not a native. He would have relied on men like Kid Walter and John Mitchell for information on the whereabouts of black refugees in and around Mercer. These connections only circulated his reputation that much more. Others who shared Ralston's sympathies towards slaveholders lived closer than many Liberians would have liked. Despite the abundance of anti-slavery activity in Mercer County, there were an equal number of residents and perhaps more who were pro-slavery. S.P. Wright remembered that in his part of the county, "the place was full of pro-slavery Democrats." ${ }^{36}$ Reflecting on the antebellum period in Mercer County, historians in 1888 were inclined to believe that,

Mercer County was not agitated as much over the enormities of the African slave system in the South as other portions of the state lying contiguous to that region. ${ }^{37}$

35 Ibid.

${ }^{36}$ S.P. Wright to Wilbur Siebert, 18 January 1896, Wilbur H. Siebert Collection, Microfilm Edition (MIC 192, Roll 13) Ohio Historical Society, Columbus.

${ }^{37}$ History of Mercer County (1888), 290. 
However, the efforts of Wilbur Siebert and his research on the Underground Railroad in western Pennsylvania indicate otherwise. But that simple statement does confirm that there was a diversity of opinions on the slavery debate in Mercer County.

The presence of both viewpoints frequently left the county divided. In some cases the depth of the conflict split communities and churches alike. In one Presbyterian congregation, the pastor was proslavery, but the majority of his congregation was not. Failing to rectify the disagreement, "the preacher and one church elder went one way; the other five elders and the best part of the congregation went the other way." ${ }^{38}$ The tension pitted neighbors against one another at times; one pro-slavery Mercerite declared, "He would report any man that helped a slave on his road to freedom.. ${ }^{39}$ In the western part of the county John Young, became so disgusted with his pastor's proslavery leanings in New Wilmington that he left his congregation and formed his own church on his property near Indian Run. This was the same John Young, who was one of the charter members of the Mercer Abolition group in 1835, and actively assisted on the Underground Railroad through Indian Run. ${ }^{40}$

Young's antislavery views, however, had their limits. In 1851, a drover named Charles May, sold Frank Jackson, a free black from New Castle, into slavery. Jackson had grown up with Young's family and went with May to Richmond, Virginia, both under the employ of Young. Once there, Jackson "was kidnapped and taken south, being

\footnotetext{
38 Ibid.

39 Ibid.

${ }^{40}$ Lillian Reeher, "Anti-Slavery at Indian Run Began at Neshannock Church,” Wolf Creek Legacy II, 67, Mercer County Historical Society; Mercer, Pennsylvania.
} 
sold to a planter in the northern part of North Carolina. ${ }^{, 41}$ Charles May apparently saw the opportunity to profit doubly from his trip to Richmond because he sold Jackson into slavery. Jackson managed to escape from his captors briefly; they recaptured him a few days later. ${ }^{42}$ Failing to return from his errand, Jackson's friends went looking for him. When they discovered what had transpired, they appealed to state authorities to intervene on Jackson's behalf. Correspondence between the governor of Pennsylvania and the governor of North Carolina yielded an agreement to release Jackson into the custody of friends from New Castle. Local abolitionists raised money to defray the travel expenses Jackson incurred on his trip home. Shortly after his return Young scoffed to a neighbor that, "It might have been better for that nigger if he had been left where he was. He seems to be just suited for a plantation life among a lot of other niggers. ${ }^{.43}$

John Young was certainly not alone in his thinking. Even if others in Mercer never said it aloud, Young's comments reflect the conservative nature of local abolitionism and indeed state abolitionism. While Pennsylvania initially took the lead in the abolition of slavery, by the time black refugees settled into Mercer County, the state lagged behind Massachusetts as the hotbed of abolitionist activity. Pennsylvanian abolitionists had long practiced a gradual approach to emancipation. The state's shared borders with Virginia, Maryland, and Delaware perhaps dictated such an approach. Massachusetts however, suffered less from the delicacies of sharing borders with slave states, and the Garrisonian approach reflected that more emotional response to abolition.

\footnotetext{
41 "The Kidnapping and Recovery of Frank Jackson; Two Underground Stations in New Castle, Lawrence County," New Castle Daily News, 5 March 1897.

42 "Fruits of the Fugitive Law," The National Era, 26 June 1851.

43 "The Kidnapping and Recovery of Frank Jackson; Two Underground Railroad Stations in New Castle, Lawrence County," New Castle Daily News, 5 March 1897.
} 
Historian Richard Newman compared the two states and the abolitionist activity within them. He concluded that Pennsylvanians were rather "dispassionate" in confronting slavery, preferring a rational approach more dependent upon "learned legal briefs," than impassioned speeches. ${ }^{44}$

Politically, the Liberty Party carried on the gradual emancipation agenda and more than a few northwestern Pennsylvanians joined the ranks of the new party. At the party's national convention in 1851, three representatives hailed from the northwest corner of the state: H.P. Clough, James Catlin, and John King. None of the men represented Mercer County, though Catlin once lived and worked there at the water cure facility. ${ }^{45}$ In Mercer County, support for the party went back to 1843 , when a central organizing committee formed to build support for the new party within the county. The central committee was a who's who list of abolitionists in and around Mercer; Robert Stewart, William Scott, Robert Hanna, Joseph McDonald, Joseph Sykes, Joseph McQuillan, James Kilgore, and Frank Jackson's employer - John Young. ${ }^{46}$

The recovery of Frank Jackson aptly demonstrates the diversity of opinions, in northwestern Pennsylvania, but also underscores the strength of the anti-slavery community. Jackson's friends had access to Pennsylvania's governor a resource that expedited his release. So even if antislavery advocates were few in number in that portion of the state, they lacked nothing in terms of resources. Even John Young's response was indicative of diversity within the anti-slavery movement. Despite his anti-

\footnotetext{
${ }^{44}$ Richard S. Newman, The Transformation of American Abolitionism: Fighting Slavery in the Early Republic, (Chapel Hill: University of North Carolina Press, 2002), 2 and 6. ${ }^{45}$ Frederick Douglass' Paper, 25 September 1851.

${ }^{46}$ Rachel Darby, ed., "Follow the Drinking Gourd: Walking Tour of Mercer's Historic Underground Railroad and Abolitionist Era Sites," Mercer County Historical Booklets (Mercer, PA: Mercer County Historical Society, 2002), 23.
} 
slavery thoughts, clearly John Young believed some were more deserving of bondage than others. It might not be a stretch to assume that Young was not a Garrisonian abolitionist. Earlier in 1841, the Mercer Luminary responded to another case within the county urging readers that, "Whatever the laws require with respect to runaway slaves, however severe, should be obeyed by our officers. ${ }^{47}$ Mercer County was certainly no antislavery monolith, but it was not inconsequential either. The growth in northwestern Pennsylvania did nothing to assuage the diversity of opinions in regards to slavery. On the contrary, as more and more people moved into the region, the greater the diversity and at times the greater the conflict. Antislavery advocates were no more successful keeping slaveholders and their agents out of the county, any more than proslavery advocates could keep out black refugees.

Liberians faced the uncertainty of new neighbors' sometimes-conflicted views on slavery. This difference in opinion meant Liberians had to be increasingly mindful of their contact with neighbors. Men like David Ralston, Kid Walter, and John Mitchell were every bit the threat to their community that slaveholders themselves were. Other threats to the freedom and the continued good fortune of black refugees in Liberia arose outside of the county as quickly as within. Some of the other threats were more indirect in their approach and had less to do with the support of slavery and more to do with irrational fears. The increasing black population troubled many whites in Pennsylvania. Opposition to slavery was one thing, but overcoming deeply engrained racial stereotypes proved even more difficult. Whites in the eastern portion of the state called for a repeal of voting rights for black men. The inspiration for the repeal stemmed both from the

47 “Slave Case," Mercer Luminary, 6 October 1841. 
increasing black population in Pennsylvania and the backlash from slave insurrections. Hysterical whites believed free blacks were the source of insurrections, and in Pennsylvania, some believed the climate was conducive to organizing large-scale insurrections. Repealing black voting rights ensured limited political resistance from systematic and institutional racism. But, the action also reaffirmed a sense of security for many whites who feared black refugees would overrun or worse, overthrow the state.

The one insurrection that had the greatest impact on Pennsylvania, and ultimately Liberia, between the 1830s and 1840s was Nat Turner's revolt in Virginia. In 1831, Nat Turner and his associates attempted to overthrow slavery; although Turner's revolt was unsuccessful, his efforts generated considerable fear both in and out of Virginia. The fear generated by Turner and his compatriots was more complex and further reaching than the concern that they might actually succeed in ending chattel slavery in Virginia, let alone America. The depth of the fears exposed the irrationality of nineteenth century racism and the paternalistic nature of American slavery. In terms of enslaved participation, Turner's Revolt was not the largest or even most widespread in American history, that honor belongs to Deslondes' Revolt in Louisiana. ${ }^{48}$ What set Turner's revolt apart was the killing of whites; Turner's soldiers created more white casualties during their reign of terror than any other slave insurrection in the states. That fact alone shook whites to their core.

The killing of more than fifty whites, however, raised even broader concerns for Virginia's slaveholders. Why would enslaved blacks kill whites in a seemingly

\footnotetext{
48 Thomas Marshall Thompson, "National Newspaper and Legislative Reactions to Louisiana's Deslondes Slave Revolt of 1811," Louisiana History: The Journal of the Louisiana Historical Association, Vol. 33, No. 1 (Winter 1992), 5.
} 
indiscriminate fashion? Why did they kill so many whites? Moreover, what set them off in the first place? A general sense of "how could this have happened?" overtook Virginia. If but a few slaves from one plantation planned and executed such an insurrection, explanation and blame were more readily available. Virginians could look to the respective slaveholder of a plantation for explanation and perhaps blame. Turner and his associates however, did not come from one central plantation; multiple slaveholders claimed them as chattel. This undoubtedly troubled many Virginians because it denied them a simple explanation and ultimately a simple remedy to averting future crises. The belief that the inherent inferiorities of blacks and well-regulated control over enslaved chattel inhibited such large-scale killings betrayed Virginia's slaveholders. Turner's revolt was not the first in Virginia's history. Earlier revolts prompted slaveholders to evaluate insurrections and their causation and then respond by fortifying control in areas found lacking. The 1831 insurrection forced slaveholders to face several frightening possibilities: one, the existing slave codes and their enforcement were insufficient; two, free persons were subverting the authority of slaveholders and undermining their right to property; or three, no amount of legislation could ever curb the potential for slave insurrection. ${ }^{49}$

\footnotetext{
${ }^{49}$ Although not the largest slave insurrection, Turner's Revolt had a lasting impact on both abolitionists an pro-slavery advocates. Turner's impact on southern slaveholders is perhaps illustrated in two works, The Confessions of Nat Turner and "The Abolition of Negro Slavery." The former, is the deposition taken by attorney Thomas Gray in the days following Nat Turner's capture, and it speaks volumes about slavery and slave resistance. The latter work by Thomas Dew, articulates both the slaveholders' resistance to abolition but also the fear and concerns of white southerners following the revolt. The combination of these two works provide the foundation for the voluminous historiography of Nat Turner's Revolt.
} 
In the immediate aftermath of Turner's Revolt, both state and local authorities took measures to ensure Turner's work did not add more white casualties and revolt across the commonwealth. Local vigilantes, in Southampton County where the insurrection began, also set about crushing the possibility of future insurrections. In one case,

A party of horsemen started from Richmond with the intention of killing every colored person they saw in Southampton County. They stopped opposite the cabin of a free colored man who was hoeing in his little field. They called out, 'Is this Southampton County?' He replied, 'Yes Sir, you have just crossed the line, by yonder tree.' They shot him dead and rode on. ${ }^{50}$

The knee-jerk reaction to Turner's Revolt however, was counterproductive, it brought local communities and their economies to a standstill as whites were too afraid to conduct business as usual. While some hunted blacks they were sure were part of Turner's Revolt, others like the horsemen from Richmond looked to kill all blacks in response to the crisis. Simply killing the entire black population in Virginia, may have satisfied the need for cathartic vengeance, but that would have defeated the purpose of controlling the slave population in the first place. That meant state and local authorities would have to commit considerably greater resources to curb any further insurrections.

Paternalism had long given slaveholders a false sense of security. They believed as patriarchs, that they acted in the best interests of their families and chattel, and that family and chattel were wholly dependent upon them. The illusion, that they took preventative measures, in squashing violent discontent in the enslaved community by acting in paternal fashion, was just that - an illusion. Paternalism offered little protection

${ }^{50}$ Thomas Wentworth Higginson, Travellers and Outlaws as quoted in John W. Cromwell, "The Aftermath of Nat Turner's Insurrection," The Journal of Negro History, Vol. 5, No. 2 (April 1920), 212. 
from Nat Turner and his followers; it had only betrayed slaveholders by leading them to believe that Turner's inferiority would prevent him from killing sixty whites. Likewise, the civil attempts to codify control of enslaved chattel had proved insufficient at that point. Increased codification and enforcement were not by themselves the answer. Without addressing the root causes of the insurrections, slaveholders toiled in vain to prevent future violent revolts.

If no amount of legislation alone could curb insurrection, that left Virginia slaveholders with two remaining possibilities: either they must consider abolishing slavery entirely or that they must abolish the outside influences, which inspired Turner and his forces. Considering the importance of slavery to the commonwealth's economy the former was not a popular option, and although legislators considered abolition, they never passed legislation enacting it. Proslavery voices like Governor Floyd truly believed that Turner's Revolt was just a small part of a farther-reaching conspiracy. According to Floyd, outsiders fomented the insurrection,

unrestrained fanatics in some of the neighboring States, who found facilities in distributing their views and plans amongst our population either through the post office or by agents sent for that purpose throughout our territory. ${ }^{51}$

Considering the resolves of organizations like Mercer County's first abolition group, Floyd had good reason for concern. The Pennsylvania group believed that,

The diffusion of anti-slavery sentiments through the Northern States is not only necessary to convince our Southern brethren of the enormity of the traffic in human souls, but also the whole moral energies of the nation be brought to bear on the monster, slavery, which sits like an incubus in our land. ${ }^{52}$

${ }^{51}$ John Floyd as quoted in, "The Aftermath of Nat Turner's Insurrection," 218.

${ }^{52}$ Resolution of Mercer County Anti-Slavery Advocates (4 July 1835) reprinted in History of Mercer County (1888), 291. 
Believing that fanatics in neighboring states bore responsibility for the revolt, Floyd endeavored to preserve "the good understanding which existed and ought to be cherished between the different numbers of this union." 53 The governor embarked on a letter writing campaign with governors of neighboring states. Clearly, Floyd hoped that the intervention of neighboring states could prevent further corruption of the paternal slave system in Virginia.

Governor Floyd's correspondence met with a met with some success. Within short order, Ohio's governor addressed his state's legislature and spoke about the necessity of prohibiting further black immigration into the state. At the same time Maryland's state legislature enacted legislation prohibiting the immigration of free blacks within in its borders. Likewise, Tennessee's legislature also passed legislation prohibiting free blacks from entering the state. ${ }^{54}$ It must have provided some comfort to Governor Floyd when he received word that his neighbors considered his pleas. Within his home state, the legislature also moved to address its growing free black population and their subsequent impact upon enslaved blacks. Virginian authorities explored their options in deporting free blacks. Although, the commonwealth officially demanded the removal of free blacks from the state as early as 1806 , enforcement was lax and the code of relatively little consequence. ${ }^{55}$ In the aftermath of Turner's Revolt the legislature revisited the possibility of deporting free blacks. Less than a year after the revolt,

\footnotetext{
53 Ibid.

${ }^{54}$ Cromwell, "The Aftermath of Nat Turner's Insurrection," $231-232$.

${ }^{55}$ An Act to Amend the Several Laws Concerning Slaves. The Statutes at Large of Virginia, From October Session to December Session 1806, 3; 251 - 253 (1806).
} 
legislators reviewed a bill proposing the removal of free blacks from the commonwealth. ${ }^{56}$

None of Virginia's neighbors was immune to the hysteria created by Turner's Revolt. The general fear stemming from the bloodshed, coupled with Governor Floyd's correspondence resonated well beyond Southampton County, Virginia. Not only had Ohio, Maryland, and Tennessee responded to the turmoil, Delaware and North Carolina responded to fears that free blacks threatened the relative peace of their sovereignty. ${ }^{57}$ Even in Pennsylvania, the tenor of race relations changed markedly after Turner's Revolt. Just like their counterparts other states, Pennsylvanian officials looked into the possibility of prohibiting the immigration of free blacks into the state. Late in 1831 Franklin Vansant, a state legislator from Philadelphia introduced a bill to the General Assembly, "to prohibit the emigration of negroes and mulattoes in this commonwealth." 58 Pennsylvania officials were concerned about the threat of black violence within the state, but they were also concerned with Virginia's proposal to deport its free black population. After all, if Virginia perceived them to be a threat and therefore undesirable, why would Pennsylvania want them? Were they not just as dangerous in the states surrounding Virginia as they were within?

Even unsaid, the inference made by Virginia's Governor was clear to his neighbors; free blacks and abolitionists were dangerous - beware. Free blacks and abolitionists aroused aspirations of freedom in enslaved blacks. That arousal threatened the very heart of chattel slavery in America. Discontented slaves meant constant

\footnotetext{
${ }^{56}$ Cromwell, "The Aftermath of Nat Turner's Insurrection,” 229.

57 John Floyd as quoted in, "The Aftermath of Nat Turner's Insurrection," 218.

${ }^{58}$ Julie Winch, Philadelphia's Black Elite: Activism, Accommodation, and the Struggle for Autonomy, 1787 - 1848 (Philadelphia: Temple University Press, 1988), 132 - 133.
} 
disruptions and the dedication of more resources to preserve their enslavement. With such an ever-increasing financial commitment, slavery ceased its viability. Furthermore, slave states lacked the ability to control abolitionist activity outside of their own borders; they depended upon pro-slavery sympathies within free states. Slave states needed their neighboring free states to view abolitionist ideology as threatening, and more importantly to view free blacks as threatening. Placing free blacks at the center of Turner's violent insurrection certainly portrayed them in a negative light. But it also painted them as ungrateful citizens of Virginia. Although Governor Floyd believed free blacks had a hand in the insurrection, he referred to them as "that class of the community, which our laws have hitherto treated with indulgent kindness." ${ }^{\text {59 }}$ This apparent wishful thinking negated the fact that slaveholders had tried for decades to rid themselves of free blacks in the commonwealth.

Virginia in essence attempted to not only export free blacks from the commonwealth, but also sought to export the corresponding fear of free blacks. Northern Free states, like Pennsylvania, had their own reasons to be concerned with an increasing black population. The fact that slaveholders branded free blacks as at least ungrateful and at most violently anti-white, certainly contributed to fears in northern states. Many northern whites still viewed blacks, irrespective of their freedom, as a lower class. When John Young suggested that Frank Jackson was better "suited for a plantation life among a lot of other niggers," he was not reflecting kindly upon his hired help. ${ }^{60}$ Even by popular accounts around New Castle and Mercer County, Frank Jackson "was not by any means a

\footnotetext{
${ }^{59}$ John Floyd as quoted in, "The Aftermath of Nat Turner's Insurrection," 219.

60 "The Kidnapping and Recovery of Frank Jackson; Two Underground Railroad Stations in New Castle, Lawrence County," New Castle Daily News, 5 March 1897.
} 
brilliant specimen of his race. ${ }^{, 61}$ Fears that a rapidly growing black population would overwhelm the white community, yielded to concerns that men like Jackson had access to the ballot and could affect the state socially, politically, and economically with their judgment likely scared neighbors like John Young. For the most part however, those fears remained confined to the urban centers inside Pennsylvania. The urban centers of Pennsylvania had the largest concentrations of blacks in the state. It was not coincidence, then, that a state legislator from Philadelphia introduced a bill to prohibit further black immigration into the state. Although Mercer's black population grew rapidly, that growth was relative to the area. Whites still dominated the census rolls. Consequently, there does not appear to have been any mass hysteria over the increasing black population in the county.

In Pennsylvania, Philadelphia became the center of anti-black immigration sentiment. A year after Turner's Revolt, a Quaker abolitionist attempted to relocate almost one hundred black refugees to Pennsylvania. Whites twice turned away the refugees, once at the waterfront in Philadelphia and a second time down river in Chester, Pennsylvania. ${ }^{62}$ For Philadelphia economic downturns also contributed to the resistance to black immigration. Working class whites felt pressured by the increasing black population in the city and saw them as competitors for jobs. Legislators like Franklin Vansant sought to capitalize on the atmosphere and manipulated those feelings for political gains. Vansant believed that if unchecked, more than 100,000 black refugees would cross the Mason-Dixon Line seeking refuge inside of Pennsylvania. He also knew

\footnotetext{
${ }^{61}$ Ibid.

${ }^{62}$ Gary Nash, Forging Freedom: The Formation of Philadelphia's Black Community, 1720 - 1840, (Harvard University Press: Cambridge, MA, 1988), 2.
} 
that such figures, whether he believed them or not, generated anxiety within working class whites. Vansant hoped that anxiety would turn to votes and consequently political power for himself. ${ }^{63}$

The bill was read a second time before the legislature. Prior to the second reading Vansant and his supporters altered their proposal. The revised bill asked legislators to consider requiring annual censuses to enumerate blacks on a county level. The proposed censuses provided names, physical descriptions, and ages of all black residents, so that authorities could track the movement of blacks within the state. Support for Vansant's bill came from the southern portions of the state, from counties along the Mason-Dixon Line that felt the greatest quantitative impact of black refugees. ${ }^{64}$ Although the bill garnered considerable support from southern counties, Vansant and his political allies failed to get the measure passed. Racial tensions continued to fester, so much so that between 1834 and 1849, no less than five race riots occurred in Philadelphia. ${ }^{65}$ The riots in Philadelphia had little effect on the lives of the Liberian settlers in Mercer. What did affect them was the underlying animosity towards blacks, because it began to spread along the state's southern boundary.

All of the racial tension in Philadelphia provided grist for the political mill, the 1836 elections in Pennsylvania. When Governor Ritner and the Whig Party called for voter registration prior to the elections, Democrats cried foul. They believed that the

\footnotetext{
${ }^{63}$ Winch, Philadelphia's Black Elite, 132 - 133; Smith, "The End of Black Voting Rights," 287.

${ }^{64}$ Smith, "The End of Black Voting Rights," 282; Journal of the Senate of the Commonwealth of Pennsylvania, Vol. 1 (Harrisburg: Henry Welsh, 1831 - 1832), 287.

${ }^{65}$ Emma Jones Lapansky, "'Since They Got Those Separate Churches': Afro-Americans in Jacksonian Philadelphia," American Quarterly, Vol. 32, No. 1 (Spring, 1980), 75.
} 
voter registration drive unfairly targeted working class whites. ${ }^{66}$ Democrats became the champions of white working class voters and built upon the earlier economic anxieties. White voters rewarded the Democratic Party by voting them into power in the state legislature. Once in office, the Democrats tried to correct the excesses the perceived of their Whig - Anti-Masonic predecessors. They promptly nullified the contract for the Ohio River-Lake Erie Canal. ${ }^{67}$ All of these political developments in Harrisburg had a mixed effect in Mercer County. While the nullification of state contracts threatened to derail the canal project in Mercer County, the assistance of private investors ensured its completion. None-the-less, the Democrat's efforts were probably not met with enthusiasm in Mercer County. For blacks in Mercer, the impact of the political turnover in Harrisburg was not the potential disruption of any construction project. In fact, the political turmoil only masked the real problem for Liberians. The real problem was the increasing hostility towards black refugees. Democrats had used those sentiments to gain control of the legislature, and now threatened to use those sentiments to secure their political power.

The political developments in Philadelphia and Harrisburg were not the only events to affect black refugees in Mercer County. In 1837, the capture and return of a black refugee to bondage held long-term implications for Liberia. Agents for Margaret Ashmore entered Pennsylvania, and captured Margaret Morgan, previously enslaved by the Ashmore family, and returned her to bondage. Morgan's capture drew Pennsylvania and Maryland into direct confrontation in the debate over personal liberties and property

\footnotetext{
${ }^{66}$ Smith, "The End of Black Voting Rights," 284.

${ }^{67}$ History of Mercer County Pennsylvania (1877), 21.
} 
rights. ${ }^{68}$ Until the passage of the Fugitive Slave Law of 1850, this case was the litmus test for interstate "fugitive slave" cases. By 1842, the case had traveled from the municipal level all the way to the Supreme Court of the United States. Edward Prigg and Nathan Bemis entered Pennsylvania with two other men, Jacob Forward and Stephen Lewes in search of Margaret Morgan. The four men quickly located Margaret and applied for a warrant to take her back into Maryland as enslaved chattel. ${ }^{69}$ A legal technicality thwarted their efforts to return Morgan to Maryland, and rather than wait for the legal system to correct the error the four men took matters into their own hands:

Behold the dreadful villainy of a slaveholder: at midnight, when the neighborhood were locked in sleep, he and his gang arose and took the woman and children, and before daylight, he had driven with such speed, that they were secured in one of the great prison houses, to-wit, the State of Maryland. ${ }^{70}$

Once they crossed the Mason - Dixon line the four men set events into motion that placed the case on a national stage. According to Pennsylvania law, the four men had seduced and carried away a woman from the Commonwealth "with a design and intention then and there of selling and disposing of, or causing to be sold ... as and for a Slave or Servant for life. To the evil example of all others in like cases offending, [this was] contrary to the form and Statute in such cases ... against ... the Peace and dignity of the Commonwealth., ${ }^{, 71}$

Despite repeated requests, Maryland's governor refused to extradite the four men to face kidnapping charges. Negotiations between the two states yielded a compromise;

${ }^{68}$ Prigg v. Pennsylvania, 41 US (16 Peters) 539 (1842).

${ }^{69}$ Prigg v. Pennsylvania, 41 US (16 Peters) 556 (1842).

70 "The Act of 1793" (1843), in Luther Rawson Marsh, ed., The Writings and Speeches of Alvan Stewart, (New York: A. B. Burdick, 1860), 381.

${ }^{71}$ York, PA. 1837. "Grand Inquest of the Commonwealth of Pennsylvania" Court of Oyer and Terminer - Middle District (Pennsylvania State Archives). 
both states agreed that if Pennsylvania's courts rendered a special verdict, Maryland authorities would extradite Prigg to face charge of kidnapping. ${ }^{72}$ If the prosecution succeeded in gaining a conviction Pennsylvania agreed to have the case referred to the Supreme Court of the United States. ${ }^{73}$ In January of 1840, a jury of twelve convicted Edward Prigg of kidnapping Margaret Morgan and counsel for Prigg subsequently appealed the case through the state courts and onto the United States Supreme Court. ${ }^{74}$ Within two years, the Prigg case left the local courts and argued before the United States Supreme Court, where justices rendered a verdict. The Court found in favor of the plaintiff and upheld slaveholders' right to property. The decision of the court was a harsh blow to opponents of slavery; in upholding the right to property, the Supreme Court recognized the nationalization of slavery. ${ }^{75}$ The decision eradicated the informal boundary between slavery and freedom, and gave slaveholders the right to recover their chattel in any state or territory in the union regardless, of the local status of slavery.

Nationalization also aroused further suspicions surrounding blacks in Free states. It allowed whites to presume that blacks were refugees from bondage until they could prove otherwise. In that sense, the decision stripped blacks of equal protection under the law. Despite these concerns, Liberians did not leave Mercer any sooner then they had previously. Furthermore, most whites in Mercer already presumed blacks around Liberia were refugees, and with good reason. Liberians lived along side men like Kid Walter and John Mitchell long before the court's ruling, and the threat of Sheriff David Ralston

\footnotetext{
72 York, PA. 1840. "April Sessions 1837 - The Commonwealth v. Edward Prigg, Nathan Bemis, Jacob Forward, Stephen Lewes” (York County Archives), 221.

${ }^{73}$ Prigg v. Pennsylvania, 41 US (16 Peters) 557 (1842).

${ }^{74}$ York, PA. 1840. "April Sessions 1837 - The Commonwealth v. Edward Prigg, Nathan Bemis, Jacob Forward, Stephen Lewes" (York County Archives), 221.

${ }^{75}$ Prigg v. Pennsylvania, 41 US (16 Peters) (1842).
} 
raiding their village actually subsided after the ruling. The court's ruling in the Prigg case did not produce any new threats to Liberian freedom. It simply reaffirmed what Liberians already knew.

The court's ruling in the Prigg case was proslavery, but only in a superficial sense. ${ }^{76}$ On the surface, the court's decision essentially nationalized slavery. Prigg solidified slaveholders' right to property even across state lines. However, the interstate nature of the dispute fell under federal jurisdiction, not any one state. Jurisdiction and enforcement were central to the impact of the decision on free blacks and black refugees across the country. Counsel for Prigg argued before the Supreme Court that:

If the power of enforcing its execution were left to the states, it could not but have been foreseen that its whole purpose might be defeated. That other states might legislate or not. In the one case leaving the owner without legal means to vindicate his rights; in the other, embarrassing the prosecution of them, so as to delay or defeat them. ${ }^{77}$

The court agreed with counsel, but went a step further in its ruling; it allowed states to refuse to enforce the federal law. In fact, the court's ruling prohibited state and local authorities from assisting in the recovery process. ${ }^{78}$ Because jurisdiction was central to the case, the Supreme Court believed only federal authorities were compelled to enforce federal law. The decision opened the door to a new round of personal libery laws

\footnotetext{
${ }^{76}$ The impact of Prigg on the slavery debate is well covered by Paul Finkelman in two essays, "Prigg v. Pennsylvania: Understanding Justice Story's Nationalism," The Journal of Supreme Court History, Vol. 2 (1997), 51 - 64 and "Prigg v. Pennsylvania and Northern Courts: Anti-Slavery Use of a Pro-Slavery Decision," Civil War History (March 1979), 5-35. A decade earlier in 1969, Joseph Burke also weighed in on the discussion with "What Did the Prigg Decision Really Decide?" Pennsylvania Magazine of History and Biography, Vol. XCII (1969), 73 - 85.

${ }^{77}$ Prigg v. Pennsylvania, 41 US (Peters) 505 (1842).

${ }^{78}$ Life and Letters of Joseph Story, Associate Justice of the Supreme Court of the United States, and Dane Professor of Law at Harvard University, Vol. II (Boston: Charles C. Little and James Brown, 1851), 392.
} 
designed to thwart the institution of slavery. By 1847 , Pennsylvania responded to the Supreme Court's decision and prohibited state and local authorities from assisting in the recapture of enslaved blacks. ${ }^{79}$

The new round of personal liberty laws spawned by the Prigg decision consistently annoyed and thwarted slaveholders in their attempts to recover escaped chattel. Dependence upon federal authorities limited slaveholders in their abilities to capture black refugees. Men like David Ralston and Kid Walter profited from the needs of southern slaveholders, but also provided valuable services both with their knowledge and with physical assistance. When Pennsylvania outlawed local assistance in the recovery of black refugees, slaveholders lost a valuable resource. It assured Liberians that David Ralston was not going to raid their village in the near future. Frustrated slaveholders pushed for stronger federal legislation to assist in the recovery of escaped chattel, and in 1850 got their wishes granted. The Fugitive Slave Act of 1850 closed the loophole created by Prigg, which prohibited local authorities from assisting in recovery.

The Fugitive Slave Act of 1850 was the most serious threat to Liberian freedom. It was the one threat that proved insurmountable. Within a year after its passage, Liberia and its settlers were gone. Except for a few individuals, the Liberians left together for Canada. In leaving their farms and their homes, they became refugees in flight once again. William Edwards was emblematic of the residents of Liberia, for at least two years he felt the joy of freedom, but the passage of the Fugitive Slave Act of 1850

\footnotetext{
${ }^{79}$ Niles National Register, Vol. 72, March 1847 to September 1847 in the Wilbur Siebert Collection, Wilbur H. Siebert Collection, Microfilm Edition (MIC 192, Roll 13) Ohio Historical Society, Columbus; Finkelman, "Prigg v. Pennsylvania and Northern Courts," 6.
} 
quickly suppressed his joys and turned them to fear and anxiety. ${ }^{80}$ The new Fugitive Slave Act erased the limitations created by Prigg. Aggrieved slaveholders were no longer wholly dependent upon federal authorities to recover their escaped chattel. However, closing the loophole was only part of the new act. The 1850 law offered financial incentives for recovering lost or escaped chattel:

It shall be the duty of all marshals and deputy marshals to obey and execute all warrants and precepts issued under the provisions of this act, when to them directed; and should any marshal or deputy marshal refuse to receive such warrant, or other process, when tendered, or to use all proper means diligently to execute the same, he shall, on conviction thereof, be fined in the sum of one thousand dollars. ${ }^{81}$

Financial punishments were not the only incentives, it

further enacted, that the marshals, their deputies, and the clerks of the said District and Territorial Courts, shall be paid, for their services ... entitled to a fee of five dollars each for each person he or they may arrest, and take before any commissioner. ${ }^{82}$

Perhaps most threatening to Liberians, was the portion of the act that allowed private citizens to assist in the recovery of lost chattel, and punished those who hindered recovery. On the one hand, Kid Walter and John Mitchell were legally free to assist authorities and could help sell their neighbors into bondage. But, if other neighbors like Doc Brown, attempted to assist Liberians and authorities caught them, they faced heavy fines, like those imposed on Robert Mitchell in $1853 .{ }^{83}$ Liberians found themselves

${ }^{80}$ Dr. William Edwards became a black refugee in 1848, and despite two attempts to capture him he found his way to Mercer County. Dr. William Edwards to Wilbur Siebert, 3 August 1895, Wilbur H. Siebert Collection, Microfilm Edition (MIC 192, Roll 13) Ohio Historical Society, Columbus.

${ }^{81}$ An Act to amend, and Supplementary to, the Act entitled "An Act respecting Fugitives from Justice, and Persons escaping from the Service of their Masters, " U.S. Statutes At Large 9, chapter LX, 462 (1850).

${ }^{82}$ Ibid.

${ }^{83}$ Ibid. 
exposed and nearly defenseless, the security and refuge they once enjoyed in Mercer County was lost. The legislation literally hit close to home when

A runaway slave who was hiding with them was captured and taken back to slavery. This with several other attempts so frightened the community that they sold out or gave away their farms and went to Canada in a body. ${ }^{84}$

Only three Liberians remained after these incidents, Sydney Polk, Auntie Strange, and John Mitchell. Sydney Polk was pregnant and unable to make the long journey to Canada. She moved in with a doctor in West Middlesex. The doctor delivered her baby and hired her as a housekeeper for his household. Auntie Strange was either too frail or too exhausted to make another journey as a refugee. Before her arrival in Liberia, she had escaped and been recaptured twice; the prospects for another flight undoubtedly weighed heavy upon her. John Mitchell stayed behind apparently unafraid of the new legislation, after all he had previously profited from assisting slave-catchers. The Fugitive Slave Act of 1850 brought an end to Liberia, and the Underground Railroad route that went through the community. However, the act did not entirely eradicate the sanctuary offered by Mercer County. In 1854, a second refugee community emerged in the southeastern corner of the county. ${ }^{85}$

\footnotetext{
${ }^{84}$ Unidentified Letter to Wilbur Siebert, 25 November 1895, Wilbur H. Siebert Collection, Microfilm Edition (MIC 192, Roll 13) Ohio Historical Society, Columbus. ${ }^{85}$ Ibid; "Liberia - Now Stoneboro - Was Slaves' Refuge," The Sharon Herald (1965); and Joseph Polk, Stoneboro, interview by William Hunter, 25 May 1946, Folder \#8, "Negro Settlement," William Hunter Collection; Mercer County Historical Society, Mercer, PA
} 


\section{CHAPTER 4}

\section{PECULIAR CONFLICTS}

Nothing is more certainly written in the book of fate than that these people are to be free ... The hour of emancipation is advancing, in the march of time ... it will come ... It is still in our power to direct the process of emancipation and deportation peaceably.

- Thomas Jefferson

Even though blacks no longer felt safe in Liberia and abandoned their settlement by 1851 , the flow of black refugees into Pennsylvania and other northern states continued. For enslaved blacks who sought their emancipation through escape, northern states were no longer a final destination as much as they were a way station; for those who escaped bondage, Canada offered the best chance at freedom. However, other newly emancipated blacks found themselves living as refugees and continued to settle in northern states, including Pennsylvania. The peculiar institution of slavery created a peculiar set of problems for lawmakers in slaveholding states. Slaveholders sought to control not only their own chattel but also the direction and tempo of any proposed emancipation schemes. While lawmakers debated how best to regulate slavery and emancipation, particularly in Virginia, slave insurrections at home and abroad fed a burgeoning fear of blacks. This Negrophobia prompted some whites to force blacks out of their homes and left them searching for refuge in less hostile regions.

Once again, Mercer County, Pennsylvania offered a new home for southern blacks seeking refuge. In 1854, a second black refugee settlement appeared just south of the borough of Mercer. The journey for these settlers began years before. Indeed, slave

\footnotetext{
${ }^{1}$ Paul Leicester Ford, The Writings of Thomas Jefferson (New York: G.P. Putnam's Sons, 1905), Vol. I, p. 68 and Vol. X, p. 292.
} 
codes in Virginia helped seal their fates before many were even born. To understand the context of the new settlement of blacks in Mercer County, as well as to demonstrate the hypothesis that they were refugees, it is important to survey the changing nature of manumission in Virginia in the first half of the nineteenth century. This chapter, then, examines the origins of the second black settlement in Mercer County by recounting the context and circumstances of their emancipation.

In December of 1854, nearly fifty refugees left their homes outside of Charlottesville, Virginia, and over the course of several weeks journeyed by train, canal boats, and wagons to their final destination south of Mercer Borough to an area called Indian Run. The death of Dr. Charles Everett in 1848 set events in motion that displaced the black refugees and forced them to look outside of Virginia for refuge. Everett's will emancipated his enslaved blacks and provided monetary support for their removal and relocation outside of Virginia. Six years earlier, the near fifty black refugees lived in bondage, the property of Everett, M. L. Walker, F. K. Nelson, F. G. Ruffin, W. M. Smith, and Charles Bankhead. Everett claimed the majority of the enslaved blacks; the others were family members claimed by Walker, Nelson, Ruffin, Smith and Bankhead. ${ }^{2}$

At some point, local residents of Mercer County began referring to the Indian Run settlement as Pandenarium, although the origins of the name are not entirely clear. Nineteenth century accounts of the settlement efforts consistently refer to it as the black settlement near Indian Run. There is no evidence that either the settlers or their neighbors referred to the settlement as Pandenarium; printed references to that name do

\footnotetext{
2 "Emancipated Slaves," The National Era, 7 December 1854. Will Book, No. 3, pp 331 - 335 and Fiduciary Book, No. 1, pp 69 - 70. Albemarle County Courthouse, Charlottesville, VA.
} 
not appear until well into the twentieth century. The blacks who settled around Indian Run did not settle into a village or town; rather the area they settled stretched over several townships and the borough of Mercer.

Nonetheless, the name Pandenarium probably is not merely coincidence. Local history claims the name had Biblical significance but, Pandenarium does not exist in the English language reference works. Instead, the name is probably a derivation of Paddan Aram. Paddan Aram refers to the high plains of Aram, in present-day south central Turkey of which the city of Harran is a part. Although Mercer County is part of the Allegheny Plateau, the settlers of Pandenarium were probably not referring to its topography. Rather, for them the significance of Paddan Aram and Pandenarium had more to do with cultural rather than with physical geography. In the Old Testament, Paddan Aram was the place to which Jacob fled. Jacob stole his older brother's birthright and later a blessing from their father, Isaac. Fearing the wrath of Jacob's brother Esau, their mother Rebekah convinced Jacob to flee and seek refuge with her family in Paddan Aram. Jacob effectively became a refugee, staying with his mother's family until his brother's anger waned. For Mercer's black settlers the parallels between Jacob's plight and their own may have given them a measure of hope in their new home. Like their Biblical predecessor, the black settlers found themselves driven from Virginia by fear. And while their benefactor was not a parent, there is no denying the patriarchal designs of chattel slavery in America. Indeed, the deceased slaveholder made provisions for his former servants to relocate in friendlier confines. ${ }^{3}$

\footnotetext{
${ }^{3}$ Genesis, chapters $26-33$, recounts the story of Jacob betraying his brother, deceiving their father, and his subsequent exile in Paddan Aram. Gail Habbyshaw and Rachel Darby, ed. "Follow the Drinking Gourd: Walking Tour of Mercer's Historic
} 
In October of 1848, Dr. Charles Everett quietly passed away at his home in Charlottesville, Virginia. At his side was his nephew and namesake, Charles Denny Everett. The elder Everett, died a bachelor, and his only heirs were his nieces and nephews. His passing undoubtedly elicited a measure of sadness and remorse in the community, since Everett had served Charlottesville in various capacities over the course of his life. For the nearly fifty slaves of Everett's plantation his passing also signaled a chance at a new life. Before his death Everett named his nephew and namesake executor of his estate. This held obvious benefits for the younger Everett since he inherited his uncle's Belmont Plantation. In his will, Everett emancipated all of his slaves and left nearly $\$ 35,000$ to provide for their relocation and re-settlement outside of Virginia. In his final days, Everett was uncertain as to how distribute his legacy and he was equally uncertain about where to place his enslaved chattel. Everett wrote his original will on 27 September 1848; in it, he directed the executor to divide his estate among his nieces and nephews, with his namesake receiving a two-thirds share. Everett directed his heirs to remove and relocate his enslaved chattel in Africa, "for the enjoyment of their liberty." The only proviso was that they had to continue to work for an additional five years under the terms of the will.

Three days after his original will, Everett changed his mind for reasons that remain unclear. On 30 September 1848, Everett revised his will and ordered that his namesake inherit the whole of his estate. Although he still wished his slaves

Underground Railroad and Abolitionist Era Sites," Mercer County Historical Booklets, MCHS Booklet \#2 (Mercer, Pennsylvania: Mercer County Historical Society, 2002), p. 15; W. Edward Weidhmann, "Indian Run History Compiled by Educator," The New Wilmington Globe, 23 August 1973; and Lillian Reeher, "Anti-Slavery at Indian Run Began at Neshannock Church," Wolf Creek Legacy II, 67, Mercer County Historical Society; Mercer, Pennsylvania. 
emancipated, his revised will directed his nephew, "to remove [his] slaves where he may think it best for them." ${ }^{4}$ He kept the condition that they work on the plantation for another five years after his death, which is the reason that they did not leave for Pennsylvania until 1854. This condition in his will should not be viewed as surprising or unusual; many post-mortem emancipations were gradual. Sometimes, the revenues generated by their continued labors defrayed the relocation and resettlement expenses. In other cases the deceased wished their chattel to continue to serve their surviving spouse until his or her demise. ${ }^{5}$ Obviously, Everett had little concern for a spouse, but it is likely that his nephew used some monies from their continued bondage to remove and relocate them in Pennsylvania.

As was perhaps his intention, Everett's posthumous manumission of his slaves has led some to interpret his actions as a benevolent man who cared deeply for the welfare of his enslaved blacks, and did not wish harm to befall them upon his demise. ${ }^{6}$ In fact, Everett may well have cared for all parties involved deeply, but other evidence suggests that this might have been out of character for Everett and that he may have had less than loving motivations in his decision making process. The doctor was a welleducated and well-connected man; he studied medicine under Benjamin Rush at the

\footnotetext{
${ }^{4}$ Last Will and Testament of Charles Everette, Will Book, No. 2, 107 - 108, Albemarle County Courthouse; Charlottesville, Virginia.

${ }^{5}$ Eric Durin, Slavery and the Peculiar Solution: A History of the American Colonization Society, (Gainesville: University of Florida Press, 2005), $54-55$.

${ }^{6}$ Catherine Coleman Seaman, A History of Southern Rockfish Families and Old Houses (Lovington, VA: Nelson County Historical Society, 1990), 27; "Emancipated Slaves," The National Era (7 December 1854); Hubert Rex Johnson, A History of the Neshannock Presbyterian Church, (Washington, D.C.: National Capital Presbytery Inc., 1925), 229 232.
} 
University of Pennsylvania. ${ }^{7}$ After graduating, Everett moved to the Charlottesville, Virginia, area. There, he set himself up as a successful physician, counting Thomas Jefferson and James Monroe as his patients. ${ }^{8}$

Everett's education and connections soon made him a prominent figure in Charlottesville society. Several prominent families turned to him to support and educate their children. His neighbor, Francis Walker, appointed the doctor to be executor of his estate and named him guardian of his two daughters, Judith and Janie. The young girls were not the only children left to Everett's tutelage; George, Francis and Peachy Gilmer, and Meriwether Lewis were all students of Dr. Everett. Two of the Gilmer brothers remember Charles Everett as a less than pleasant teacher. ${ }^{9}$ Of his time under Everett's direction, Peachy Gilmer recalled:

The first teacher of whom I have any distinct recollection was Dr. Charles Everette, since for many years an eminent physician in Albemarle and the adjoining country. He was during that period of his life afflicted with very bad health, of an atrabilious and melancholy temperament: peevish, capricious, and every way disagreeable. I found a dislike to him which I have never been able to wholly overcome. He invented cruel punishments for the scholars, one of which was inflicted by raising a three legged stool on stones placed against the wall of the house, setting two of the legs on them, and propping the other leg with a stick under it, so as to make it a trap; the offender was placed upon the stool, and he stalked backward and forward near him; and when he caught him off his guard, he kicked out

\footnotetext{
${ }^{7}$ W. J. Maxwell, General Alumni Catalogue of the University of Pennsylvania, (The Alumni Association of the University of Pennsylvania, 1922), 503.

8 “Letters of James Monroe," Tyler's Quarterly Historical and Genealogical Magazine 4 (1922), 96; Edward C. Mead, Historic Homes of the Southwest Mountains of Virginia, (J.B. Lippincott Co., 1898), 78; and Norman Schneeburg, "The Medical History of Thomas Jefferson (1743 - 1826)," Journal of Medical Biography, Volume 16, No.2 (2008), $118-125$.

${ }^{9}$ Mead, 78; Robert Louis Everett, The Everetts of Albemarle County Virginia, (Riverside, CA: Canyon Crest Printing, 1992), 22 - 23 and Peachy Gilmer as quoted in Richard Beale Davis, Francis Walker Gilmer: Life and Learning in Jefferson's Virginia, (Richmond, VA: The Dietz Press, 1939), 360 - 361.
} 
the prop, and threw him prostrate on the floor. ${ }^{10}$

Everett's students were not the only persons to incur the ill temperament of the doctor. On more than one occasion, the doctor feared some of his neighbors sought to relieve him of his money by foul means. Such paranoia affected even Everett's romantic relationships. For instance, following her husband's death, Francis Walker's widow appreciated the care Everett showed her daughters and herself. Appreciation turned to affection and the widow Walker and Dr. Everett briefly started a romance. The couple even made plans for a wedding, but Dr. Everett's financial fears overtook him and he cancelled the wedding. He believed that Mrs. Walker was only interested in his money and consequently ended the relationship entirely. Years later, another woman became interested in the distinguished bachelor, and the doctor seemed amenable to her advances. The woman was excited when she received a small jeweler's box from the doctor, but joy soon turned to frustration when she opened the box to discover a shriveled black pear with a note reading, "Emblematic of the donor's heart." ${ }^{\text {"11 }}$ The surviving stories of Dr. Everett put him in a Dickensian light, portraying him as a real life Ebenezer Scrooge. He made decisions and took actions for his own reasons and any attempts to gain access to his personal wealth were apparently unwelcome. Since Charles Everett was not overly trusting of people, even those close to him it is hard to imagine him as a man who treated his slaves with great kindness.

How, then, do we account for Everett's will, which emancipated and provided support for his enslaved blacks? Dr. Everett's distrustful, and sometimes vindictive behaviors are not the only reasons to suggest that his will had less to do with a heavy

\footnotetext{
${ }^{10}$ Davis, $360-361$.

${ }^{11}$ Everett, $23-25$.
} 
heart. Politically, Charles Everett was one of a number of slaveholding Whigs, and he offered little evidence that he was terribly aggrieved by the existence of slavery. Any personal sentiments are difficult to discern, without extant papers or letters. However, some scattered correspondence of Everett's friends and close associates perhaps can shed some light on Everett's feelings on slavery and enslaved blacks. Correspondence between Everett and James Monroe offers clues about where the doctor stood on slavery. Writing to Everett in March of 1812, Monroe discussed a recent lawsuit between himself and Thomas Brand. Brand had rented enslaved chattel from Monroe, and during the time they were under his control he beat one enslaved black so severely that the man required medical attention and his value as chattel declined. Even aside from the monetary considerations, the event troubled Monroe, causing him to declare: "The God who made us made the black people, and they ought not to be treated with barbarity." ${ }^{12}$ In the resulting lawsuit, Monroe declined any monetary compensation. Instead he found solace in the fact that, "the just sentiment expressed by a respectable jury, while although they assisted in no sense, was decided against such an act, affords me great satisfaction." ${ }^{13}$ A later letter from Monroe was even more telling,

Something like an example seemed to be the proper, or at least that I should show my disapprobation of his [Brand's] conduct, by suing him, whatever might be the result. As to my compensation for the loss of him [Monroe's enslaved chattel], I do not even think of it, nor is it my wish that anything be given to the fellow. ${ }^{14}$

\footnotetext{
12 James Monroe to Charles Everett, 23 March 1812 in, "Letters of James Monroe," Tyler's Quarterly and Historical Genealogical Magazine 4 (1922), 107.

${ }^{13}$ James Monroe to Charles Everett, 23 March 1812.

14 James Monroe to Charles Everett, 25 April 1812 in Tyler's Quarterly and Historical Genealogical Magazine 4 (1922), 107.
} 
A couple of things stand out in Monroe's letters that hint at Everett's attitudes. In both letters to Everett, he gave his friend "full authority" in the case "to adjust it as you think fit."15 Monroe's intention was "to leave it to [Everett] to settle the affair.",16 Clearly, Monroe had full faith in Everett's abilities and judgment on the matter. It is not too great a stretch to assume that Monroe believed that he and his friend, Charles Everett, were of like or similar mind on such matters. James Monroe's response to the situation seems very much in line with how Everett may have responded were it his slaves that Brand damaged. The emphasis for Monroe and most likely for Everett as well, was teaching Brand a lesson.

There are still other examples of the close bond between the two men and the degree of influence Everett held with James Monroe. During Monroe’s presidency, one of Everett's former pupils, Francis Gilmer, sought political appointment as the Secretary of State in the Florida territory. Gilmer and his tutor quarreled off and on over the years and in 1821, he found Everett standing in the way of his political aspirations. In a letter from William Wirt to Francis Gilmer, Wirt advised

That Everett may have lodged some unfavorable impression of you in his mind [Monroe] - for he is much under the influence of those whom he considers honorable and judicious and who are devoted to him ... I make the inference from E's hostility to you and the intimate footing on which he stood with Mr. M. ${ }^{17}$

The bond between Everett and Monroe, and the former's influence on the latter was such that it is safe to surmise that both men may have shared similar thoughts on slavery and the resulting dilemmas it created.

15 James Monroe to Charles Everett, 23 March 1812.

${ }^{16}$ James Monroe to Charles Everett, 25 April 1812.

${ }^{17}$ William Wirt to Francis Gilmer, 29 January 1821 in Beale, 147. 
In any event, Everett's thoughts on slavery, manumission and their consequences were in keeping with many of his Virginian and southern contemporaries. His thoughts were shaped by the debates and events that he and his close friends and associates witnessed in the first half of the nineteenth century. Chattel slavery created enormous contradictions south of the Mason and Dixon Line. For instance, in a letter to John Holmes, Thomas Jefferson commented on the conflict between revolutionary ideology and slavery: "We have the wolf by the ears; and we can neither hold him nor safely let him go. Justice is on one scale and self preservation on the other." ${ }^{18}$ Lawmakers, jurists, and slaveholders alike understood the problems they confronted and did not glaze over them lightly.

One man, St. George Tucker, a noted Virginia jurist, wrote at some length about the conflicts and their resultant debates. His Dissertation on Slavery, mapped out the problems of mass emancipation. Tucker, like his peer Thomas Jefferson, believed the abolition of slavery was inevitable - it was simply a matter of time. Rather than sit by placidly waiting for abolition to arrive, Tucker advocated taking an active role in dictating the means and modes of the process. Like Everett, Tucker knew there was a price tag affixed to emancipation. Everett looked simply to the cost of relocating and resettling his enslaved chattel in another corner of the world. He need only concern himself with his own property, but Tucker looked at the broader problem of ending slavery: "A great part of the property of individuals consists in slaves ... can the laws take away the property of an individual without his own consent, or without just

${ }^{18}$ Thomas Jefferson to John Holmes, 22 April 1820, Ford, Vol. X, 157 - 158. 
compensation?"19 Tucker understood that mass emancipation took away significant capital vested in the form of enslaved chattel. The prospect of losing a significant portion of their propertied wealth without some form of compensation did not excite many wealthy slaveholders.

St. George Tucker believed there were only two ways to generate the funds necessary to compensate Virginia's slaveholders. The first involved imposing a general tax, which would generate the revenues that the state could use to compensate slaveholders for their losses. Taxation, however, was fraught with pitfalls. Moreover, the state compensation accounted for the loss of property but failed to account for the loss in revenues resulting from a loss of labor. Presumably, the state would set a valuation on enslaved chattel, perhaps the going market rates; in any case, these valuations were more subjective and bound to upset more than one slaveholder. Perhaps most importantly Tucker asked, "will those who do not hold slaves agree to be taxed to make this compensation?"20 Although slavery existed throughout Virginia, the heaviest concentration of enslaved chattel was in the eastern portion of the state; while residents of western Virginia had less invested in enslaved chattel the state would still expect them to contribute to its coffers. Any proposal to increase taxes to benefit the wealthier property holders in the east would probably not have gone over well in the Valley and Mountain regions of the west.

Compounding the antagonism of the tax proposal was the general lack of political voice for western Virginians. Like slavery itself, political representation favored the

${ }^{19}$ St. George Tucker, A Dissertation on Slavery with a Proposal for the Gradual Emancipation of It, in the State of Virginia, (Philadelphia: Matthew Carey Publisher, 1861 reprint edition), 79 .

${ }^{20}$ Ibid. 
Tidewater and Piedmont regions not the Valley and Mountain regions of the west. This parallel was hardly a coincidence; suffrage in Virginia depended largely upon property holding and to a lesser degree taxpaying. ${ }^{21}$ The political apportionment of antebellum Virginia allocated 19 of the commonwealth's 32 senators to the Tidewater and Piedmont regions. Representation in the General Assembly was no better, 78 of the 134 members came from the Tidewater and Piedmont. These regional discrepancies prompted historian Craig Simpson to declare that, "the Old Dominion was not a politically democratic community.,22

Taxation, then, seemed an unrealistic method for funding emancipation according to Tucker. A better method he believed was generating the compensation from the bondspeople themselves. Under this plan, Tucker posited that enslaved chattel could work for the state or individual slaveholders to generate the revenues necessary for compensation. Following Pennsylvania's model of gradual abolition, he proposed that after a specified date all black children born to enslaved mothers,

serve such persons until the age of twenty-eight years; let them then receive twenty dollars in money, two suits of clothes, suited to the season, a bat, a pair of shoes, and two blankets. If these things be not voluntarily done, let the county courts enforce the performance, upon complaint. ${ }^{23}$

This gradual process reduced the financial trauma upon slaveholders, and provided a means to abolish slavery without taxing those unwilling or unable to support the institution. What Tucker ignored was the potential for abuse in his proposal. His was,

\footnotetext{
${ }^{21}$ Charles S. Sydor, The Development of Southern Sectionalism, 1819-1848, (Baton Rouge, Louisiana State University Press, 1948), 286.

${ }^{22}$ Craig Simpson, "Political Compromise and the Protection of Slavery: Henry A. Wise and the Virginia Constitutional Convention of 1850 - 1851," The Virginia Magazine of History and Biography, Vol. 83, No. 4, (October 1975), 387 - 388.

${ }^{23}$ Tucker, 89.
} 
after all, a proposal for indentured servitude. It required that slaveholders comply with the intentions of gradual abolition. The gradual process used in Pennsylvania and adopted by Tucker's proposal was painstakingly slow for enslaved blacks.

Clearly, for Tucker, the welfare of blacks was a tertiary concern at best and at worst not a concern at all. According to the jurist, Virginia's "security, nay, our very existence, might be endangered by the hasty adoption of any measure for the immediate relief of the whole of this unhappy race. ${ }^{24}$ His only interest in the welfare of Virginia's free black population occurred at the intersection of self-interest and state security. Tucker dispelled any notion that his proposal was born of benevolent philanthropy when he declared: "let me avoid the imputation of inconsistency, by observing, that the abolition of slavery may be effected ... without the emancipation of a single slave." ${ }^{25}$

Tucker opposed any mass emancipation of enslaved chattel in Virginia. The pecuniary losses were of course, debilitating to slaveholders like himself. But, Tucker worried about ancillary costs not readily apparent on balance sheets. Referencing the recent slave insurrection and subsequent revolution in Saint Domingo, he believed the presence of a large free black population could cost society as a whole:

To retain them among us, would be nothing more than to throw so many of the human race upon the earth without a means of subsistence: they would soon become idle, profligate, and miserable ... to discharge [slaves] from their present condition, would be attended with an immediate general famine. ${ }^{26}$

\footnotetext{
24 Ibid., 80.

25 Ibid.

${ }^{26}$ Ibid., $77-78$.
} 
If fears of famine and a listless black population were not enough to stir action, Tucker also suggested that blacks would become predatory members of society becoming, "the tigers of the human race. ${ }^{27}$

St. George Tucker understood that his proposed gradual abolition released free blacks into Virginian society, if only at a slower pace than immediate emancipation. The "proportion of slaves," he recognized was "too great not to be attended. ${ }^{, 28}$ He was not keen on living alongside free blacks, although Tucker claimed he was "opposed to the banishment of the Negroes." ${ }^{29}$ In order to encourage free blacks to leave Virginia, Tucker advocated stripping them of all civil rights. ${ }^{30}$ So draconian were Tucker's encouragements that historian Alison Freehling asserted that his "solution to the racial dilemmas of emancipation involved the uncompromising repression of freedmen."31 Whether they gained freedom through emancipation or gradual abolition, Tucker like many of his peers, believed free blacks were a threat to the peace of Virginia.

No matter the solution, emancipation or abolition, lawmakers and residents in slave states consistently confronted the query, what to do with free blacks? Although the

\footnotetext{
${ }^{27}$ Ibid., 77.

${ }^{28}$ Ibid., 78.

${ }^{29}$ Ibid., 92.

${ }^{30}$ Tucker proposed that, no Negroe or mulattoe be capable of taking, holding, or exercising, any public office, freehold, franchise or privilege, or any estate in lands or tenements, other than a lease not exceeding twenty-one years.-Nor of keeping, or bearing arms, unless authorized so to do by some act of the general assembly, whose duration shall be limited to three years. Nor of contracting matrimony with any other than a Negroe or mulattoe; nor be an attorney; nor be a juror; nor a witness in any court of judicature, except against, or between Negroes and mulattoes. Nor be an executor or administrator; nor capable of making any will or testament; nor maintain any real action; nor be a trustée of lands or tenements himself, nor any other person to be a trustee to him or to his use, 91.

${ }^{31}$ Alison Goodyear Freehling, Drift Toward Dissolution, (Baton Rouge: Louisiana State University Press, 1982), 94.
} 
price tag of mass emancipation may have been too steep for the state, that did not preclude private individuals from emancipating their own enslaved chattel. Persons like Charles Everett used his will to manumit his slaves. However, he recognized that releasing his former bondspersons into Charlottesville without support would likely have had disastrous consequences for the nearly forty individuals. Although they were healthy when emancipated according to court records only four, had any formal trades. ${ }^{32}$ Their status upon emancipation, on the surface at least, confirmed St. George Tucker's fears of emancipation. Without homes, land, or sources of income these people risked becoming the "tigers" of the Charlottesville area. Any claim that these persons would turn to crime if left without support is conjecture, although some did run a foul of the law after their relocation in Pennsylvania. ${ }^{33}$ However, many whites believed as St. George Tucker that, "These people, accustomed to be ruled with a rod of iron, will not easily submit to milder restraints. They would become hordes of vagabonds, robbers and murderers."”34

Everett was not alone in his posthumous manumission of his chattel. Other slaveholders in Virginia used their wills to free enslaved blacks from bondage. Perhaps most prominent among these others was John Randolph, who freed several hundred enslaved blacks posthumously. Historian Eric Durin suggests that posthumous emancipators "believed that the enterprises [manumissions] would enhance their post mortem reputations. Eulogists and former bondpersons ... would surely praise their

\footnotetext{
${ }^{32}$ Fiduciary Book 1, Albemarle County Courthouse, Charlottesville, Virginia, 69; Will Book, No. 23, Albemarle County Courthouse, Charlottesville, Virginia, 327 - 341

${ }^{33}$ Mercer County Quarter Sessions, Book 7, August 1863 to April 1869, 290 - 291 and 414, and Mercer County Quarter Sessions, Book 8, April 1869 to February 1873, 161; Mercer County Courthouse, Mercer, Pennsylvania.

${ }^{34}$ Tucker, 84.
} 
memory. ${ }^{, 35}$ This proposition certainly seems likely in the case of Dr. Everett. What little has been written of the man presents him as a very kindhearted slave owner, a characterization very much at odds with the evidence we have of his personality. Still slaveholders like Everett and Randolph did not release their chattel upon their neighbors without some planning; these men directed their heirs to relocate their former chattel outside of Virginia.

Although St. George Tucker's dissertation was detailed in its explanation of the problems of slavery and emancipation in Virginia, his ideas did not carry the weight of law in 1796; as such, they simply a suggested how to deal with the issues of race and slavery. In Tucker's dissertation however, historians can find the roots of the Virginia Colonization movement and the origins of the state's 1806 slave codes, which banished emancipated blacks from the state and stripped them of civil rights. Private manumissions, although less common then posthumous manumissions, continued across the state. While the state frowned upon emancipation, lawmakers did little to curtail the practices of private individuals. Not until Virginia's General Assembly realized its worst fears did they take more comprehensive action on regulating manumissions and free blacks. Three slave uprisings occurred between 1797 and 1800, each seemingly growing larger in scope and each successive one occurring closer to the state capitol in Richmond. ${ }^{36}$ The successful slave insurrection and revolution in Saint Domingo compounded these local events. Prompted by these frightening uprisings, lawmakers reconsidered adopting Tucker's ideas as potential legal codes.

${ }^{35}$ Eric Durin, Slavery and the Peculiar Solution: A History of the American Colonization Society, (Gainesville: University of Florida Press, 2005), 54.

${ }^{36}$ Herbert Aptheker, American Negro Slave Revolts, (New York: International Publishers, 1983), 219. 
A year after Tucker published his Dissertation on Slavery, a seemingly spontaneous insurrection occurred in Prince William County in 1797. Enslaved blacks from several plantations gathered for a dance in the slave quarters of Colonel Alexander's plantation. The Colonel, apparently lenient, "pampered and indulged his slaves," and raised little objection to a dance. ${ }^{37}$ While the Colonel had no objections, the same was not true of his neighbors. A local patrol rode throughout the area that night looking for enslaved blacks without passes from neighboring plantations. When the patrol happened upon the noise of the dance, they decided to raid the festivities and round up the revelers. A look out from the dance unwittingly guaranteed confrontation when he spotted the approaching patrol. At least twenty-five resolute blacks decided they would not succumb to the patrol's efforts. After putting out all the lights, the blacks waited in silence and ambushed the slave patrol, killing two whites. Although spontaneous in nature, this uprising nonetheless created much consternation in the surrounding white community. Still, its spontaneity did little to stir any immediate action from state lawmakers; taken by itself this was an isolated incident. ${ }^{38}$

Two years later a second, no less spontaneous, uprising occurred in Southampton County. In 1799, slave traders from Georgia arrived in Southampton to purchase enslaved Africans with funds from their partner James Spears, a member of the Georgia state legislature. Even before the traders and their charges left the county, the enslaved

${ }^{37}$ Austin Steward, Twenty Two Years a Slave, and Forty Years a Freeman; Embracing a Correspondence of Several Years while President of Wilberforce Colony, London, Canada West, (Chapel Hill, NC: Electronic edition, http://docsouth.unc.edu/fpn/steward/steward.html, 1997), 35. This work is the property of the University of North Carolina Chapel Hill, and is part of the "Documenting the American South" digitization project.

${ }^{38}$ Ibid, $33-38$. 
blacks overpowered their captors, robbed them, and killed one before fleeing in to the woods. The surviving trader escaped and sought help from local slave patrols. By the time the slave patrols found the escaped blacks, they had armed themselves with sticks, knives, and pistols and most importantly made up their minds not to return to bondage. In the fighting that ensued, the patrol killed ten of the black rebels, and captured another five. ${ }^{39}$ Like the Prince William uprising two years earlier, this event was more of a local problem although its closer proximity to Richmond and the stature of James Spears drew Governor James Monroe into the resultant legal proceedings. Monroe himself reviewed the case against the black rebels as the circumstances, as well as the funding used to purchase them, was of questionable origin. ${ }^{40}$

Both the Prince William and Southampton uprisings generated considerable fears and tensions within their local settings. The Southampton incident drew the attention of the Governor's office not so much because it was a slave uprising but moreso because of the proximity to Richmond and the stature of James Spears. Still, for Virginia's white population these two uprisings must have created some sense of consternation across the state. Even if they were spontaneous in their eruptions Virginians used them as evidence that an insurrection could take place at any time and without any kind of obvious warning.

If the first two generated fear, the third was terrifying for whites and sounded a wake-up call for state lawmakers. Gabriel's Uprising in 1800 did as much as anything to

${ }^{39}$ Arthur Scherr, "Governor James Monroe and the Southampton Resistance of 1799," The Historian, (Spring, 1999), 557.

${ }^{40}$ According to historian Arthur Scherr, the money used to purchase the enslaved blacks in Southampton County resulted from James Spears embezzlement of $\$ 10,000.00$ from the Georgia State Treasury. Scherr, 557. 
fuel the discussion on what to do with Virginia's free blacks. Bondsman Gabriel Prosser encouraged his fellow bondsmen to take up arms and march to Richmond, whereupon they would burn the city and take Governor James Monroe hostage. Gabriel and his coconspirators were defeated and captured, and in the wake of the insurrection the state executed over 30 blacks. The threat of violent insurrection on the capitol doorsteps must have frightened lawmakers terribly. ${ }^{41}$

The three slave insurrections in as many years, each moving successively closer to Richmond, drove Governor Monroe to write to the president. In his correspondence with President Thomas Jefferson, Monroe introduced the idea that the government colonize free blacks outside of the United States. Virginia's already large free black population supported Monroe's concern that free blacks might encourage, if only by their presence, enslaved blacks to revolt. In the wake of the uprisings Monroe became convinced that abolitionists and free blacks were encouraging the violent uprisings. In 1800, the combined free black population of New York, New Jersey, and Pennsylvania was only slightly larger than the free black population of Virginia. The largest concentration of free blacks anywhere in Virginia was in Petersburg, just south of the state capitol. ${ }^{42}$ Petitioners from Dinwiddie County asked state legislators to consider repealing or at least suspending the emancipation of enslaved blacks in Virginia. Their fears prompted them to make a further request when they asked the General Assembly to

${ }^{41}$ J. C. Carroll, Slave Insurrections in the United States, 1800 - 1865, (New York: Negro Universities Press, 1938), 55; and Joyce Tang, "Enslaved African Rebellions in Virginia," Journal of Black Studies, Vol. 27, No. 5, (May 1995), 608.

${ }^{42}$ Scherr, 557 - 578; Philip Slaughter, The Virginian History of African Colonization, (Richmond, 1855), 1 - 2; John H. Russell, The Free Negro in Virginia, 1619 - 1865, (reprint edition New York: Dover Publications, 1969), 9; and Luther Porter Jackson, "Manumission in Certain Virginia Cities," The Journal of Negro History, Vol. 15, No. 3 (July 1930), 279. 
restrict the movement of already free blacks within the state. ${ }^{43}$ The fear of slave insurrections and the state's sizable free black population was the driving force by the legislative efforts of 1805 and 1806.

Virginia newspapers did little to assuage fears; they often recounted tales of monstrosities and used the most horrific embellishments. Historian Philip Schwarz has discussed white fears and the newspapers' broad generalizations, which only solidified existing stereotypes in his work Twice Condemned, noting that newspapers frequently branded black rebels as "brigands," and "banditti." In the aftermath of slave uprisings many whites viewed their black neighbors as monsters and enemies within their midst. ${ }^{44}$ "Virginia's lawmakers and judges, from 1723 to 1865," Schwarz noted, "consistently believed that a conspiracy of slaves to rebel had something in common with a conspiracy of slaves to murder white people." ${ }^{45}$ Still, Schwarz also demonstrates that even with the heightened fears, Virginians were increasingly less draconian in the punishments meted out to enslaved blacks convicted of criminal activity. In the first half of the nineteenth century, he points out, Virginians increasingly used deportation as an effective punishment. $^{46}$

In 1806, the General Assembly responded to the fear of slave insurrections, and reconsidered St. George Tucker's proposals. By year's end, the General Assembly put the repressive conditions, that Tucker proposed to encourage free blacks to leave the state, into action. After 1806, the state gave any newly emancipated bondsperson one

\footnotetext{
${ }^{43}$ Petitions, Dinwiddie County, 11 December 1805 (Virginia Library) found in Jackson, $288-289$.

${ }^{44}$ Philip J. Schwarz, Twice Condemned: Slaves and the Criminal Laws of Virginia, 1705 - 1865, (Union, NJ: The Lawbook Exhange, Ltd., 1998), 267 - 268.

${ }^{45}$ Ibid., 262.

${ }^{46}$ Ibid., $28-29$.
} 
year to leave the state or they "shall forfeit all such rights, and may be apprehended and sold by the overseers of the poor of any county or corporation in which he or she shall be found." ${ }^{\text {47 }}$ If the prospect of the state selling them back into bondage did not "encourage" emancipated blacks to leave the General Assembly heeded more of Tucker's advice and prohibited free blacks from owning or possessing firearms. ${ }^{48}$

The slave insurrections had still other effects on the state legislation; the General Assembly banned any further importation of enslaved chattel into the commonwealth. This new legislation gave local authorities the power to confiscate any imported slaves in violation of the code to sell for "the benefit of the poor of such county or corporation.",49 With attention paid to the executions following the recent slave insurrections, the new legislation also declared that any slave illegally brought into the state who committed a capital crime and sentenced to death, had no value. In other words, the General Assembly let slaveholders know the commonwealth was no longer willing to compensate them for the loss of corrupted property. ${ }^{50}$

Deteriorating relations with Great Britain quickly surpassed the flurry of activity, which led to the passage of the 1806 act. Over the next decade, Virginians became less and less concerned with the relocation of free blacks, so much so that within a few years of the 1806 act lawmakers watered down the measure allowing county courts to grant exemptions to the law; they allowed exemptions for blacks of "extraordinary merit." 51

${ }^{47}$ Samuel Shepherd, The Statutes at Large of Virginia, From October Session 1792, to December Session 1806, Inclusive, Vol. III, (New York: AMS Press Inc.), 252.

${ }^{48}$ Ibid., $274-275$.

${ }^{49}$ Ibid., 251.

${ }^{50}$ Ibid., 252.

${ }^{51}$ Luther Porter Jackson, "Manumission in Certain Virginia Cities," The Journal of Negro History, Vol. 15, No. 3 (July 1930), 290; Revised Code of Virginia, 1819, Vol. 1, 436. 
Luther Porter Jackson argued that value to the community was just as important, perhaps more so, as merit. Blacksmiths, bricklayers, draymen and coopers offered a particular skill set, and therefore had greater value within their communities than someone had with no skills or particular trade. ${ }^{52}$ Historian Melvin Patrick Ely's work on free blacks in his book, Israel on the Appomattox, provides the best example of this parochial lack of enforcement. Ely found that whites neighboring the free black community of Israel Hill did not feel particularly threatened nor were they eager to have their black neighbors expelled..$^{53}$

The state's deferment to local courts also had other benefits; local whites could use the 1806 code to their advantage. They could better control both the free black and enslaved populations in some cases. Jackson pointed out that the 1806 act strained marriages between free and enslaved blacks. An enslaved spouse was unable to follow their emancipated partner out of the state. As the state deferred jurisdiction to local courts, local whites used the potential threat of splitting a family to reign in potential threats from either enslaved or free blacks. ${ }^{54}$

It is all too easy to cast the South as an oppressive slaveholding monolith. In Israel on the Appomattox, Ely demonstrates how far from the truth the Southern monolith was. Despite the 1806 legislation, Some Virginia slaveholders continued to manumit their enslaved chattel, and even within this repressive atmosphere free blacks continued

\footnotetext{
52 Although Porter made his argument over seventy years before Israel on the Appomattox, Ely's research supports Jackson's premise; many of the free blacks studied by Ely worked in skilled trades. Jackson, 299 and Melvin Patrick Ely, Israel on the Appomattox, (New York: Alfred A. Knopf, 2004).

${ }^{53}$ Ely, $144-174$.

${ }^{54}$ John H. Russell, The Free Negro in Virginia, 1619 - 1865, (reprint edition New York: Dover Publications, 1969), 132 - 133.
} 
to live and thrive within the commonwealth. The enforcement of the 1806 codes was lax and reflected the ebb and flow of white fears of slave insurrections. As the Prince William, Southampton, and Gabriel's uprisings faded into memory, many judges in the commonwealth became ambivalent toward the black codes. ${ }^{55}$ Ely's study of free blacks in antebellum Virginia points out "that what free black people accomplished came about in part because the society in which they lived ... afforded room for them to act and achieve."56 On at least two occasions, the General Assembly revisited the codes and amended them. The first modification came in 1815 and allowed blacks of "extraordinary merit" to stay if local authorities granted permission. The watering down of the 1806 codes placed the onus upon local authorities. If local whites were amenable to free blacks living within their midst and did not feel threatened the new amendments gave them the authority to allow it. The free black community of Israel Hill along the Appomattox River that Ely studied benefitted from their white neighbor's feelings of security.

By 1816, efforts to remove free blacks from Virginia had gone from the state level to the county level, and finally to the private sector. The birth of the American Colonization Society (ACS), in December of 1816, spawned a new era for the relocation of free blacks in Virginia. Within the year, state lawmakers passed measures allocating funds for black colonization in Africa; the bureaucratic red tape attached, however, dramatically impeded the dispersal of the funding to nil. ${ }^{57}$ The relative peace and absence of slave insurrections continued to diminish the pressing need to relocate free

\footnotetext{
${ }^{55}$ Scherr, 559.

56 Ely, 438.

${ }^{57}$ Freehling, 118; Acts and Resolutions of the General Assembly of the Commonwealth of Virginia, 1816 - 1817, No. 1, 200.
} 
blacks. State lawmakers remained interested in relocating free blacks, but only on a casual basis. Unless free blacks left of their own volition and via their own means, relocation created an expensive problem. Virginia lawmakers were keenly aware that state assisted efforts would likely draw funding from increased taxes. Support for emancipation efforts rested upon the relocation of blacks out of Virginia, preferably far enough away so as not to create any further problems for the state.

With the advent of the American Colonization Society (ACS), lawmakers believed they found an answer to their peculiar conflicts without increasing taxes. Slaveholders found financial assistance in the ACS; the cost of relocating blacks in Africa was almost prohibitive. To make the venture profitable any given slaveholder had to find enough souls to fill the hold of a ship making the trans-Atlantic voyage to Africa. While some wealthy slaveholders like John Randolph or even Charles Everett owned enough enslaved chattel to fill a ship's manifest, most did not. In such cases where a slaveholder did not own or could not manumit enough enslaved persons to fill a ship, they could turn to the ACS, which in turn pooled the resources of many slaveholders. Although state funding was certainly welcome, the ACS balance sheets did not depend on state legislatures. The ACS depended more strongly upon donations from private individuals. In some instances, the private donations exceeded contributions from the states. ${ }^{58}$

\footnotetext{
${ }^{58}$ In 1856, the "Augustus Graham Legacy," alone allocated $\$ 5000.00$ "for the support of schools in Liberia." Conversely, of the 36 states, which, contributed to the ACS in 1856, 32 of them donated less than the Graham Legacy, American Colonization Society, Fortieth Annual Report of the American Colonization Society, with the Proceedings of the Board of Directors and of the Society, (Washington: C. Alexander, Printer, 1857), 9 and 21 .
} 
One slaveholder, Elizabeth Holderness, made "liberal" provisions, to relocate her enslaved chattel in Africa. Included in her "liberal" provisions was a $\$ 968.00$ donation to the ACS. ${ }^{59}$ In Albemarle County, Virginia well-to-do women held a "Ladies Colonization Fair," in Charlottesville to raise funds in support of local and national colonization efforts. The local newspaper declared the fair "a success, which we believe has far surpassed the most sanguine expectations or its friends. ${ }^{" 60}$ Even its zeal to characterize the event a success, the paper readily noted that, "We are, at present, unable to state with the desired accuracy, the precise amount of the receipts. ${ }^{\prime 61}$ Even if the ACS never completely solved the peculiar conflicts of slavery, many believed it offered at least a short-term solution. Throughout the first half of the nineteenth century, slaveholders generously donated to the ACS hoping colonization would reduce antislavery activity among free blacks. ${ }^{62}$

Even as the colonization movement gained support, Virginia remained the most committed state in sending blacks to Africa. In 1857, Governor Henry Wise boldly declared that, "Africa gave to Virginia a savage and a slave," but through colonization "Virginia gives back to Africa a citizen and a Christian." ${ }^{33}$ From 1820 to 1856, the Commonwealth sent 3,315 blacks to Africa as part of the ACS relocation program, leading all states in relocating blacks. The second most active state, North Carolina, sent

\footnotetext{
${ }^{59}$ American Colonization Society, Fortieth Annual Report of the American Colonization Society, with the Proceedings of the Board of Directors and of the Society, (Washington: C. Alexander, Printer, 1857), 9.

60 "Ladies Colonization Fair," The Advocate, (14 May 1830).

${ }^{61}$ Ibid.

62 "African Colonization," Pittsburgh Gazette (16 January 1852); Eric Durin, Slavery and the Peculiar Solution: A History of the American Colonization Society, (Gainesville: University of Florida Press, 2005), 10 - 11.

${ }^{63}$ American Colonization Society, Fortieth Annual Report, 8.
} 
1,158 over the same period. ${ }^{64}$ If Virginia was eager to exile blacks from within its borders, it was not as eager to pay for their relocation. The commonwealth's financial commitment to colonization was not quite as strong as its willingness to exile. Between 1834 and 1836, Virginia gave roughly thirteen-thousand dollars to the ACS. ${ }^{65}$ The commonwealth was not unique in its lukewarm financial commitments. By 1856 , donations from Virginia had swelled to an annual ten-thousand dollars; only the state of New York donated more to the ACS that year. ${ }^{66}$

Another slave uprising in the early 1830s sparked greater support for colonization in Virginia. In August of 1831, Nat Turner staged a bloody but unsuccessful slave uprising in Southampton County. The degree of violence and the continued growth in Virginia's free black population again stirred debate among lawmakers in Richmond. Governor John Floyd believed, "Unrestrained fanatics in some of the neighboring states, who found facilities in distributing their views and plans amongst our population either through the post office or by agents sent for that purpose throughout our territory,"67 assisted Turner and his compatriots. Only a year earlier the Mayor of Richmond forwarded a copy of David Walker's tract, Appeal in Four Articles, to Floyd's predecessor Governor William Giles. Along with the Appeal, the mayor attached a letter from Walker himself to Thomas Lewis, a free black man residing in Richmond. ${ }^{68}$

\footnotetext{
${ }^{64}$ American Colonization Society, Fortieth Annual Report, 16.

${ }^{65}$ American Colonization Society, The African Repository and Colonial Journal, Vol. XIII, (Washington: James Dunn, 1837), 49.

${ }^{66}$ American Colonization Society, Fortieth Annual Report, 21.

${ }^{67}$ John W. Cromwell, “The Aftermath of Nat Turner's Insurrection,” The Journal of Negro History, Vol. 5, No. 2, (April 1920), 218.

${ }^{68}$ William B. Giles to Linn Banks, (7 January 1830); Virginia Executive Communications, Box 37, Virginia State Library; Richmond, VA.
} 
At the time of Turner's revolt the black population in Southampton County totaled 9,501 of which 1,745 were free blacks. The white population in the county only totaled 6,573. ${ }^{69}$ Turner's revolt created a general sense of Negrophobia in Virginia:

The horrors that have taken place in Southampton have aroused my fears ... and indeed ... increased them to the most agonizing degree ... my most torturing imagination had never conjured up anything so terrifick (sic) as this unpitying and horrible slaughter, and the very excitement and appalling precautions which it is thought necessary to take even up here, added to the vague and I believe false rumours (sic) . . keep up my fears ${ }^{70}$

Because of these fears, lawmakers convened a constitutional convention. At the center of the constitutional debates was how to regulate the state's still growing free black population. The ACS enjoyed a resurgence of support for African colonization following Turner's revolt and the resultant state constitutional convention. ${ }^{71}$

Virginia lawmakers continued to debate black relocation as an answer to slave insurrections throughout the 1840s and 1850s. In 1853, legislators introduced two proposals for removing free blacks from the state. The first came from King George County, and suggested that the state hire out free blacks, much like slaves, for a period of five years. At that time, the state could use any monies accrued from their labors to pay for their removal. For free blacks who refused to participate, the state held the right to sell them into bondage and deposit the profits from such sales into the state treasury. ${ }^{72} \mathrm{~A}$ second milder proposal later emerged "looking, however, to the same end - the expulsion

${ }^{69}$ Henry I. Tragle, The Southampton Revolt of 1831: A Compilation of Source Material, (Amherst: University of Massachusetts Press, 1971), $14-15$.

${ }^{70}$ Jane Randolph to Sarah Nicholas, Undated, in Freehling, 6 - 7.

${ }^{71}$ Philip Slaughter, The Virginian History of African Colonization, (Richmond, 1855), 18 - 19; Philip Staudenraus, The African Colonization Movement, 1816 - 1865, (New York: Columbia University Press, 1961), 178; Alison Goodyear Freehling, Drift Toward Dissolution, (Baton Rouge: Louisiana State University Press, 1982), 120 - 121.

72 "Free Negroes," The Richmond Whig, (25 January 1853). 
of the [black] race., ${ }^{, 73}$ Although the state continuously debated the removal of free blacks throughout the early nineteenth century, the only legislative success remained the 1806 act, which strongly encouraged free blacks to leave the state. Even then, subsequent legislation reduced the persuasive efforts of the measure.

Thus, when Dr. Charles Everett died in 1848, he died in a state that supported the colonization of blacks in Africa. The doctor's thoughts and musings on colonization are not entirely clear. Many of his friends and neighbors however, were documented supporters of colonization. Two of his patients, James Madison and James Monroe served as Vice Presidents of the Colonization Virginia of Society. ${ }^{74}$ The doctor's close relationship with James Monroe suggests that he was more than familiar colonization. If his level of influence with Monroe was as peers believed, he shared Monroe's sympathies towards the movement. The level of activity in Albemarle County, Virginia, and Everett's own will indicate that even if he was not a member of any colonization society he was at least sympathetic to their efforts. In little more than a week before he passed away, Everett made out his will and stipulated that the executor relocate his enslaved chattel in Africa. Even when Everett amended his will three days later, he remained clear in his desire to have his former slaves relocated outside of Virginia. ${ }^{75}$

While the decision to manumit and relocate his enslaved chattel was entirely his, Everett's nephew and executor ultimately carried out the task. Doctor Everett had long supported his nephew and put him through medical school at the University of

\footnotetext{
${ }^{73}$ Ibid.

${ }^{74}$ Slaughter, $11-12$ and Staudenraus, 107.

${ }^{75}$ In his original will, Dr. Everett directed his executor, "to have them removed at the end of five years to Africa." Three days later he amended his will to allow the executor to remove his "slaves where he may think it best for them." Will Book, No. 3, 331 - 335; Albemarle County Courthouse, Charlottesville, Virginia.
} 
Pennsylvania. Even in death, Charles Everett supported his nephew naming him executor of the estate and making him sole proprietor of his Belmont plantation. ${ }^{76}$ The parallels between Charles Everett, Sr. and his nephew did not end with their shared profession and ownership of Belmont. Like his uncle, the younger Everett was a bachelor at the time of his mentor's passing. He apparently lived the life of a bachelor to the fullest. He attended operas and plays in Philadelphia, and threw parties and dances for his friends. His attire was in keeping with his stature as young doctor, long capes and beaver skin top hats. $^{77}$

The younger Everett was fortunate to inherit such wealth from his uncle, and his reputation as a playboy made him the most eligible bachelor in Albemarle County since his uncle. On occasion, Charlottesville residents saw him wearing capes lined in scarlet and white top hats. ${ }^{78}$ On his deathbed, the elder Everett cautioned his nephew not to remain a bachelor until his dying day; "it is a dog's life to come home to a cold, dark and lonely house." ${ }^{, 79}$ The younger Everett married four years later in 1852, and started a family shortly thereafter. ${ }^{80}$

His years spent living and practicing in Philadelphia did not sway young Charles Everett in favor of the anti-slavery cause. Although his uncle manumitted his enslaved chattel posthumously, he did nothing to dissuade his nephew from acquiring his own

\footnotetext{
${ }^{76}$ Robert Louis Everett, The Everetts of Albemarle County Virginia, (Riverside, CA: Canyon Crest Printing, 1992),29; Will Book, No. 3, 331 - 335; Albemarle County Courthouse, Charlottesville, Virginia.

${ }^{77}$ Everett, $30-31$.

78 Ibid., 32.

${ }^{79}$ Charles D. Everett, Sr. to his nephew Charles D. Everett, Jr. as quoted in Robert Louis Everett, The Everetts of Albemarle County Virginia, (Riverside, CA: Canyon Crest Printing, 1992), 31.

${ }^{80}$ The Richmond Whig and Public Advertiser, (16 March 1852).
} 
slaves. Within two years of his uncle's death, Everett owned twenty-eight enslaved blacks. By the eve of the Civil War, his enslaved chattel numbered thirty-three blacks. ${ }^{81}$ The younger Everett complied with his uncle's wishes, but his vision of relocation for the slaves of the Everett estate differed markedly from his uncle. He made arrangements to relocate the newly manumitted blacks to western Pennsylvania and not Africa. Cost was probably a factor in his decision, whether the funds allocated by his uncle were insufficient or he saw an opportunity to save some money for himself is unknown. Nevertheless, the expense of shipping nearly fifty free blacks to Africa was not insignificant.

The motivations behind the younger Everett's actions in the manumission of enslaved chattel are less murky than that of his uncle. However, he had no choice in the matter; Virginia's legal system mandated that he comply with his uncle's wishes. Even in the event that he challenged the validity of his uncle's will, he would consequently challenge his status as executor and heir. For the deceased Charles Everett his motivations remain cloudy. He likely espoused the doctrines of colonization and even then his intentions were probably less than philanthropic. In a letter to a friend, Elizabeth Holderness commented on the motivations behind manumission. She questioned the logic of freeing enslaved blacks, "merely for the sake of freedom." "When," she argued, "they will probably be rendered more miserable and unhappy by the change." 82

The personal motivations behind manumission are less important than the systematic motivations behind banning free blacks from Virginia. For the fifty-two

${ }^{81} 1850$ Albemarle County Slave Census, Census Series M432, Roll 983, 201; 1860 Albemarle County Slave Census, M653, Roll 1386, 137.

${ }^{82}$ Elizabeth Holderness to W. McLain, 20 March 1855, "Records of the American Colonization Society," Microfilm edition, (Reel 75, no. 564 1/2 $)$ Library of Congress. 
blacks who gained their freedom from Dr. Everett's death and boarded a train at Keswick Station bound for Pennsylvania in 1854, their futures were no more secure than their Mercer County predecessors who escaped bondage. ${ }^{83}$ They were no less refugees than the settlers of Liberia, Pennsylvania, a decade earlier were. The blacks who ultimately settled the area around Indian Run, later known as Pandenarium, fled the oppression of slavery. Legal codes and local sentiments forced Everett's former chattel out of their homes in central Virginia. They obtained their freedom, but in doing so became enemies of the slaveholding state. The patriarchal structure of chattel slavery in Virginia mandated that slaveholders control the means and modes of emancipation; free blacks threatened that structure. Their very presence threatened to inspire aspirations of freedom among the state's enslaved population. At the same time, their freedom provided them with a measure of self-determination.

There can be no mistake as to the oppression of free blacks in Virginia. Melvin Patrick Ely warns future historians of treating free blacks as the victims of naked aggression at the hands of whites in the antebellum era. However, it is important to note that his cautionary words also entreat historians to examine conditions for blacks on a case-to-case basis. ${ }^{84}$ Whether or not the state successfully expelled all free blacks is almost irrelevant. The fact is that the system of slavery put the structures in place to allow whites to systematically oppress their black neighbors whenever it suited them. The oppression, while systematic, may not have been have been consistent but it was

83 "Emancipated Slaves," The National Era, 7 December 1854; “An Act to Authorize and Empower the Court of Common Pleas of Mercer County to Legitimate Certain Persons who were Emancipated by the Last Will and Testament of Dr. C.D. Everett, late of Albemarle County, Virginia," Laws of the General Assembly of the state of Pennsylvania, of the Session of 1855. No. 324.

${ }^{84}$ Ely, $437-440$. 
constant. The editor of the Richmond Whig responded to the Governor's encouragements to exile free blacks from the state in 1853 ,

There was something malpropre (sic) in the idea of his undertaking to banish from the State a class - many of whom, in all the relations of life, were as respectable and as good citizens as he was himself. But they were not voters - they had no friends - and were, therefore, fit subjects for the unfeeling and tyrannical experiments of demagogues. ${ }^{85}$

The Whig's editor might well have used some yellow journalism to sway the opinion of the paper's readers; however, the editor was not incorrect in branding the relocation of free blacks as tyrannical.

Since we do not know the motivations behind Dr. Charles Everett's posthumous manumission it might be a stretch to brand him a tyrant. However, his desire to see his enslaved chattel removed from the state without any discussion with them placed them on the road to becoming refugees. Like other black refugees, the Pandenarium settlers had no choice but to move. Historian Eric Durin had argued that "The ramifications of refusing a testamentary bequest of freedom were especially grave." 86 Refusing to take the freedom given from a testamentary bequest made the enslaved chattel part of the estate subject to liquidation. In Maryland, for instance, slaveholder John Parkham did not wait to die to manumit his enslaved blacks. He manumitted them and arranged for their relocation in Liberia. Shocked to find that his former bondspersons were not interested in living in Africa, Parkham contacted the county sheriff and requested his assistance in their removal. ${ }^{87}$

85 "Free Negroes," The Richmond Whig, (25 January 1853).

${ }^{86}$ Durin, 61.

${ }^{87}$ Ibid., 60. 
What set the settlers of Pandenarium apart from earlier black refugees in Pennsylvania was their access to resources. They did not leave Virginia with only the shirts on their backs. Charles Everett's estate guaranteed them some financial assistance. However, as the following chapter demonstrates, that access to assistance was not without pitfalls and hardships. The Pandenarium settlers lived the hardships of other refugees, attempting to adjust to life and homes different from those to which they were most accustomed. There remains a harsh irony to Henry Wise's paternalistic remarks towards colonization, "Africa gave to Virginia a savage and a slave; Virginia gives back to Africa a citizen and a Christian., ${ }^{, 8}$ Virginians took Africans and enslaved them, but when they found they could not hold them passively, they sought to return them to Africa or elsewhere.

${ }^{88}$ American Colonization Society, Fortieth Annual Report, 8. 


\section{CHAPTER 5}

\section{PANDENARIUM}

Arise and go to Paddan-aram ... God Almighty bless you and make you fruitful and multiply you, that you may become a company of peoples. May he give the blessing of Abraham to you and your descendents with you, that you may take possession of the land of your sojournings which God gave to Abraham. ${ }^{1}$

- Genesis 28: $2-3$.

In early November of 1854, fifty-two blacks boarded a train at Keswick Depot outside of Charlottesville, Virginia. ${ }^{2}$ Most of them had recently gained their freedom from bondage by a posthumous decree of manumission from Dr. Charles Everett. In any case, all fifty-two were heading north to Mercer County, Pennsylvania, to new homes and new futures. Their journey took them several days through three states and hundreds of miles. The time spent aboard the train afforded the black passengers time to reflect on their lives to that point as bondspeople, but it also gave them time to ponder the hope and possibilities of their futures as free persons of color. For all of the anxiety and hopefulness the journey offered, their departure was not necessarily of their own choosing and probably elicited some measure of sadness. For most of the black passengers, the Charlottesville area was the only home they had ever known. For some, departure also meant leaving behind loved ones, still in bondage. However, for the thirty-nine people recently manumitted from the Everett Estate, departure was a condition of their freedom. Like their predecessors in Mercer County, Pennsylvania, who sought

\footnotetext{
${ }^{1}$ Genesis $28: 2-3$ NRSV.

2 "Emancipated Slaves," The National Era, 7 December 1854 from The Promulgator, Mercer, PA. Albemarle County Will Book \#23, 327; Albemarle County Courthouse, Charlottesville, VA.
} 
refuge from the system of slavery, they arrived in the Keystone State as refugees, where they held hopes for a brighter future.

The earlier refugee settlement near Sandy Lake in Mercer County was populated by Blacks who escaped from bondage and either through their own efforts, assistance from the Underground Railroad, or a combination of both, made their way North. Their journeys from bondage to freedom differed markedly from the train ride taken by the refugees of 1854. Their movement from bondage to freedom was an acute movement with little or no planning at all. Many left with nothing more than the clothes on their backs. Often they left behind families and loved ones, knowing they might never see them again. This abruptness allowed them no time to ponder their futures; to do so might cost them their lives. Instead, their attentions were on the immediacy of their situations. Their bodies were commodities; as such, slaveholders and their agents pursued the refugees unwilling to relinquish the financial investments enslaved chattel offered in their labor. Frequently exhausted, hungry, and scared, those refugees who created the community known as Liberia arrived on the banks of Sandy Lake in rural Mercer County with a sense of relief.

For these Liberians the difficult choices they made and the resultant decisions to flee bondage often led to long, arduous, and perilous journeys. Unlike their Liberian predecessors, the Everett people did not have to look over their shoulders in fear. The Everett people arrived in Mercer at the end of a long journey, but their passage, first by train, then canal barge, and finally by wagon, was not fraught with the perils of an escape from bondage. Neither did they have to keep a low profile to avoid detection from slave catchers. Angry slaveholders anxious to recapture escaped chattel did not pursue the 
Everett people. On the contrary, they were anxious to see them go. Many Virginia slaveholders believed that they provided hope and inspiration for their enslaved brethren. This same hope and inspiration, slaveholders feared, could lead to revolts and insurrections aimed at destroying the system of chattel slavery. The mere presence of the former Everett bondspeople in Virginia then, made them enemies of slavery and by extension the state; as such, the system of chattel slavery dictated their departure from the state.

The lack of pursuit did not free the Everett people from the refugee experience. The same racism that rationalized their enslavement also sanctioned their exile from Virginia. William and Jane Pease noted in Black Utopia that, "The misery of servitude was but one impetus to flight. The pressure of discrimination was another."33 Other scholars like Melvin Patrick Ely have cautioned that it is erroneous to portray Southern states as a racist monolith. ${ }^{4}$ His study of the free black community of Israel Hill in Prince Edward County, Virginia, concluded that there was "considerable openness toward free African Americans in daily life." ${ }^{, 5}$ Local responses to emancipations and posthumous manumissions differed widely within Virginia. Indeed, the revised state codes gave counties the autonomy to decide how to deal with free blacks. The Everett people remained in Virginia for six years after the death of Dr. Charles Everett. Still, the legal and social structures were in place at the state level in Virginia to allow for the systematic oppression of blacks, both enslaved and free. Ely's premise is not incorrect, and it is

\footnotetext{
${ }^{3}$ William and Jane Pease, Black Utopia: Negro Communal Experiments in America, (Madison, Wisconsin: The State Historical Society of Wisconsin, 1963), p. 5.

${ }^{4}$ Melvin Patrick Ely, Israel on the Appomattox, (New York: Alfred A. Knopf, 2004), $144-174$.

${ }^{5}$ Ibid., 436.
} 
impossible to qualify every soul in the South as ardently racist, seeking to impede the progress of free Blacks. However, Ely fails to account for institutional racism, for institutional racism does not require the entire population of a state to share racist ideologies; only a few are required. In the Charlottesville area, the attitudes of the local whites leaned heavily toward the relocation of free blacks. Therefore, while the Everett people achieved freedom from bondage within the legal parameters of Virginia, the state nonetheless compelled them to leave or face re-enslavement.

Superficially then, the Everett refugees resemble voluntary migrants. They seemingly lacked any sense of urgency, remaining in Virginia for more than half a decade after the death of Charles Everett. Historians like Ely might even argue that had they not left Charlottesville, it is possible they would have settled into their new lives and in some cases thrived. Therefore, the decision of the Everett people to board the train at Keswick Depot gives the impression they did so of their own accord. While Ely's research demonstrates that free blacks could and did peacefully coexist with slaveholders in Virginia, his study of manumitted Blacks in Prince Edward County largely predates the legal obstacles facing the bondspersons of Charles Everett. ${ }^{6}$ At every turn, someone or something coerced the Everett people to leave the Commonwealth of Virginia. Although the choice to remain in Albemarle County existed for the former Everett bondspeople, doing so left them open to increased hardship. The slightest threat to the white patriarchy of Albemarle County, Virginia, could re-enslave them.

\footnotetext{
${ }^{6}$ Ely looked at the former bondspersons of Richard Randolph in Prince Edward County, Virginia. Like the Everett people they were posthumously manumitted, but the date of their manumissions in 1796 predates Virginia's legislative act forcing newly emancipated blacks to leave the state within a year of their emancipation. Melvin Patrick Ely, Israel on the Appomattox: A Southern Experiment in Black Freedom from the 1790s Through the Civil War, (New York: Alfred A. Knopf, 2004).
} 
The choice to stay, quite simply, placed them in a difficult situation. To that end, the Everett people anticipated hardships associated with the decision to stay. Additionally, they had incentives to leave. Dr. Everett's will established a fund for the purchase of land to relocate his former bondspeople outside of Virginia. It was far easier to acquiesce to their removal from Virginia. Certainly, the prospect of freedom, education, and land was not unappealing. Romantic visions did not draw the Everett people that boarded the train in November 1854 out of Virginia, however. At every turn whites in Albemarle County pushed them out of the state. ${ }^{7}$ The state legal codes and local authorities dictated that freedom for the Everett people depended upon their acceptance of exile from the state. The formerly enslaved Blacks, who boarded the train at Keswick, did so with great incentives to move to Pennsylvania; but more importantly, they left the threat of penalization behind them.

The cornerstone of the resettlement efforts in Mercer County was the purchase of land for the Everett people. Their acquisition of land set them apart from the earlier Black community of Liberia in Mercer County. Unlike the Liberians, the Everett refugees actually arrived in Mercer better off materially than had been their condition in Virginia. In 1854, they were free from the bonds of slavery with money in their pockets and heading to the Mercer County Courthouse to make their marks on deeds for land

\footnotetext{
${ }^{7}$ Sociologist Egon F. Kunz expanded upon the widely held push/pull theory of migration and refugee movement, arguing that further subtypes of acute refugee movement and anticipatory movement provided a better understanding of the refugee and the motivations behind their flight. Barry Stein later supported Kunz's work in his work defining the parameters of refugee studies. E.F. Kunz, "The Refugee in Flight: Kinetic Models and Forms of Displacement," International Migration Review, Vo. 7, No. 2 (Summer, 1973), 131 - 133. Barry N. Stein, "The Refugee Experience: Defining the Parameters of a Field Study," International Migration Review, Vol. 15, No. 1/2, Refugees Today. (Spring - Summer, 1981), $321-323$.
} 
upon which they could farm or establish businesses to provide them with the material goods, which were, in some cases, previously unattainable. With such possibilities awaiting them, it is not hard to imagine the degree of their optimism. Rose Allen, probably spoke for many of her fellow Everett refugees in the days immediately following their arrival when she declared her new home in Mercer County was "just like heaven." 8

In contrast, the Liberians, in time, built farms and fared reasonably well in their agrarian efforts, but the land they farmed belonged to Richard Travis. ${ }^{9}$ As refugees pursued by slaveholders and their agents, the Liberians could not afford to leave legal records of their settlement in Mercer County. Consequently, few Liberians actually held legal title to the lands upon which they lived. That kind of paper trail made their recapture almost a guarantee. They depended upon secrecy and part of that secrecy meant they could not draw attention to themselves by transferring property in the courts.

It is doubtful that either the Everett refugees or the earlier Liberians planned to settle in Mercer County. Many of the Liberians had no plans beyond escaping bondage; they did not necessarily pinpoint Mercer County, Pennsylvania, as their ultimate destination. They settled only after they found assistance and refuge, which is reflective of their dramatic and cumbersome movements to escape bondage. However, the decision of where to settle was one condition over which Liberians had more control than the later Everett refugees. Once in Pennsylvania, the Liberians held a greater degree of selfdetermination over their lives and their homes. Even though they could not risk holding

\footnotetext{
${ }^{8}$ Hubert Rex Johnson, A History of the Neshannock Presbyterian Church, (Washington, D.C.: National Capital Presbytery Inc., 1925), 231.

${ }^{9}$ Mercer County Deed Book E1, 412 - 413 and Mercer County Deed Book P1, 326 327, County of Mercer Recorders Office; Mercer, Pennsylvania.
} 
legal title to the lands in Mercer, they could decide to remain or to continue their journey to another location with more favorable conditions. The Everett people on the other hand, had no say in their relocation to Mercer; the paternalism of Dr. Everett and subsequently his agents made that decision for them.

Rose Allen's comparison to heaven set the expectations high for the new refugees in Mercer County, perhaps too high. They were no longer enslaved and they did enjoy the privileges of free persons of color. However, they were still persons of color and that influenced just how much they could enjoy their freedom and defined just what freedom meant under the law. Their much-cherished freedom was probably very different from what they had envisioned in the years preceding their departure from the Everett plantation. Freedom, as Eric Foner has explained, has different meanings to different people at different times in American history. ${ }^{10}$ The courts awarded the Everett people their "freedom" only if they remained dependent upon white patriarchy. At every step of the resettlement process, the legal codes reinforced the paternalism of nineteenth century American society, both North and South. The Everett refugees probably harbored some romantic and unrealistic expectations, but many of those expectations were only unreasonable because of the social hierarchy of a paternalistic American society. ${ }^{11}$

Dr. Charles Everett's posthumous manumission of his enslaved chattel was not without conditions. His will gives clear indication that manumission and relocation were

${ }^{10}$ Eric Foner, The Story of American Freedom, (New York: W.W. Norton and Company, 1998), xiii - xxii.

${ }^{11}$ Stein notes that this is often the case in refugee resettlement efforts, "refugees' expectations, [are] often romantic and unrealistic, which are quite different from what we know they should expect." He further notes that these expectations help shape the refugees' behavior during the resettlement period. Barry N. Stein, "The Refugee Experience: Defining the Parameters of a Field of Study," International Migration Review, Vol. 15, No. 1/2, Refugees Today. (Spring - Summer, 1981), 325. 
inseparable; there could not be one without the other. Dr. Everett amended his will just days before his passing, granting his nephew the authority to make the decision as to where to relocate his former chattel. ${ }^{12}$ In doing so, he left open the possibility that Charles Everett, Jr. might find it more prudent and more profitable to spare the expense of relocation and allow the Everett people to remain in the Charlottesville area. Unlike his uncle, the younger Everett was not active in Virginia politics, nor had he ever been. Until that moment, the younger Everett was not a slave owner himself. His family in Kentucky was not nearly as financially as secure as his uncle in Virginia. Consequently, although aware of slavery, it is probable that Everett, Jr. first experienced the management of enslaved chattel after his uncle's passing.

Charles Everett, Jr. left no record of the thoughts which motivated his thinking and ultimate decision to relocate his uncle's former chattel to Pennsylvania. But, neither had Charles Everett, Sr. given any indication as to why he amended his will to allow his executor to relocate them wherever he saw fit. Perhaps the two Everetts spoke confidentially before the elder Everett's passing. In any case, both men were of the same mind that the Everett people could not stay in Virginia. Charles Everett, Jr. concluded the best option was to relocate his uncle's former bondspersons outside of Virginia.

The younger Everett's decision to relocate his uncle's former bondspeople outside of Virginia was not without obstacles. Perplexed by the task of carrying out his uncle's wishes the younger Everett appealed to the courts for guidance. The local courts advised Charles Everett, Jr. not to pay any money to the Everett people until they left the state of

${ }^{12}$ Last Will and Testament of Dr. Charles Everett, Albemarle County Will Book \#2, 107 - 108; Albemarle County Courthouse, Charlottesville, VA. 
Virginia. ${ }^{13}$ Such advice exerted additional pressures on the Everett people to leave Virginia, but did not necessarily satisfy Charles Everett's queries how to relocate his uncle's former bondspeople. As to the land acquisitions, specifically how to title the lands, the courts advised Everett that,

As a general rule the conveyance should be to the party by who it is purchased - when from the profligate habits of the negro the property would be likely to be wasted - most assuredly. ${ }^{14}$

In all cases, Everett held title of the lands in trust for the Everett refugees.

Holding the land in trust acknowledged the advice of the Virginia chancery courts that Blacks were prone to "profligate habits." However, the trusteeships were also designed to thwart the efforts of others looking to take the lands, by fair means or foul, from the Everett refugees. The new deeds stipulated the conditions,

In trust however that whilst the legal title shall be held by the said Charles D. Everett yet he shall permit the persons ... who were emancipated by the last will and testament of Chas. Everett late of Albemarle County Virginia to occupy the same and enjoy the rents issues and profits thereof ... but the same shall be regarded as a trust subject to be managed and controlled by the court aforesaid through the said Chas. D. Everett aforesaid or in a such other way as the court shall direct. ${ }^{15}$

Although the Everett refugees were free to occupy and use the lands, they were unable to hold outright legal claim to them. Neither could they sell or convey the lands unless they did so posthumously through their respective estates. ${ }^{16}$ As long as Charles Everett held the lands in trust for the refugees, they were not free to convey their lands for profit. The

${ }^{13}$ Albemarle County Chancery Orders \#3, (1849 - 1854), 455 - 456; Albemarle County Courthouse, Charlottesville, VA.

${ }^{14}$ Albemarle Chancery Court Orders \#3, (1849 - 1854), 456; Albemarle County Courthouse, Charlottesville, VA.

${ }^{15}$ Mercer County Deed Book D2, 424; Mercer County Recorders Office, Mercer County Courthouse, Mercer, PA.

${ }^{16}$ Mercer County Deed Book D2, 428 - 454; Mercer County Recorders Office, Mercer County Courthouse, Mercer, PA. 
trust tied them to the lands. They could move from Mercer County but by doing so they left without land and ultimately in a more precarious financial state. Even with assurances of financial support in return for their departure, the dependencies created by the trusts gave the Everett people reason to be anxious of uncertainties ahead of them.

As much as the trusteeships signaled a continuance of white paternalism, so too did the guardianships established by the estate. Virginia's chancery courts ordered that all of the children of the Everett people have legal guardians in Pennsylvania. The parents, themselves, were ineligible because even in Pennsylvania they were not full citizens. ${ }^{17}$ The estate allowed that parents could receive enough money from the children's portion of the inheritance to provide for their maintenance. Any other monetary requests could only come from the court-appointed guardians. ${ }^{18}$ The establishment of these guardianships verified the Chancery Court's belief that free blacks, and specifically those freed by the Everett estate, could not avoid capricious and wasteful spending of their inheritance. The Everett refugees depended upon the judgments of prominent white men in Mercer County to decide the best interests of their children.

Of the court appointed guardians, William F. Clarke and William Stephenson were perhaps best known. ${ }^{19}$ William F. Clarke had assisted Charles Everett, Jr. in securing land in Mercer County, and was already familiar, at least in name, with the

\footnotetext{
${ }^{17}$ Mercer County Deedbook D2, 159 - 160, 166 - 167, and 421 - 428; Mercer County Courthouse, Mercer, PA. Albemarle County Chancery Orders \#3, (1849 - 1854), 455 456; Albemarle County Courthouse, Charlottesville, VA.

${ }^{18}$ Albemarle County Chancery Orders \#3, (1849 - 1854), 455 - 456; Albemarle County Courthouse, Charlottesville, VA.

${ }^{19}$ Although prominent, Clarke and Stephenson were not the only court appointed guardians. The courts also appointed Samuel Griffith and Henry Pearson as guardians. Albemarle Chancery Court Orders \#5, (1857 - 1860), 230 - 234; Albemarle County Courthouse, Charlottesville, VA.
} 
Everett refugees when they arrived in late 1854. Clarke was a well-known newspaper editor in Mercer, who dabbled in the fledgling oil business in northwestern Pennsylvania. ${ }^{20}$ His peer, William Stephenson, was a well-respected jurist and lifelong resident of Mercer County. Stephenson was also instrumental in bringing a Water Cure Institution to Mercer, under the direction of Dr. James Catlin, physician from a prominent abolitionist family in nearby Warren County. ${ }^{21}$

Although the guardianships limited the financial abilities of refugee parents, they did not reduce them to surrogates. They remained active in their children's lives on a day-to-day basis. Many parents used the funds available to support the education of their children, a luxury they themselves never enjoyed. ${ }^{22}$ Not only did the guardianships not strip refugees of their parental roles, some families took in other children from the community. Emma Stick lived with Ed and Judy Watson in 1860, and the Watsons ensured that the young girl attended school. Likewise, the Reeves family took in the eleven year old John Gallon and made sure that he too attended school regularly. ${ }^{23}$ The Watsons and Reeves received no additional funding from the Everett estate for taking in Emma Stick and John Gallon, and it is not clear if Mercer County officials compensated

\footnotetext{
20 "Diary of William F. Clark, Jr." 18 January 1862, Historical Society of Western Pennsylvania; Pittsburgh, PA.

${ }^{21}$ Letter from James Catlin to Frederick Douglass in the Frederick Douglass Paper, 3 June 1853.

${ }^{22}$ The 1860 Census reveals that the families with children of school age, almost without exception, sent their children to nearby schools. Schedule 1 - Free Inhabitants of East Lackawannock in the County of Mercer, State of Pennsylvania, Census Series M653, Roll 1139, 203 - 204, and Schedule 1 - Free Inhabitants of Mercer in the County of Mercer, State of Pennsylvania, Census Series M653, Roll 1139, 243 - 244; Schedule 1 Free Inhabitants of Springfield Township in the County of Mercer, State of Pennsylvania, Census Series M653, Roll 1140, 78 - 79.

${ }^{23}$ Schedule 1 - Free Inhabitants of East Lackawannock in the County of Mercer, State of Pennsylvania, Census Series M653, Roll 1139, 203 - 204.
} 
them for their generosity. If they received no funding from officials, either locally or at the state level, these families indeed extended themselves to support not only their children but also other Black children in Mercer County.

Despite the parenting skills and philanthropy demonstrated by the Everett refugees, the guardianships still held a great deal of legal and financial significance. Refugee women found themselves doubly impacted by patriarchy. At home, they were subject to their husbands' wishes and demands, but in the eyes of the courts they were subject to the demands of the estate trusts, and legal guardianships of a legal system controlled by white men. For refugee men, the legal system made them heads of households in name only. Ultimately, financial decisions regarding their children fell to white male guardians. The guardianships forced refugee parents to choose between staying in Mercer County and receiving the continued support of the Everett estate or leaving and exclusively supporting their children by their owns means. If they left, certainly they assumed the financial responsibilities denied them under the guardianships. That was, however, a double-edged sword because that responsibility did not give them equal access to the courts. Put simply, if they stayed they were subject to the whims of white patriarchy but had access to financial assistance; if they left they were subject to the whims of white patriarchy without financial assistance. Consequently, none of the refugee parents opted to leave; the risk of living outside of Mercer County outweighed the reward.

The Everett refugees faced other restrictions to their movements aside from their land trusts and guardianships. The Fugitive Slave Law of 1850, which drove the earlier Liberian community from Mercer County, helped restrict the movements of the later 
Everett refugees. Although freed by Dr. Charles Everett's will, the continued liberty of the refugees was as much at risk as their Liberian predecessors. The Fugitive Slave Law, later affirmed by Scott v. Sanford (1857), assumed that all blacks were slaves first and free persons of color second. In explaining his decision in the Scott case, Chief Justice Roger Taney concluded that,

It is difficult at this day to realize the state of public opinion in relation to that unfortunate race which prevailed in the civilized and enlightened portions of the world at the time of the Declaration of Independence and when the Constitution of the United States was framed and adopted. But the public history of every European nation displays it in a manner too plain to be mistaken. They had for more than a century before been regarded as beings of an inferior order, and altogether unfit to associate with the white race either in social or political relations, and so far inferior that they had no rights which the white man was bound to respect, and that the negro might justly and lawfully be reduced to slavery for his benefit. $^{24}$

Taney's language made it clear that whether enslaved or free; blacks anywhere in the United States lived each day in uncertainty. Lawmakers in Harrisburg understood the dangers free black Pennsylvanians faced and took modest measures to ensure their safety. For the Everett refugees, protection came in the form of legislation, which identified them as "legitimate" free persons of color. ${ }^{25}$ This protection offered little comfort if they chose to leave Mercer County however. The laws, which affirmed the liberty of the refugees, conspired to confine their movements to Mercer County. Faced with the frightening prospect of capture and sale by slave-catchers, the Everett refugees chose to

${ }^{24}$ Scott v. Sanford, 60 US (19 Howard) 407 (1857).

${ }^{25}$ An Act to Authorize and Empower the Court of Common Pleas of Mercer County to Legitimate Certain Persons who were Emancipated by the Last Will and Testament of Dr. C.D. Everett, late of Albemarle County, Virginia. Laws of the General Assembly of the state of Pennsylvania, No. 324. 
stay in their new homes. For good or for ill, refuge from slavery meant that the Everett refugees had to bind their collective fates to Mercer County.

Resettlement efforts in other states also faced obstacles similar to those faced by the Everett refugees; their circumstances were not entirely unique. The experiences of these earlier resettlement efforts helped to shape the planning behind the relocation of the Everett people. ${ }^{26}$ About the time that Dr. Charles Everett passed away, black refugees from the estate of John Randolph found themselves face to face with angry mobs in southern Ohio. Like Everett, John Randolph emancipated his bondspeople posthumously, and looked to have them resettled outside of Virginia. By strange coincidence, Randolph's executor secured land for the newly emancipated blacks in Mercer County, Ohio. The executor selected this area because it was home to an already growing black community built around the Emlen Institute. In the first quarter of the $19^{\text {th }}$ century, Augustus Wattles established the Institute as a school for agricultural and mechanical training for black children. The relative success of this small, but growing black community, coupled with the arrival of nearly three hundred blacks freed by the Randolph Estate, was too much for neighboring whites to absorb. The arrival of the Randolph people drew the ire of the neighboring white community. When they arrived by boat in southern Mercer County, Ohio, angry white mobs met them at the docks. The

\footnotetext{
${ }^{26}$ Two works provide a particularly good synopsis of black resettlement efforts in the antebellum United States. "Transplanting Free Negroes to Ohio from 1815 to 1858," by Powell, Kavanaugh, and Christy gives a chronology of black resettlement efforts in Ohio; while Black Utopia, by William and Jane Pease takes a more critical look at these settlements on a broader scale, encompassing Canada as well as the United States. C. A. Powell; B.T. Kavanaugh; David Christy, "Transplanting Free Negroes to Ohio from 1815 to 1858," The Journal of Negro History, Vol. 1, No. 3, (June, 1916), 303. William H. Pease and Jane Pease, Black Utopia: Negro Communal Experiments in America, (Madison: The State Historical Society of Wisconsin, 1963).
} 
whites advised them not to disembark and to keep going, anywhere but Mercer County, Ohio. By 1857, even the once promising Emlen Institute gave in to the racial tensions in southern Ohio and moved to Bucks County, Pennsylvania. ${ }^{27}$

There were other settlement efforts that did not face the racial hostilities of the Randolph people, and yet, even for black refugees not driven out by neighboring whites, uncertainties still loomed. In an earlier resettlement effort in Ohio, the former bondspersons of Samuel Gist arrived by way of Virginia in 1818. Within a short time the Gist settlements prompted one observer to declare that, "Their situation, unfortunately, is not prosperous. ${ }^{, 28}$ Editorials in the Cincinnati Gazette and Alexandria Gazette, were equally ominous in their descriptions of the settlements when they rhetorically asked, "In all Ohio can any white settlement be found equally wretched, equally unproductive?"29 These unfavorable descriptions belie the fact that the emancipated black refugees who populated these settlements acquired their lands in the same manner as the Everett refugees. Their former slaveholder, Samuel Gist, provided funds in his estate to resettle his former chattel in Ohio. Even with land and the financial resources of the Gist estate, clearly the black refugees struggled. ${ }^{30}$ Whether the Everett people heard of the fates of

${ }^{27}$ Henry Noble Sherwood, "The Settlement of the John Randolph Slaves in Ohio," Proceedings From the Mississippi Valley Historical Association, (Mississippi Valley Historical Society, 1912), 42. Frank F. Mathias, "John Randolph's Freedmen: The Thwarting of a Will," The Journal of Southern History, Vol. 39, No. 2 (May, 1973), 266 -267 , and 270 .

${ }^{28} \mathrm{H}$. Howe as quoted in William Buckner McGroarty, "Exploration in Mass Emancipation," William and Mary Quarterly Historical Magazine, $2^{\text {nd }}$ Ser., Vol. 21, No. 3, (July, 1941), 218.

${ }^{29}$ The editorial appeared in the Alexandria Gazette, 1 December 1835, but was taken from an earlier undated editorial in the Cincinnati Gazette.

${ }^{30}$ William Buckner McGroarty, "Exploration in Mass Emancipation," William and Mary Quarterly Historical Magazine, $2^{\text {nd }}$ Ser., Vol. 21, No. 3, (July, 1941), 217 - 218, and 225 - 226. C. A. Powell; B.T. Kavanaugh; David Christy, "Transplanting Free Negroes to 
the attempted Randolph and Gist settlements is unknown, but it does point to the degree of uncertainty ahead of them. There was no guarantee of success in their move north to Pennsylvania; they had no idea if their White neighbors would accept them or greet them with hostility and angry mobs.

As reassuring and warm as the reception may have been, there were, however, other reasons for the Everett people to remain concerned and uncertain of what lay ahead. Their arrival in the Mercer County Courthouse signaled new limitations in their lives. Although theirs was a well-planned and organized move, with pre-purchased lands and a good deal of financial support from the Everett estate, in some ways they were no better off than the earlier black refugees in Mercer County. Local historians like to recount that the Everett refugees arrived in Mercer to find houses, clothing, schools, and a church constructed for them, but this is more legend than fact. ${ }^{31}$ The legend probably results from two considerations: the Chancery Court of Albemarle County, Virginia, allowed that Charles Everett, Jr. could, if he wished, provide housing for the refugees; and secondly, Everett did arrange for the purchase of an existing house in the borough of Mercer for one refugee, Joe Duke. ${ }^{32}$ The preplanning of the resettlement of the former Everett bondspersons in Mercer did not include the advanced construction of any village or town. The Everett refugees had to secure for themselves the necessities of food and

Ohio from 1815 to 1858," The Journal of Negro History, Vol. 1, No. 3, (June, 1916), 303.

${ }^{31}$ Christina Greggs, "Pandenarium was a dream that turned into a nightmare," The Sharon Herald, 28 February 2000; Gail Habbyshaw, "Follow the Drinking Gourd: Walking Tour of Mercer's Historic Underground Railroad and Abolitionist Era Sites," Mercer County Historical Booklets, MCHS Booklet \#2 (Mercer, PA: Mercer County Historical Society, 2002), 17; Larissa Theodore, "PBS Documentary tells local Underground Railroad story,” The Sharon Herald, 20 February 2003.

${ }^{32}$ Mercer County Deed Book D2, 441 - 443; Mercer County Courthouse, Mercer, PA. 
shelter. Even then, with simple necessities secured they still needed to assure that they could maintain subsistence in their new homes.

The local stories of newly constructed houses with crates of clothing awaiting the Everett refugees stand in stark contrast to the more recent recollections that the resettlement effort was a failure. ${ }^{33}$ According to popular accounts and local historians, disease and misery beset the Everett refugees. In 2000, one local newspaper retold the history of the Everett refugees and their settlement in Mercer. Entitled, "Pandenarium was a Dream that turned into a Nightmare" the theme of the article was not left to the imagination. ${ }^{34}$ The inevitable consequence of these stories is that either the refugees themselves failed to cultivate the generous resources availed them by the Everett estate to create a thriving black community in Mercer County or that they were personally ill equipped for the rigors of life outside of Virginia. Within two years of their arrival in Mercer, as the popular history recalls, the Everett refugees completely abandoned Mercer County.

As memories faded, fact and fiction ran together to retell the story of the little studied resettlement of the Everett refugees. The initial histories of the Everett refugees describe an effort to elevate formerly enslaved blacks to productive and valuable

${ }^{33}$ Recent accounts by local historians claim that the Everett refugees suffered from an epidemic of Tuberculosis which nearly wiped out their settlement. In the aftermath of the epidemic the remaining refugees either moved into the borough of Mercer or abandoned the resettlement efforts entirely by returning to the South. Christina Greggs, "Pandenarium was a dream that turned into a nightmare," The Sharon Herald, 28 February 2000; Gail Habbyshaw, "Follow the Drinking Gourd: Walking Tour of Mercer's Historic Underground Railroad and Abolitionist Era Sites," Mercer County Historical Booklets, MCHS Booklet \#2 (Mercer, PA: Mercer County Historical Society, 2002), 17; Larissa Theodore, "PBS Documentary tells local Underground Railroad story," The Sharon Herald, 20 February 2003.

${ }^{34}$ Christina Greggs, "Pandenarium was a dream that turned into a nightmare," The Sharon Herald, 28 February 2000. 
members of the broader community. The Reverend Hubert Rex Johnson first described the "Colony of Liberated Slaves," in his book on the Neshannock Presbyterian Church. Johnson's description was the first to provide a name for the Everett refugees' settlement - Pandenarium. ${ }^{35}$ It should come as no surprise then, considering Johnson's occupation as a minister, that the village took a name with biblical connotations. Pandenarium, as previously noted, probably derived its name from the story of a biblical refugee, Jacob. ${ }^{36}$ Seeking to escape the wrath of his angry brother, Jacob fled his homeland and sought refuge in the land of his mother's family, Paddan-aram. Like Jacob, the new black settlers in Mercer County hoped to become fruitful and multiply. ${ }^{37}$

There is no indication that the Everett refugees ever referred to their new home as Pandenarium. This is in part because they did not settle together in one location in Mercer County. Unlike the earlier Liberian settlement in Mercer County, the arrangements made by Charles Everett dispersed the Everett refugees throughout the county. None of the lands purchased by Everett and his agents formed a village, or municipality. In short there never was a village called Pandenarium. Instead, Everett and his agent purchased land in several different townships and dispersed the Pandenarians accordingly. The broad dispersal of the former Everett bondspeople also denied the existence of an area within the county exclusively settled by the new refugees. Early county histories fail to mention any black community called Pandenarium in Mercer

\footnotetext{
${ }^{35}$ Hubert Rex Johnson, A History of the Neshannock Presbyterian Church, (Washington, D.C.: National Capital Presbytery Inc., 1925), 229 - 232.

${ }^{36}$ W. Edward Weidhmann, "Indian Run History Compiled By Educator," The New Wilmington Globe, 23 August 1973. Hubert Rex Johnson, A History of the Neshannock Presbyterian Church, (Washington, D.C.: National Capital Presbytery Inc., 1925), 231. ${ }^{37}$ Genesis 28: 2 - 3 .
} 
County, but they do mention the presence of Black families in the area of Indian Run. ${ }^{38}$ As late as 1908, the obituary of Rose Allen recorded that she came to Pennsylvania a few years before the Civil War and "settled at Indian Run."39 Therefore, when Johnson first described Pandenarium in 1925, he created a black village, which previously never existed. Reverend Johnson's efforts certainly attempted to paint a triumphant vision of the Everett refugees, and compare them favorably with the biblical refugee, Jacob. ${ }^{40}$

Subsequent accounts of the Everett refugees built upon Johnson's work. By 1925, a Mercer Dispatch and Republican article reminded readers of the "Freed Slaves at Indian Run." "A1 “A wealthy southerner," according to that account, started the colony because his "conscience came to bother him when he came to die."42 The author of the article remembered that Nancy Bell, a sister of Rose Allen, came to Mercer often to trade. "She was a cheerful old soul," who "had 20 children, one every year for a while." articles reinforce the impression of a "colony" or settlement, but neither recall the name Pandenarium or paint a dismal picture of the Everett refugees' experience. However, by the end of the twentieth century, Pandenarium was no longer a colony of "cheerful old souls." Pandenarium became a place of anguish and suffering, despite the best intentions and efforts of the doctors Everett.

Citing an earlier work by Mary Jayn Woge, a Sharon Herald writer, Christina Greggs explained that the Everett refugees,

${ }^{38}$ History of Mercer County (Chicago: Brown, Runk and Company, Publishers, 1888), $203-205$.

39 "Recent Deaths," The Mercer Dispatch, 13 March 1908.

${ }^{40}$ Hubert Rex Johnson, A History of the Neshannock Presbyterian Church, (Washington, D.C.: National Capital Presbytery Inc., 1925), 229 - 232.

${ }^{41}$ Remembrances," Mercer Dispatch and Republican, 13 June 1930.

${ }^{42}$ Ibid.

43 Ibid. 
arrived wearing muslin clothes and shoes, something only masters and their families enjoyed. The new residents found 24 two-story homes complete with furniture, household necessities and crop seeds. ${ }^{44}$

The colony quickly soured because the Southerners were not used to the harsh winters of Mercer County. The cold and the Everett refugees' lack of preparedness led to disease. What started as pneumonia became tuberculosis in subsequent tellings, and illness nearly wiped out Pandenarium. Complicating matters, when offered medical treatment by the local community, the Everett refugees refused. Even their financial support crumbled because the Everett refugees "were not used to handling money, and many fell prey to white swindlers." ${ }^{45}$ Within two years, the colony disbanded and some families even surrendered themselves back into slavery. ${ }^{46}$ Subsequent stories and articles repeated these claims of the nightmare that overwhelmed Pandenarium offering little detail, and frequently repeating the claims almost word for word. ${ }^{47}$

These various recountings of the fate of Pandenarium provide no evidence for their claims. Certainly, the winter weather may have been harsher than what the Everett refugees had previously experienced, but the Everett refugees were probably equipped to handle the conditions. After all, they did not arrive in Mercer County until November of

\footnotetext{
${ }^{44}$ Christina Greggs, "Pandenarium was a dream that turned into a nightmare," The Sharon Herald, 28 February 2000.

${ }^{45}$ Ibid.

${ }^{46}$ Ibid.

${ }^{47}$ Gail Habbyshaw, "Follow the Drinking Gourd: Walking Tour of Mercer's Historic Underground Railroad and Abolitionist Era Sites," Mercer County Historical Booklets, MCHS Booklet \#2 (Mercer, PA: Mercer County Historical Society, 2002), 17; Larissa Theodore, "PBS Documentary tells local Underground Railroad story," The Sharon Herald, 20 February 2003; and Lillian Reeher, "Anti-Slavery at Indian Run Began at Neshannock Church," Wolf Creek Legacy II, 69, Mercer County Historical Society; Mercer, Pennsylvania; and Roland Barksdale Hall, "People in Search of Opportunity: The African American Experience in Mercer County, Pennsylvania, A History and Guide," Penn State University: Shenango Valley Campus.
} 
1854; they had already provided for themselves for six years. The more recent accounts of the Everett refugees' experience appear to conflate their story with those of two other Black refugee settlements in Ohio, the Gist and Randolph settlements.

With winter closing in on Mercer County in early November 1854, the first task for the Everett refugees was the construction of housing. Having arrived so late in the year, staying warm and dry was a priority not simply for comfort but for survival. The winter snows brought cold and moisture, which in turn brought a greater probability for disease and exposure. If that first winter was anything like that of 1855 , "the ensuing winter was cold, and supplied with deep snow." ${ }^{48}$ Without housing, any settlement of the Everett refugees would have more closely resembled the Gist settlements in Ohio. Decades before and a state away in Ohio, observers openly referred to the early Gist settlements not as communities or even settlements, but as camps. ${ }^{49}$ The camp-like accommodations might not have been wholly uncomfortable in the short term, but, the longer the conditions remained camp-like, the less likely they were to feel safe and comfortable in their new homes. During the winter months, camps would have promoted disease and in some cases exposure. The Gist refugees in Ohio found themselves largely without financial assistance, and few local contacts to help them resettle. ${ }^{50}$

\footnotetext{
${ }^{48}$ History of Mercer County, Pennsylvania. Its Past and Present, (Chicago: Brown, Runk and Co., Publishers, 1888), 335.

${ }^{49}$ Historian William McGroarty referenced two early Ohio resettlement efforts one near Georgetown, and the second in Eagle Township. In both cases he referred to them not as villages, towns or even settlements, but as "camps." His descriptor was apparently taken from an editorial in the Alexandria Gazette (7 December 1835), wherein the author discussed the "emancipated negroes [of] the Brown County camps." William Buckner McGroarty, "Exploration in Mass Emancipation," William and Mary Quarterly Historical Magazine, $2^{\text {nd }}$ Ser., Vol. 21, No. 3, (July, 1941), 218, 225, and 226.

${ }^{50}$ William and Jane Pease, Black Utopia: Negro Communal Settlements in America, (Madison, Wisconsin: The State Historical Society of Wisconsin, 1963), p. $24-25$.
} 
Consequently, the Gist refugees struggled to establish themselves and their communities suffered accordingly.

What the Gist camps lacked in Ohio, the Everett refugees enjoyed in Pennsylvania. Local whites, in Mercer County assisted the Everett refugees, prompting them to remember years later that their new neighbors "received us so kindly, and the joy of freedom seemed so wonderful. ${ }^{, 51}$ Even with assistance, new houses did not appear overnight; the construction of houses for over fifty black refugees took time. Within the first few days of their arrival, the black refugees' new homes probably resembled a more camp-like atmosphere. What specifically local whites donated in time, money, labor, construction materials, or a combination thereof is unclear. What is clear is that assistance did not cease after initial settlement; some local whites served as guardians for the children and in some cases local trustees who worked on behalf of Charles Everett, Jr. in executing the conditions of his uncle's estate. ${ }^{52}$

Despite the warmth of the initial reception and the dispersal of their farms, not everyone in Mercer was happy to see the arrival of black refugees from Virginia. Some local whites in Mercer viewed the new arrivals with suspicion and threatened to hold white abolitionists responsible for any increase in criminal activity in the county. ${ }^{53}$ Resistance to the relocation of black refugees in or around white communities was not unusual, as evidenced by the cold reception the Randolph refugees experienced in Ohio.

\footnotetext{
${ }^{51}$ Hubert Rex Johnson, A History of the Neshannock Presbyterian Church, (Washington, D.C.: National Capital Presbytery Inc., 1925), 231.

${ }^{52}$ Mercer County Deedbook D2, $159-160,166-167$, and $421-428$; Mercer County Courthouse, Mercer, PA. Albemarle County Chancery Orders \#3, (1849 - 1854), 455 456; Albemarle County Courthouse, Charlottesville, VA.

${ }^{53}$ Hubert Rex Johnson, A History of the Neshannock Presbyterian Church, (Washington, D.C.: National Capital Presbytery Inc., 1925), 231. W. Edward Weidhmann, "Indian Run History Compiled By Educator," The New Wilmington Globe, 23 August 1973.
} 
In Mercer County, Ohio, the Randolph refugees attempted to settle in alongside newly arrived immigrants from German principalities in Europe. While it is hard to conceive that neighboring whites might be envious of black refugees, the Randolph people arrived at their destinations with the promise of land already purchased on their behalf and some measure of financial support from the respective estates. Not all of their white neighbors enjoyed these privileges. The newly arrived German immigrants did not benefit from the same philanthropy that supported the Randolph refugees; the immigrants from Europe, often had little money, and even less land..$^{54}$

The source of tensions between the Everett refugees and their white neighbors did not result from feelings of competition or envy. In Mercer, Pennsylvania misconceived notions of race and prevailing racial stereotypes led some whites to view the newly arrived black refugees in a dim light. Whites in Mercer County subjected the Everett refugees, who arrived in better circumstances than most, to the abuses and ridicule resulting from stereotypes of the day. Mercer County whites, however, were not alone in their treatment of black refugees. By 1863 , the Pennsylvania state legislature entertained debate of a bill to prevent further black immigration into the state. The Harrisburg Patriot reported that, "Its provisions [were] few and simple, and [met] the views of a large majority of the people in Pennsylvania." ${ }^{, 55}$ While the bill never became law, it did not prevent further stereotyping nor did it eradicate existing animosities directed towards blacks entering the state.

\footnotetext{
${ }^{54}$ Frank F. Mathias, "John Randolph's Freedmen: The Thwarting of a Will," The Journal of Southern History, Vol. 39, No. 2 (May, 1973), 267.

${ }^{55}$ Erie Observer, 11 April 1863 from the Harrisburg Patriot.
} 
Whether Everett refugees were predisposed to thievery or not, some white neighbors cast suspicious eyes in their direction, looking to ascribe guilt upon them. Though perhaps not intentionally, some gave credence to fears that some whites had of inherent Black criminality. Within three years, a few Everett refugees found themselves facing criminal indictments. In 1856, the courts indicted Samuel Bell for Malicious Mischief and required Bell to swear a Surety of the Peace. ${ }^{56}$ Samuel Bell's actual crime, for which a Grand Jury indicted on charges of malicious mischief, was stealing one of his neighbor's sheep and killing it - presumably to eat. Bell's case never went to trial. $\mathrm{He}$ swore a Surety of Peace and agreed repay his neighbor the value of the sheep, and pay for court costs. All told, the affair cost Samuel Bell $\$ 3.50 .{ }^{57}$ Two years later Windsor Duke found himself before the court to answer charges that he "obtain[ed] goods by means of false pretenses.. ${ }^{, 58}$ The following year in 1859, Samuel Bell was back before the court answering to new charges. This time authorities charged Bell with "furnishing liquor to minors and to persons of known intemperate habits. ${ }^{, 59}$ The subsequent rulings by the local court in the cases of Windsor Duke and Samuel Bell are unclear; the corresponding records have been lost.

Bell and Duke were not the only refugees to face charges. Between 1863 and 1873, two of "Aunt" Rose Allen's children faced charges. Authorities charged her son John with larceny for stealing banknotes from Edward Wasser. John Allen pleaded guilty

\footnotetext{
56 “April Sessions, 1856," Mercer County Quarter Sessions Docket (April 1856 - April 1868) Book 6, pp 8-9; Mercer County Clerk of Courts Office, Mercer, PA.

${ }^{57}$ Commonwealth v. Samuel Bell, No. 16 of April Sessions 1856, "Indictment: Malicious Mischief;" Mercer County Prothonotary Office, Mercer, PA.

58 "August Sessions, 1858," Mercer County Quarter Sessions Docket (April 1856 - April 1868) Book 6, pp. 187; Mercer County Clerk of Courts Office, Mercer, PA. 59 "August Sessions, 1859," Mercer County Quarter Sessions Docket (April 1856 - April 1868) Book 6, pp. 276.
} 
to the charge of larceny and, because he was a minor, the court sentenced him to the House of Refuge of Western Pennsylvania in Allegheny County. John may have felt compelled to plead guilty because the prosecutor in the case was the same man from whom he stole the banknotes. The Mercer County court records make no mention of the length of sentence, merely noting that the Mercer County Sheriff transported the young Allen to the House of Refuge. ${ }^{60}$ Seven years later, in 1870, another Allen child was in court. Aunt Rose's daughter, Ann, stood before the court to answer charges of

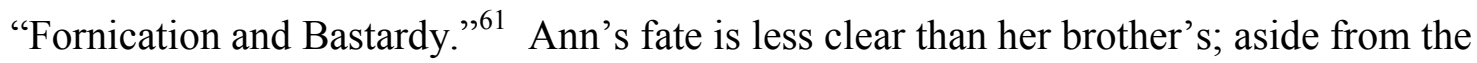
recorded indictment in the Mercer County Quarter Sessions Docket, no additional records exist to reveal the specifics of her case or the outcome.

Three other Everett refugees ran afoul of the law. In 1867, a grand jury indicted spouses Ed and Judy Watson for "Assault and Battery."62 Just a year earlier, George Duke faced charges that he "Sold Liquor without a license; Sold liquor on a Sunday; Sold liquor to a minor; and Sold liquor to persons of known intemperate habits."63 With the exception of the Watsons, the crimes for which the Everett refugees stood accused were all non-violent. Although only a small portion of the refugees found themselves indicted by the local courts, these few undoubtedly affirmed the fears of some white neighbors who previously vowed to hold local abolitionists "responsible for all stealing done in the

${ }^{60}$ Commonwealth v. John W. Allen, August Term 1863, "Indictment: Larceny;" Mercer County Prothonotary Office, Mercer, PA.

61 “September Sessions, 1870," Mercer County Quarter Sessions Docket (April 1869 February 1873) Book 8, pp. 161; Mercer County Clerk of Courts Office, Mercer, PA. 62 “November Sessions, 1867," Mercer County Quarter Sessions Docket (August 1863 April 1869) Book 7, pp. 414; Mercer County Clerk of Courts Office, Mercer, PA.

63 "November Sessions, 1866," Mercer County Quarter Sessions Docket (August 1863 April 1869) Book 7, pp. 290 - 291; Mercer County Clerk of Courts Office, Mercer, PA. 
community," and warned they "might suffer very disagreeably if worse crimes were committed," by the Everett refugees. ${ }^{64}$

Despite the criminal charges some of the Everett refugees faced they did not meet with the same animosity the Randolph refugees faced in Ohio. Not only did the host community not greet them with universal displeasure, but many of their new white neighbors assisted them in the construction of housing. If the Everett refugees had housing during the winter of 1854 - 1855, what should we think of the reports of a tuberculosis epidemic and the subsequent deaths in their community? Although there are no existing records aside from secondary accounts indicating an epidemic, there might be a grain of truth in the legend. Without permanent shelters for everyone, it seems plausible that they shared quarters out of necessity. The warmth provided by close quarters, superseded any temporary inconvenience endured living in close cramped quarters. However, such close quarters lend themselves to spreading contagions quickly. It is likely that the living conditions, although initially crude, were not entirely unfamiliar to the Everett refugees, at least living communally is such tight spaces. The housing most slaveholders provided was certainly not extravagant and satisfied only the most basic definitions of shelter. Enslaved Blacks often found themselves sharing a residence with extended family or even other families. ${ }^{65}$ Even in such tight spaces, most black families took care to maintain sanitary conditions. By the mid- $19^{\text {th }}$ century, slaveholders understood the necessity of hygiene and its impact on the health of enslaved

\footnotetext{
64 Johnson, 231.

${ }^{65}$ Transcript of Interview with Katie Darling, formerly enslaved; interviewed in Marshall, Texas, 2 August 1937; The American Slave: A Composite Autobiography, Vol. 6, Supplement Series 2, Vol. 4, George P. Rawick, ed., (Westport, CT: Greenwood Press, 1979), $1047-1051$.
} 
blacks. Acknowledging hygienic necessity, many slaveholders insisted that their bondspersons take care of their quarters and clean them regularly. ${ }^{66}$ Health concerns arising from the refugees' living quarters probably had more to do with the modest availability of housing as opposed to poor sanitary conditions. Although the winter weather created stress on living accommodations for the Everett refugees, it did not pose an insurmountable barrier. As hard as the first winter may have been for the newly arrived blacks there is no evidence that it took a toll on their population.

Despite the popular stories of a tuberculosis epidemic that nearly wiped out the refugees, the first death did not occur until April of $1855 .{ }^{67}$ In April, Susan Meyers passed away leaving behind two young children, Nick and Lucy Ann. ${ }^{68}$ Susan's death must have arrived with some measure of suddenness; the fiduciary records of the estate make no mention of any medical care she might have received. Conversely, when Rachel Bell died later that year in June, fiduciary records indicate that she was under the care of a physician; one Dr. Hosach. The fiduciary records however, make no mention as to what Dr. Hosach was treating her for or what he prescribed; within the year, Charles Everett, sent $\$ 17$ dollars to the doctor to cover the costs of Rachel's medical bill. The county will books for Albemarle, Virginia, provide clues as to what necessitated Rachel's medical treatment. Records show that Charles Everett, aside from paying Dr. Hosach,

\footnotetext{
${ }^{66}$ Peter Kolchin, American Slavery, 1619 - 1877, (New York: Hill and Wang, 1993), 114.

${ }^{67}$ Christina Greggs, "Pandenarium was a dream that turned into a nightmare," The Sharon Herald, 28 February 2000;

${ }^{68}$ Albemarle County Fiduciary Book \#1, 111; Albemarle County Courthouse, Charlottesville, VA.
} 
also paid Rachel Wheat for her services as a midwife to Rachel Bell. ${ }^{69}$ The need for Wheat's services indicates that Rachel might have died during childbirth or from complications along with the baby, since there is no indication of a surviving child aside from Rachel's daughter, Henrietta, who was already a toddler at the time of her mother's death. ${ }^{70}$ Although such a scenario is plausible, it is by no means definitive. Historian Deborah Gray White points out that for enslaved blacks the role of midwife "extended beyond delivering babies, and they sometimes became known as 'doctor women.",71 Perhaps harsh winter weather contributed to the decline of Susan Meyers, but in the case of Rachel Bell, who died in June, not during the cold winter months, pregnancy and childbirth appears just as likely.

In the five years following their arrival there were only nine deaths among the Everett refugees. In the same period there were 18 births, hardly the mortality rate of a dying community. ${ }^{72}$ Those hardest hit by death were women and children, which is not coincidental considering that in many refugee crises it is the women and children who

${ }^{69}$ Albemarle County Fiduciary Book \#1, 75, and 110 and Albemarle County Will Book \#23, 347; Albemarle County Courthouse, Charlottesville, VA.

${ }^{70}$ Albemarle County Fiduciary Book \#1, 110 and Schedule 1 - Free Inhabitants of East Lackawannock Township in the County of Mercer, State of Pennsylvania, Census Series M653, Roll 1139, 751.

${ }^{71}$ Deborah Gray White, "Female Slaves: Sex Roles and Status in the Antebellum Plantation South," Journal of Family History, 8 (Fall 1983), 248 - 261.

72 The 1860 Federal Census reflects the births among the Pandenarians, while the Albemarle County Fiduciary Records reflect the deaths suffered among the same. Schedule 1 - Free Inhabitants of East Lackawannock Township in the County of Mercer, State of Pennsylvania, Census Series M653, Roll 1139, 103 - 104, 410, 414, and 421 422; and Roll 1140, 750 - 751, and 906. Albemarle County Fiduciary Book \#1, 86, 98, 103, and 109 - 110; Albemarle County Courthouse, Charlottesville, VA. 
endure the greatest degree of hardship. ${ }^{73}$ Of all of the refugee families. however, death affected the Bell family the most. Rachel Bell's death was not the first the family endured nor was it the last. Even before the family arrived in Mercer County, the youngest of Daniel and Nancy Bell's children, Louisa, died in 1849; the child was only three when she passed. ${ }^{74}$ Lucy Jane Bell, another daughter, died in January 1854 , only months before the family boarded the train at Keswick bound for Pennsylvania. ${ }^{75}$ Four years later in 1858, the family suffered its greatest losses; two more of the Bell children died. William and his sister Susan died in July and June respectively. William had lived at home, but Susan was married and had two children of her own when she died. ${ }^{76}$

Susan's widower Willis Lewis was in his mid-twenties when his wife died. The two children of Willis and Susan were both born in Mercer County. The younger of the two children, John, was born in 1858 . His birth date suggests that Susan probably did not die because of an epidemic. Like her older sister Rachel she mostly likely she died from complications due to John's birth. Ironically, Dr. Charles Everett, Sr. was on the cutting edge of women's healthcare when he finished his dissertation in 1795 on the function of

\footnotetext{
${ }^{73}$ Amy Gray and Susan Elliot, "Refugee Resettlement Project 'Refugee Voices': Literature Review," (Wellington: Department of Labour, New Zealand Immigration Service, 2001), $29-30$.

${ }^{74}$ Albemarle County Fiduciary Book \#1, 69; Albemarle County Courthouse, Charlottesville, VA.

${ }^{75}$ Albemarle County Fiduciary Book \#1, 111; Albemarle County Courthouse, Charlottesville, VA.

${ }^{76}$ Albemarle County Fiduciary Book \#1, 69, 75, and 110; Albemarle County Chancery Orders \#5, 1857 - 1860, 231 - 232; Albemarle County Will Book \#23, 337; Albemarle County Courthouse, Charlottesville, VA. Mercer County Deed Book D2, 435 - 436; Mercer County Courthouse, Mercer, PA.
} 
menstruation. ${ }^{77}$ Even under Dr. Everett's care, the birth of a child was fraught with uncertainty for enslaved black women. Strict social mores surrounding gender prevented the rapid development of women's healthcare, and while notions of race clouded the gender line, enslaved Blacks also suffered from the lack of medical knowledge of women's health issues. Childbirth was as much an occasion to fear as it was an occasion to eagerly anticipate. Though medical technology continued to improve throughout the $19^{\text {th }}$ century, it was unable ensure the great joys frequently associated with childbirth today. For Susan Bell Lewis, death and sorrow were as much a part of childbirth as joy and optimism.

As evidenced by the accounting of bills paid to doctors the Everett refugees neither lacked nor refused medical care. Fiduciary records show that the Dr. Everett paid for their care when needed. Although he was certainly not obligated to do so, the younger Everett charity stopped at arranging for care. When presented with the doctors' bills Charles Everett paid them out of the funds set aside by his uncle's estate. Each time a doctor was required, Everett deducted their payment from the accounts of the respective refugees treated. ${ }^{78}$ The access to medical treatment, although no guarantee of good health, at the very least indicates that any epidemic suffered by the Pandenarians would have been well attended and probably equally well documented.

Although decidedly rural, Mercer County, itself was at the center of medical reform in the $19^{\text {th }}$ century. This distinction, however, did not necessarily offer a lot of

\footnotetext{
${ }^{77}$ As a physician, Dr. Charles Everett, Sr., was himself familiar with medical care and childbirth, he wrote his 1795 dissertation on "The Function of Menstruation." The Philadelphia Gazette, 10 June 1795.

${ }^{78}$ Fiduciary records show that medical bills were paid for nearly all of the children in the Bell family. Albemarle County Will Book \#23, 347 - 349; Albemarle County Courthouse, Charlottesville, VA.
} 
great medical knowledge by modern standards. A little more than a year before the arrival of Pandenarians to Mercer, local reformers built a water-cure facility on the edge of town, "Believing ... that all other systems of medical practice [had] substantially failed of their object." ${ }^{, 79}$ The reformers who built the water-cure establishment were part of the same group who advocated the abolition of slavery and assisted in the resettlement of the Everett refugees. The Messrs. Hanna and Stephenson who solicited water-cure doctors in The National Era were active members of the anti-slavery movement in Mercer County. William Stephenson, who was a noted attorney in the county, also served as a trustee for several Everett refugees. ${ }^{80}$ As reform minded members of the community, Hanna and Stephenson solicited doctors to "take charge of the establishment - with science, experience, good address, integrity, honesty and good moral and Christian character." ${ }^{81}$ Undoubtedly, their ideas of "good moral and Christian character" required some dedication to the anti-slavery cause.

The doctors ultimately hired by Hanna and Stephenson did indeed hold to strong anti-slavery ideals. Drs. James and Martha Catlin came from staunch abolitionist families in nearby Warren County, Pennsylvania. James Catlin attended Allegheny College in Meadville, Pennsylvania, just north of Mercer County. While still in college, he engaged in activities supporting the Underground Railroad. ${ }^{82}$ By the time he and his wife arrived in Mercer, he counted Frederick Douglass among his friends. The Catlins remained ardent in their opposition to slavery, writing to Frederick Douglass that they

\footnotetext{
79 "Water Cure Establishment," The National Era, 17 March 1853.

${ }^{80}$ History of Mercer County, Pennsylvania. Its Past and Present, (Chicago: Brown, Runk and Co., Publishers, 1888), 262. Albemarle County Chancery Orders \#5 (1857 1860), 109; Albemarle County Courthouse, Charlottesville, VA.

81 "Water Cure Establishment," The National Era, 17 March 1853.

82 "Remembrances," Mercer Dispatch and Republican, 13 June 1930.
} 
could not "get on, even in a water cure, without ... Anti-Slavery and temperance papers." ${ }^{83}$ James Catlin believed his professional obligations transcended the physical well-being of his patients and required him to attend to their social and moral health as well.

How sick is this world, physically as well as socially and morally! What need of physicians who shall be teachers and reformers? Humanity had been drugged with calomel and quinine, and dosed with rum, and cursed with slavery and dwarfed with land monopoly, and stupefied with tobacco and other narcotics, till there is but little strength of manhood left. ${ }^{84}$

The high moral standards of the new doctors were emblematic of the county's reformers. They were not afraid to preach their doctrines to their neighbors both Black and white.

If the close of the first winter brought any comfort, the ensuing spring quickly dispensed with it. While the land in Mercer was certainly a boon for the refugees, having land did not solve all of their problems nor did it dissolve their uncertainties. Local histories recalled that "The year 1855 was . . . very wet. Grain was harvested with difficulty, much of it being spoiled in the shock." 85 Many of the Everett refugees worked as farmers or farm laborers. Consequently, without a good crop yield they felt an immediate impact economically. For some, the wet spring and resultant crop failures simply meant they paid more at market for foodstuffs. The weather conditions and subsequent growing season in 1855 must have disheartened many of the Everett refugees. This was their first spring in Pennsylvania and, for many working as farmers or farm laborers, and this was their first chance to demonstrate self-sufficiency.

\footnotetext{
${ }^{83}$ James Catlin to Frederick Douglass (25 May 1853), as reprinted in The Frederick Douglass Paper, 3 June 1853.

${ }^{84}$ James Catlin to Frederick Douglass (25 May 1853), as reprinted in The Frederick Douglass Paper, 3 June 1853.

${ }^{85}$ History of Mercer County, Pennsylvania. Its Past and Present, (Chicago: Brown, Runk and Co., Publishers, 1888), 335.
} 
Of the Everett refugees who did not depend directly upon farming for their livelihoods, five were blacksmiths -- George Duke, James Duke, Henry Meyers, Wilson Nicholas, and George Brent. ${ }^{86}$ George Duke and Wilson Nicholas each had the foresight to purchase the tools of their trade from the estate. James Duke and Henry Meyers did not purchase any tools from the Everett Estate and would have found it difficult to acquire tools upon their arrival, as both were indebted to the estate. The fifth blacksmith, George Brent, might have had tools, but he did not purchase them from the estate. Unlike many of their peers, the Duke Brothers, Henry Meyers, Wilson Nicholas, and George Brent had skills and in some cases tools to assist them in their resettlement.

As the senior blacksmith and only bachelor of the group, Wilson Nicholas had little else upon which to spend his share of the estate. Of all the refugees, Wilson was the only one without any family relations. Although the estate records reveal he paid $\$ 59.00$ for tools, they do not state specifically whether those were tools of his trade or perhaps tools for carpentry or farming. At 55, Wilson Nicholas was not a young man, but he was not unable to support himself by his own labors either. Nicholas held either no claim or very little claim to land in Mercer County. Charles Everett's agent filed a deed on Nicholas's behalf in the county courthouse and Nicholas made his mark upon it, but the deed gives no indication of any land acquired in Mercer. In 1860, Wilson Nicholas was living with George Duke in the town of Mercer. ${ }^{87}$ As both were smiths, it is plausible

\footnotetext{
${ }^{86}$ Albemarle County Fiduciary Book \#1, 70; Albemarle County Courthouse, Charlottesville, VA.

${ }^{87}$ Albemarle County Fiduciary Book \#1, 70; Albemarle County Will Book \#23, 345; Albemarle County Courthouse, Charlottesville, VA. Mercer County Deed Book D2, 437 - 438; Mercer County Courthouse, Mercer, PA; Schedule 1 - Free Inhabitants of Mercer in the County of Mercer, State of Pennsylvania, Census Series M653, Roll 1139, 421 422.
} 
that they shared a business and the workload, at least for a few years. By 1860 though, Nicholas was near sixty and may have retired from the heaviest of the smithing tasks.

Although he accompanied the Everett refugees, George Brent was never a bondsman of Dr. Charles Everett, Sr. Brent's connection to the group in Virginia remains somewhat of a mystery. In 1855 , he married into the Lewis family when he exchanged marital vows with Mary Jane Lewis. ${ }^{88}$ The Lewises were one of the families formerly enslaved by Dr. Everett. Brent was not the only free black to accompany the former Everett bondspeople north. Three brothers, John, William and James Garland also joined the Everett refugees, as well as three women: Caroline Lewis, Sarah Watson, and Agnes Duke. Agnes and Caroline were married to Windsor Duke and George Lewis, Jr., respectively. Both Duke and Lewis had been bondsmen under Dr. Everett. After Willis Lewis's wife, Susan, died in 1858, he married Sarah Watson. ${ }^{89}$

While not necessarily as skilled as the blacksmiths within their group, the other Everett refugees were not without resources if the growing season returned a poor yield. As of December 1, 1854, the Everett Estate owed the Everett refugees, $\$ 38,374.61$ collectively. The estate owed the average refugee $\$ 938.96$, a considerable amount for any black settler anywhere in the United States. ${ }^{90}$ These dollar amounts were in addition to their landholdings. So even as foul weather threatened the local economy, if they needed to, the refugees could tap into funds owed them by the Everett Estate. When the

${ }^{88}$ Albemarle County Fiduciary Book \#3, 10; Albemarle County Chancery Orders \#5, (1857 - 1860), 233; Albemarle County Courthouse, Charlottesville, VA.

${ }^{89}$ W. Edward Weidhmann, "Indian Run History Compiled By Educator," The New Wilmington Globe, 22 August 1973; Schedule 1 - Free Inhabitants of Mercer in the County of Mercer, State of Pennsylvania, Census Series M653, Roll 1139,104.

${ }^{90}$ Albemarle County Will Book \#23, 353; Albemarle County Courthouse, Charlottesville, VA. 
refugees arrived in Mercer County, each Everett refugee was entitled to $\$ 1425.76$ as of October 1854. Although some like George Duke spent much of their shares purchasing the freedom of their loved ones, others like Old Lucy arrived in Mercer with access to more than $\$ 800.00 .^{91}$ There is little doubt that the refugees requested and received significant funding from the estate in the first three years after their arrival in Mercer County. By February 1, 1857, the original sum of more than $\$ 38,000.00$ dwindled to $\$ 12,938.77$, leaving each with a share of $\$ 331.76 .^{92}$

The expenditures of each refugee differed. Some, like Rachel Bell and her sister Susan Bell Lewis, paid out money for medical expenses, clothing and ultimately funerals. Others, like George Duke, began their new lives in Mercer County in the negative. They used significant portions of their shares to purchase the freedom of spouses and children. George Washington Duke was 47 in 1854 . He had worked as a blacksmith in Virginia and his share of the four lots indicates he probably continued as a blacksmith in Pennsylvania. Like his father, George was married to a woman held in bondage by another slaveholder in Virginia. However, George was able to secure his wife's freedom with his share of the Everett estate. Along with his wife, Harriet, George Duke purchased the freedom of his three sons, Reuben, Charles, and Joseph. All told, George used $\$ 1600.00$ to purchase his family's freedom from M.L. Walker. Obviously concerned for the support and welfare of his family, George had the foresight to purchase his blacksmithing tools from the Everett estate for and additional $\$ 61.32$. George had leveraged his past and present for the potential of his and his family's future. All of his

\footnotetext{
${ }^{91}$ Albemarle County Will Book \#23, 331; Albemarle County Courthouse, Charlottesville, VA.

92 Albemarle County Fiduciary Book \#1, 72; Albemarle County Courthouse, Charlottesville, VA.
} 
expenditures left George indebted to the estate. When he arrived in Mercer County, George owed the Everett estate $\$ 680.79 .^{93}$

Ironically, George Duke and his family were some of the few refugees to make financial gains after relocating to Mercer. While George Duke began his new life in debt, what he had working in his favor were his skills and his diligence as a blacksmith, as well as the assistance of his sons. Within six years of his arrival in Mercer, George settled his debt to the Everett estate. By 1860 then, George had received his entire share of the Everett estate. According to the federal census, that same year George Duke owned $\$ 1500.00$ in real estate, and claimed $\$ 1000.00$ in personal property. ${ }^{94}$ Of Duke's real estate, his home accounted for the largest portion; when originally purchased in 1854 the house sold for $\$ 850.00 .^{95}$ Likewise, blacksmithing tools comprised much of the value or George Duke's personal estate. ${ }^{96}$ To put Duke's financial fortunes into perspective, James Kilgore, a white blacksmith in the borough of Mercer, claimed \$2800.00 in real estate, but only $\$ 300.00$ in personal property. ${ }^{97}$

If George Duke had any setbacks in Mercer County, certainly his indictment for the illegal sale of liquor was the most prominent. Whether or not Duke was convicted is unknown because the respective court records no longer exist. In any case, what is clear is that by 1870 , George Duke and his family no longer called Mercer, nor any other part

\footnotetext{
${ }^{93}$ Albemarle County Will Book \#23, 341 and 353; Albemarle County Courthouse, Charlottesville, VA.

${ }^{94}$ Ibid. Schedule 1 - Free Inhabitants in Mercer in the County of Mercer, State of Pennsylvania, Census Series M653, Roll 1139, 421

${ }^{95}$ Mercer County Deedbook D2, 426 - 427; Mercer County Courthouse, Mercer, PA.

${ }^{96}$ Duke purchased his blacksmithing tools from the Everett estate at a cost of $\$ 61.32$. Albemarle County Will Book \#23, 341; Albemarle County Courthouse, Charlottesville, VA.

${ }^{97}$ Schedule 1 - Free Inhabitants in Mercer in the County of Mercer, State of Pennsylvania, Census Series M653, Roll 1139, 422.
} 
of Pennsylvania, home. His ability to overcome his debts and accrue some measure of prosperity might lead observers to believe he was comfortable in Mercer. Certainly, many of his contemporaries would have openly questioned his desire to leave a lucrative blacksmithing business to move and re-establish his family in another state. His legal troubles might offer some clues to his abrupt departure. If convicted, George Duke faced stiff fines and risked his reputation as a reputable businessperson. Many of the white abolitionists in Mercer County were devoted to the temperance movement. ${ }^{98}$ Even if the legal system found Duke innocent, the charges and subsequent indictments alone potentially sullied his reputation in the borough. In the end, Duke might have found it easier to relocate and re-establish his business where he still enjoyed a solid reputation or at least no reputation at all.

Despite the assumptions, accusations, and indictments, the Everett refugees proved themselves resourceful. With a bad shoulder and his advanced age working against him, Old Joe Duke moved in with his daughter Rose Allen and her husband John. By 1860 , Old Joe was close to 80 years old, but he managed to do his part to help the family. According to the 1860 Census, Old Joe worked at home as a basket maker. ${ }^{99}$ With three young children in the house, the Allens could ill afford for Old Joe to sit idle. Old Joe's son-in-law, John Allen, was a farmer and landowner who worked 100 acres in East Lackawannock Township. Census takers reported his real estate holdings were

\footnotetext{
${ }^{98}$ Both William Clarke, Jr. and James Catlin, both active abolitionists, pledged their devotion to the temperance movement in their letters and diaries. "Diary of W. F. Clarke, Jr., Mercer, Pa, January 10, 1862," Historical Society of Western Pennsylvania; Pittsburgh, PA. James Catlin to Frederick Douglass (25 May 1853), as reprinted in The Frederick Douglass Paper, 3 June 1853.

${ }^{99}$ Schedule 1 - Free Inhabitants of East Lackwannock in the County of Mercer, State of Pennsylvania, Census Series M653, Roll 1139, 204.
} 
worth $\$ 2800.00$ and that he owned an additional $\$ 900.00$ in personal property. ${ }^{100}$ The Allens's real and personal estate exceeded that of the neighboring Pandenarians. Living in close proximity were the Reeves, Windsor Duke, Watson, George Lewis, and Willis Lewis households. Those families' combined real estate value was $\$ 5400$, supplemented by $\$ 1220$ in personal estates. ${ }^{101}$

Although well off by refugee standards, the Allens lagged behind their white neighbors in East Lackawannock Township in terms of real estate and personal property values. The five refugee families in East Lackawannock combined, owned less than their two closest white neighbors. ${ }^{102}$ George and Willis Lewis, William Reeves and Ed Watson all worked as farm laborers. Whether or not they worked for or with John Allen is unclear. However, the fact that they had to work as laborers outside of their own homesteads indicates that their existence may not have been as comfortable as that of John Allen. None of their white neighbors, worked as laborers outside of their own farms. ${ }^{103}$ For all that they lacked in financial resources individually, the Everett refugees in East Lackawannock Township worked together to support other refugees. The Reeves and Watson families took in children who were not their own, while both Lewis families took in adults and children. Jane Richards, a twenty-two year old washerwoman lived with George and Caroline Lewis. Jane may have been related to Caroline, as both were

${ }^{100}$ Mercer County Deedbook D2, 428; Mercer County Courthouse, Mercer, PA. Schedule 1 - Free Inhabitants of East Lackawannock in the County of Mercer, State of Pennsylvania, Census Series M653, Roll 1139, 203 - 204.

${ }^{101}$ Schedule 1 - Free Inhabitants of East Lackawannock in the County of Mercer, State of Pennsylvania, Census Series M653, Roll 1139, 203 - 204.

102 The two white families totaled $\$ 5500.00$ in real estate and $\$ 2000.00$ in personal estate properties. Schedule 1 - Free Inhabitants of East Lackawannock in the County of Mercer, State of Pennsylvania, Census Series M653, Roll 1139, 203 - 204.

${ }^{103}$ Ibid. 
native to Pennsylvania and had not come from Virginia like the other Pandenarians.

Willis Lewis and his wife Sally took in Sally's younger sisters after their mother Letitia died in 1859. They also took in Milly Tucker, who at thirty years of age needed less care and more financial support. ${ }^{104}$

For the refugees south of the borough of Mercer, the Allen household took on special significance. The relative affluence of the Allen family and Old Joe's presence contributed to the household's importance to the Everett refugee community. Old Joe was, after all, the patriarch of the refugees and related to many of the other households. The Allen household became the spiritual and social center of the Pandenarian community. Although, no village named Pandenarium ever really existed in Mercer County, some of the basis for this legend might rest in the activities of the Allen farm. Religious gatherings and "singings" took place at the Allen farm. ${ }^{105}$ The religious gatherings reflect the tight-knit sense of community among the Pandenarians, and perhaps suggest their sense of being outsiders. Despite the presence of White Chapel, a Baptist, and two Presbyterian congregations, refugees chose (or were perhaps unwelcome) not to worship with their white neighbors. The Presbyterian and Baptist congregations were established in 1854, the same year the Everett refugees arrived, but do not appear linked. ${ }^{106}$

${ }^{104}$ Ibid. Albemarle County Fiduciary Book \#3, pp. 5; Albemarle County Courthouse, Charlottesville, VA.

${ }^{105}$ Johnson, 231. W. Edward Weidhmann, "Indian Run History Compiled by Educator," The New Wilmington Globe, 22 August 1973. "Indian Run Area About 1900," undated map and legend, Mercer County Historical Association, Mercer, PA.

${ }^{106}$ History of Mercer County, Pennsylvania, (Philadelphia: L.H. Everts and Co., 1877), 29 and 81. 
Rose Allen's nickname, Aunt Rosy, also indicates that the Allens (and Rose in particular) enjoyed a measure of respect among the refugees. In her obituary in 1908, The Mercer Dispatch recalled that Rose Allen "was respected by all who knew her."107 That same respect helped reinforce the importance of the Allen household to the Everett refugees south of Mercer. By 1870, Old Joe had passed away, but the Allen farm remained a fixture for the refugees. William Reeves and his family moved in with the Allens. William was roughly 70 years old at the time and, according to census records, was either deaf or blind by that point. ${ }^{108}$ Even though Reeves worked as a farm laborer while in Mercer County, he had apparently worked hard and saved enough money to acquire land of his own. In 1860, he owned no real estate of any value; ten years later, William Reeves owned real estate valued at $\$ 1500.00 .^{109}$ Although then living with the Allens, Reeves did not sell his land, perhaps saving it for the benefit of his children. Over the same decade, the Allens witnessed their real estate property value increase dramatically; their $\$ 2800.00$ in real estate property ballooned to $\$ 11,500.00$ in $1870 .{ }^{110}$

The Allens were not the only Everett refugee family to benefit from appreciating property values. In neighboring Springfield Township, Daniel Bell and his wife Nancy also benefitted from appreciating property values. Like their cousins, the Allens, the Bell family saw their real estate property value more than double, going from $\$ 1200.00$ in 1860 to $\$ 2800.00$ in 1870 . Likewise, Daniel Bell’s personal property value increased

\footnotetext{
107 “Recent Deaths," The Mercer Dispatch, 13 March 1908.

${ }^{108}$ Schedule 1 - Free Inhabitants of East Lackawannock in the County of Mercer, State of Pennsylvania, Census Series M593, Roll 1373, 49.

${ }^{109}$ Ibid. Schedule 1 - Free Inhabitants of East Lackawannock in the County of Mercer, State of Pennsylvania, Census Series M653, Roll 1139, 204.

${ }^{110}$ Ibid.
} 
from $\$ 250.00$ to $\$ 480.00 .{ }^{111}$ While it might be easy to declare the Bell family reasonably successful, their property values increased in some measure through family consolidation. The Bells, more than any other refugee family, were visited by death. Five of Daniel and Nancy's children died between 1849 and 1858. Their daughter Louisa passed away even before the family migrated to Pennsylvania, and was only a child when she died. According to the terms of the Everett estate, her portion of the inheritance went to her parents. In the case of their daughter, Lucy Jane, she died leaving a young daughter and no spouse. Daniel and Nancy took in their granddaughter, but in doing so assumed responsibility for her support and maintenance. Still, their granddaughter was no great financial burden, since she was entitled to a portion of the Everett estate.

Generally, most of the Everett refugees did well enough to get by but did not increase their collective wealth appreciably. Some, however, were not able to maintain their modest socioeconomic standings upon their arrival in Mercer County, and slipped into poverty or away from the area. In 1860, Wilson Nicholas lived with George Duke and his family in the borough of Mercer. Both men were blacksmiths by trade, and although Nicholas was not a young man when he arrived in Pennsylvania, he was not so old as to prohibit him from working. Nonetheless, while he lived with the Dukes the census reported no occupation for Wilson Nicholas in $1860 .{ }^{112}$ Ten years later, the Dukes

${ }^{111}$ Schedule 1 - Free Inhabitants of Springfield Township in the County of Mercer, State of Pennsylvania, Census Series M653, Roll 1140, 751. Schedule 1 - Free Inhabitants of Springfield Township in the County of Mercer, State of Pennsylvania, Census Series M593, Roll 1374, 135.

112 Schedule 1 - Free Inhabitants in Mercer in the County of Mercer, State of Pennsylvania, Census Series M653, Roll 1139, 421 - 422. Albemarle County Fiduciary Book \#1, 70; Albemarle County Will Book \#23, 345; Albemarle County Courthouse, Charlottesville, VA 
had left Mercer County, and Wilson Nicholas was a resident of the county Almshouse. ${ }^{113}$ Nicholas's descent into poverty happened quickly. Unlike the other refugees, Wilson Nicholas had no family, either immediate or extended, when he left Virginia. As he aged, Wilson Nicholas depended on his fellow Everett refugees and the estate to provide for his needs. Unfortunately for Nicholas, the departure of George Duke and his family was not his only setback. Support from the Everett estate ceased in 1860, as Nicholas had received his entire settlement by that time. Without the Dukes or the financial support of the Everett estate, Nicholas had no means to support himself. ${ }^{114}$

George Duke was not the only Everett refugee to arrive in Mercer beholden to the Everett estate. George's brother James, his sister Letitia Robertson, and Henry Myers all owed money to the estate upon arrival in Mercer County. Collectively the four owed the estate a total of $\$ 1758.74 .^{115}$ Each used monies to buy the freedom of their spouses and children. Like her older brother, Letitia Robertson bore the expense of liberating her spouse; she paid \$675.00 to F.G. Ruffin for Jackson Robertson's freedom. Letitia and her husband Jackson arrived in Mercer County with nine children. Unlike her brothers, George and James, Letitia did not have to purchase the freedom of her children. The third indebted Duke sibling, James, was, like George, a blacksmith. To buy his wife Elizabeth and two year old son Samuel from W.M. Smith, James Duke paid $\$ 850$. The

${ }^{113}$ Schedule 1 - Free Inhabitants in Coolspring Township in the County of Mercer, State of Pennsylvania, Census Series M593, Roll 1374, 11.

${ }^{114}$ Albemarle Chancery Orders \#6, (1860 - 1867), 52; Albemarle County Courthouse, Charlottesville, VA.

115 Albemarle County Will Book \#23, 353; Albemarle County Courthouse, Charlottesville, VA. 
expenditures left James $\$ 350.98$ in arrears with the estate. ${ }^{116}$ Henry Myers was the only other refugee who owed money to the Everett estate. Henry's wife, Sophia, and his two children William and Jerry cost the blacksmith $\$ 1300$. The money paid for his family went to Charles Everett, Jr., who claimed the rest of the Myers family as his chattel. Relocating his family in Lackawannock Township left Henry Myers in debt to the Everett estate for $\$ 565.80 .^{117}$

While the expense of freeing loved ones left George and James Duke, Letitia Robertson, and Henry Meyers indebted, other Everett refugees purchased the freedom of their loved ones without falling into debt. Nancy Bell and William Rives each used portions of their inheritance to free their spouses. None of them bore the additional expense of having to purchase any children. This was extremely fortunate in Nancy's case as she was the mother of nine children. The expense of freeing all nine children and her husband would have exceeded her financial resources and left her with painful decisions to make. William Rives was able to purchase the freedom of his wife Lucy, but she passed away just prior to $1860 .{ }^{118}$

A third group of Everett refugees would gladly have sunken into to debt to free their loved ones but were unable to do so. Lucy Jane and Rachel Bell, both of whom died by 1855 , were unable to purchase the freedom of their respective husbands. Perhaps the loss of their husbands affected their health as they looked to move to Pennsylvania. Both

\footnotetext{
${ }^{116}$ Mercer County Deedbook D2, 433 - 435; Mercer County Courthouse, Mercer, Pennsylvania.

${ }^{117}$ Albemarle County Fiduciary Book \#1, 70; Albemarle County Will Book \#23, 335; Albemarle County Courthouse, Charlottesville, VA. Mercer County Deed Book D2, 445 - 446; Mercer County Courthouse, Mercer, PA.

${ }^{118}$ Schedule 1 - Free Inhabitants of East Lackawannock Township in the County of Mercer, State of Pennsylvania, Census Series M653, Roll 1139, 103 - 104.
} 
women faced the task of raising children on their own; both had daughters under the age of three in 1854. ${ }^{119}$ Like the Bell sisters, Susan Meyers was unable to purchase the freedom of her husband, and in eerie parallel, Susan too died within the first year of the refugees' arrival in Mercer County, leaving behind two small children. ${ }^{120}$ The other Everett refugee who was unable to purchase the freedom of his spouse was Ed Watson. Unlike the women, Ed Watson had no children to care for and, although he came to Mercer alone, he did not remain so for long. Watson married Rachel and Lucy's younger sister Judy shortly after the refugees settled into Mercer County. ${ }^{121}$

Despite the loss of loved ones either to death or because of separation arising from slavery, some of these refugees were able to rebuild their lives in Mercer County. Willis Lewis, Ed Watson, William Reeves, and Jackson Robertson all remarried and either added to their families or started new ones. In the years following their arrival in Pennsylvania, the Everett refugees multiplied their numbers and offset any losses to their numbers. ${ }^{122}$ As the children got older, some married, leaving the care of their parents and court appointed guardians. Sally Watson, Judy Bell, and Mary Jane Lewis all married while still minors. In doing so, the responsibility for their financial support fell upon

\footnotetext{
${ }^{119}$ W. Edward Weidhmann, "Indian Run History Compiled By Educator," The New Wilmington Globe, 22 August 1973; Albemarle County Fiduciary Book \#1, 75, and 110 111 and Albemarle County Will Book \#23, 347; Albemarle County Courthouse, Charlottesville, VA.

${ }^{120}$ W. Edward Weidhmann, "Indian Run History Compiled By Educator," The New Wilmington Globe, 22 August 1973; Albemarle County Fiduciary Book \#1, 111; Albemarle County Courthouse, Charlottesville, VA.

${ }^{121}$ W. Edward Weidhmann, "Indian Run History Compiled By Educator," The New Wilmington Globe, 22 August 1973; Albemarle County Chancery Orders \#5, (18571860), 231; Albemarle County Courthouse, Charlottesville, VA.

${ }^{122}$ Schedule 1 - Free Inhabitants of East Lackawannock Township in the County of Mercer, State of Pennsylvania, Census Series M653, Roll 1139, 103 - 104, 410, 414, and 421 - 422; and Roll 1140, 750 - 751, and 906.
} 
their new husbands. All three married within the Pandenarian community. Sally married Willis Lewis, Judy married Ed Watson, and Mary Jane married George Brent. ${ }^{123}$ These marriages within the Pandenarian community ensured that the legacy of the Everett estate also stayed within the community. For men like Ed Watson and Willis Lewis it meant they had access to a greater portion of the estate due to their wives' inheritance.

Yet another group of Everett refugees who were not able to secure the freedom of all of their loved ones, proved unable to start anew in Mercer County. Not all of the Everett refugees were at an age where they were looking to marry and raise families. Several of the refugees were older and needed assistance from others to survive. The patriarch of the Everett refugees, "Old" Joe Duke arrived in Mercer County at the age of 75. Joe had lived nearly his entire life enslaved, and had the misfortune of leaving behind a spouse and children. When he arrived in Mercer County, Joe had already outlived ten of his children, and though seven more came to Mercer County with him another three remained enslaved in Virginia. ${ }^{124}$ Old Joe did not gain any extensive land holdings in the county; this was probably reflective of his personal limitations, age and physical condition. Although Joe was "of sane mind and good general health," he had a separated shoulder, which he had apparently lived with for many years. ${ }^{125}$ He had a two-thirds share of four lots on the corner of Pear Alley and Shenango Street. On one of those lots,

${ }^{123}$ Albemarle County Chancery Orders \#5, (1857 - 1860), pp. 234 and Albemarle County Fiduciary Book \#3, pp. 10; Albemarle County Courthouse, Charlottesville, VA.

${ }^{124}$ Hubert Rex Johnson, A History of the Neshannock Presbyterian Church, (Washington, D.C.: National Capitol Presbytery, Inc., 1925), 231.

${ }^{125}$ Albemarle County Fiduciary Book \#1, 70; Albemarle County Courthouse, Charlottesville, VA. 
Dr. Everett had purchased a house for Old Joe. The remaining one-third share on the corner belonged to Old Joe's son, George. ${ }^{126}$

The purchase of a house for Old Joe may be the basis for one of the abiding myths of Pandenarium; all of the settlers arrived to find fully furnished homes. This was most certainly not the case for the other Everett refugees. Only Joe received a house as part of his share of the estate. Records of the Albemarle Chancery courts suggest that Charles Everett, Jr. could provide, if he chose to, houses or anything else that, "in his judgment shall best promote their comfort and prosperity."127 Although the courts left the door open for Everett to exercise his own discretion, the fiduciary records for Albemarle County leave no indication that he ever set aside money for the construction or purchase of homes for his uncle's former chattel, with just one exception. Furthermore, since the records are rather thorough, detailing even the general health and age of all those moving north to Pennsylvania, it is probably safe to conclude that he never allocated any money for houses other than Old Joe's. ${ }^{128}$

Joe Duke was not the only senior member of the Everett refugees, “Old” Lucy Myers was 70 and Joe's brother-in-law, Mike Johnson was $75 .^{129}$ Like Joe Duke, Lucy came to Mercer County with no spouse and few occupational prospects. In 1860, Lucy

${ }^{126}$ Mercer County Deedbook D2, 426 - 427; Mercer County Courthouse, Mercer, PA and Albemarle County Will Book \#23, 341; Albemarle County Courthouse, Charlottesville, VA.

${ }^{127}$ Albemarle Chancery Court Orders \#3, (1849 - 1854), 455; Albemarle County Courthouse, Charlottesville, VA.

${ }^{128}$ The fiduciary records of Albemarle County, describe the general health, age and kinship of all of the former Everett bondspersons emancipated by Dr. Charles Everett's will. Albemarle County Fiduciary Book \#1, 69 - 70; Albemarle County Courthouse, Charlottesville, VA.

${ }^{129}$ Albemarle County Fiduciary Book \#1, 69 - 70; Albemarle County Courthouse, Charlottesville, VA. 
was living with George Brent and his family in the census that year she gave 99 as her age. The other senior refugee, Mike Johnson, was in decent health when he arrived in 1854. It was Johnson who built the coffins for Rachel Bell and Susan Myers. But by 1860, Mike Johnson did not appear in the census and he ceased to appear in the fiduciary records in Albemarle County at the same time. ${ }^{130}$ Aside from his brother-in-law, Old Joe, Mike Johnson had no immediate family in Mercer County to whom to pass along his share of the Everett estate. ${ }^{131}$

As older members of the Everett refugees passed away, the land holdings increasingly consolidated into larger farms controlled by fewer and fewer families. As the land holdings of the refugees consolidated, many settled their accounts with the Everett estate. By 1860, most of the Everett refugees had settled with the estate, and those who had not done so gradually settled over the next ten years. ${ }^{132}$ The settlement of the Everett estate and the end of the Civil War gave the Everett refugees the independence they eagerly anticipated in 1854 . The settlements also severed any lingering dependencies to the Everett estate. Some of the original refugees stayed on in Mercer County; Aunt Rose Allen remained there until 1907, a year before she died. ${ }^{133}$ Others like George Duke chose not to stay. By 1870, Mercer County had outlived its usefulness as refuge from slavery. For the remaining Everett refugees and their

${ }^{130}$ Albemarle County Fiduciary Book \#1, 75, and 110 and Albemarle County Will Book \#23, 347; Albemarle County Fiduciary Book \#1, 111; Albemarle County Courthouse, Charlottesville, VA.

${ }^{131}$ Albemarle County Fiduciary Book \#1, 69 - 70; Albemarle County Courthouse, Charlottesville, VA.

${ }^{132}$ Albemarle County Chancery Orders, \#6 (1860 - 1867), 52; Albemarle Chancery Orders, \#7 (1868 - 1872), 163 and 512; Albemarle County Courthouse, Charlottesville, VA.

133 "Recent Deaths," The Mercer Dispatch, 13 March 1908. 
descendents, they had the chance to determine for themselves what was in their best interest, without legal restrictions from the Virginia courts or the institution of slavery. 


\section{CHAPTER 6}

\section{THE LONG AND WINDING ROAD TO FREEDOM}

We have been standing comparatively still for years, following in the footsteps of our friends, believing that what they promise us can be accomplished, just because they say so, although our own knowledge should long since, have satisfied us to the contrary. ${ }^{1}$

- Martin R. Delany

The Black refugees who came to Mercer County between 1820 and 1860 did so in diverse fashions and at different times. Black refugees began appearing and settling in numbers shortly after 1820 . Those first refugees who settled a community they called Liberia risked life and limb to attain the freedom denied them in their homelands. They did not all arrive together; instead, they trickled in over the next thirty years as individuals or in small groups. Frequently, they appeared in Mercer County with nothing more than the clothes on their backs. Their sometimes tattered and beleaguered appearance reflected the abruptness of their departures and the lack of detailed planning prior to their journey. Conversely, the refugees who arrived as a group in 1854 did so in relative comfort. Their journey to freedom began years earlier with the death Charles Everett, who manumitted his enslaved chattel posthumously in his will. Their trip from Charlottesville, Virginia, began aboard a train and ended in wagons in the borough of Mercer, Pennsylvania. They began their lives as free persons with financial resources bequeathed them by Everett. Despite the obvious differences in their arrivals, both the Liberians and Everett people shared a refugee experience; both hoped to escape the

\footnotetext{
${ }^{1}$ Martin Robison Delany, The Condition, Elevation, Emigration, and Destiny of the Colored People of the United States (Reprint Edition. Salem, New Hampshire: Ayer Company Publishers, Inc., 1988), 190.
} 
oppression of bondage and seize their freedom. For all of the black refugees in Mercer

County, their stay in Mercer was but one stop on their long road to freedom.

The journey from danger and oppression to refuge, for most refugees, is a multistep process. Sociologist Egon F. Kunz found that,

involuntary migrations leading to re-settlement in a non-adjacent country (and such migrations are not a negligible proportion) are not necessarily single-step movements connecting an origin and a destination point in a single line. ${ }^{2}$

Kunz indentified three kinetic models, which characterize the movement of refugees from their homelands to refuge: acute, anticipatory, and intermediate. Kunz's models reflect the urgency of flight and the subsequent planning involved. An abrupt departure resulting from a specific event characterizes the acute model. Frequently there is little or no planning in an acute movement, as the refugees behave in reactionary fashion. In an acute movement,

the refugees leave their homeland on a moment's notice. They have not planned or prepared for their journey; they are not looking at their future; they are simply trying to get out of harm's way. ${ }^{3}$

Conversely in an anticipatory movement,

refugee[s] sense the danger early, before a crisis makes orderly departure impossible. Superficially the anticipatory refugee resembles the voluntary migrant. The whole family moves, brings resources with them, and has made preparations for a new life. ${ }^{4}$

A renewed threat across political boundaries typifies the third, intermediate model.

Although the refugees may have crossed into friendlier territories by crossing a political

\footnotetext{
${ }^{2}$ Egon F. Kunz, "The Refugee in Flight: Kinetic Models and Forms of Displacement," International Migration Review, Vol. 7, No. 2. (Summer, 1973), 126.

${ }^{3}$ Barry Stein, "The Refugee Experience: Defining the Parameters of a Field Study," Inernational Migration Review, Vol. 15, No. 1/2, Refugees Today. (Spring - Summer, 1981), 322.

${ }^{4}$ Ibid.
} 
boundary, conditions in their homeland might threaten them in their adopted homes.

These kinetic models, then, either independently or in combination with one another, help explain the motivations and subsequent movements of refugees. ${ }^{5}$

Central to Kunz's kinetic models is the pressure or push impetus in taking flight. Kunz argued that it is inaccurate to define refugee crises with push - pull factors as indicated by earlier refugee studies. Instead, he argues, "the 'pull' is either lacking in spontaneity or is totally absent," in a refugee crisis. ${ }^{6}$ In short, the feeling or perception that someone or something pushes the refugee out of their homeland overwhelms any sense that greater opportunity might pull them abroad. According to Kunz, conditions within their homeland push refugees out. Conversely those pulled out by opportunities elsewhere more likely to be voluntary migrants. This distinction between voluntary and involuntary migration creates a very fine line, which is sometimes blurred. Though Kunz recognized the difficulty in qualifying the push in the involuntary migrations,

The validity of fear for one's safety which is the creator of all refugees can after all never be tested: it is the individual's interpretation of events and self perceived danger or revulsion, or role, which motivates the refugee and justifies his stand. ${ }^{7}$

Ultimately, it is not the crossing of an international border that defines refugee status.

Instead refugees are defined by their reluctance to uproot or relocate, and an "absence of positive original motivations to settle elsewhere."

\footnotetext{
${ }^{5}$ Kunz's three movement models include Acute, Intermediate, and Anticipatory. Egon F. Kunz, "The Refugee in Flight: Kinetic Models and Forms of Displacement," International Migration Review, Vol. 7, No. 2. (Summer, 1973), 134 - 136.

${ }^{6}$ Ibid., 134.

${ }^{7}$ Ibid., 136.

${ }^{8}$ Ibid., 130.
} 
Two of the three models fit the experience and movement of the Liberian refugees. The initial movement of the Liberian refugees was acute; they left their homelands with little to no planning beyond the immediate. Their abrupt and reactionary movements responded to the existing threat of bondage. The Liberian refugees arrived in Mercer County largely by their own devices. Unlike the later Everett refugees, they gained their freedom by escaping from bondage. Although they may not have planned to settle in Pennsylvania, the state's abolition of slavery in 1780 and its subsequent antikidnapping laws provided a safe haven for Blacks escaping bondage.

Shortly after 1850 , however, the Liberians again took flight, and what began as an acute movement became an intermediate movement. Liberians responded to a Supreme Court decision and subsequent developments in federal legislation. Rather than face the possibility of re-enslavement they chose to move again. The first attack on the safe haven came in 1842. The Supreme Court found Pennsylvania's anti-kidnapping law unconstitutional in Prigg v. Pennsylvania (1842). The decision nationalized a slaveholder's right to property, and by extension slavery, but at the same time it created a loophole for Black refugees. Although nationalized, the court ruled that the recapture of "fugitive slaves" fell under federal jurisdiction. ${ }^{9}$ As such, the Fugitive Slave Act of 1793 could not compel state and/or local authorities to assist in the recapture of escaped chattel. This loophole created difficulties for slaveholders to recover their lost property; consequently, they sought greater assistance from the federal government.

The increased assistance from the federal government came in the form of the Fugitive Slave Act of 1850. The new Fugitive Slave act closed the loophole created by

${ }^{9}$ Prigg v. Pennsylvania, 41 U.S. 16 Peters 539 (1842). 
the Prigg decision and required state and local authorities to assist in the recapture of escaped chattel. The passage of the act demolished the refuge Pennsylvania offered to Black refugees escaping from bondage. Denied continued refuge in the commonwealth, Liberian refugees left en masse for Canada. The departure of the Liberians signaled an end to their Mercer County community, but it did not necessarily mark Liberia as a failure. Liberians came to Pennsylvania seeking freedom and self-determination; they found it in the commonwealth so long as slave catchers remained only a distant threat. The passage of the Fugitive Slave Act of 1850 did not strip them of their freedom but it did force them to look elsewhere to maintain it.

Like the Liberians, the later refugees to arrive in Mercer County, the Everett people, also experienced "refugee movements . . . as multiple-step acts with interruptions of important special and temporal aspects. ${ }^{" 10}$ Unlike their predecessors however, the Everett refugees' transition was more subtle and less abrupt. “There are refugees who leave their home country prepared, with transport prepaid and with clear knowledge of destinations," according to Kunz. The Everett people were just such a group. ${ }^{11}$ They anticipated the threat of re-enslavement, which prompted their departure from Virginia. Their freedom depended upon their acquiescence to the wishes of Charles Everett. They could if they wished, refuse the relocation and resettlement scheme, but any refusal denied them access to their financial stake in the Everett estate. Perhaps even more troubling, their refusals threatened them with re-enslavement. ${ }^{12}$ Virginia legislation

\footnotetext{
${ }^{10}$ Egon F. Kunz, "The Refugee in Flight: Kinetic Models and Forms of Displacement," International Migration Review, Vol. 7, No. 2. (Summer, 1973), 126.

11 Ibid., 131.

${ }^{12}$ Albemarle Chancery Court Orders \#3, (1849 - 1854), 456; Albemarle County Courthouse, Charlottesville, VA.
} 
mandated that all blacks emancipated after 1806, had one year to leave the state or face re-enslavement. ${ }^{13}$ Authorities however, enforced the law unevenly and largely at the local level. In Albemarle County, the local courts did not overtly threaten the Everett people, but enthusiasm for colonization made the possibility of re-enslavement more likely. To avoid re-enslavement and to seize their freedom the Everett people opted to leave Virginia.

The relocation of the Everett people required a great deal of planning. Unlike the earlier Liberians, they did not trickle into their adopted homes as individuals or in small groups. Instead, the Everett people came together, as a group numbering over fifty, to Mercer County, Pennsylvania. The large number of people involved dictated a high degree of planning for all parties involved. For the whites in Albemarle County, Virginia, their aim was to remove any potential threats to the institution of slavery created by free persons of color. They needed to ensure that once relocated the Everett people would not threaten the continuation of slavery in Albemarle County. For the Everett people, planning included not only their acceptance of the conditions of the estate but also preparing for their departure from their homeland. Nearly all of the Everett people had family, and in some cases, their families lived on adjoining plantations and farms. That meant the Everett people had to prepare to say goodbye or make the necessary arrangements to purchase the freedom of their enslaved loved ones. Part of those negotiations also required them to set aside enough money to provide for their transportation out of the state as well.

${ }^{13}$ Samuel Shepherd, The Statutes at Large of Virginia, From October Session 1792, to December Session 1806, Inclusive, Vol. III, (New York: AMS Press Inc.), 252. 
Dr. Everett's nephew, Charles Everett, Jr. located land suitable for the relocation of his uncle's former chattel, and arranged for their transportation out of Virginia. Some of the Everett people succeeded in purchasing the freedom of their loved ones, while others like "Old" Joe Duke did not. The expense of their loved ones' freedom and the cost of their transportation out of Virginia must have seemed worthwhile to those who kept their families intact. The acquisition of land, the arrangement of transportation for nearly fifty people, and the purchase of loved ones took time and money. More than five years passed between the death of Charles Everett, Sr. and the day the Everett people boarded a train for Pennsylvania. After several days aboard trains, canal boats, and wagons the Everett refugees arrived in Mercer. ${ }^{14}$

Charles Everett, Jr. and the Everett people however, were not the only persons making plans in the relocation and resettlement. Once in Pennsylvania, the newly arrived refugees still needed additional assistance to maintain their freedom. Consequently, state lawmakers had also made plans; their efforts included formal recognition from the Pennsylvania legislature certifying that the Everett refugees were free persons of color. This recognition deterred and prevented the threat of kidnapping the refugees under the guise that they were escaped chattel hiding in Pennsylvania. Within Mercer County, local whites prepared for the arrival of the Everett refugees with mixed emotions. Some hoped their presence and subsequent successes would legitimize their anti-slavery sentiments. Other local whites however, viewed their arrival as a threat to the peace and security of their communities. Those locals opposed to the relocation of black refugees

\footnotetext{
14 “Emancipated Slaves," The National Era, 7 December 1854 from The Promulgator, Mercer, PA. Albemarle County Will Book \#23, 327; Albemarle County Courthouse, Charlottesville, VA.
} 
into their community sought avenues to defeat the resettlement efforts. Consequently, the Everett estate made careful preparations to prevent hostile whites from defrauding the Black refugees. Without the extensive planning by all parties involved in moving the Everett refugees into Mercer County, their freedom might have been short lived, if they achieved it at all.

Like their Liberian predecessors, the Everett refugees and their descendents did not stay in Mercer County. The circumstances of their emancipation and settlement in the county were not entirely of their own making. However, without their acceptance of the terms of the Everett estate, the later refugees would never have arrived in Mercer and might not have gained their freedom until the end of the Civil War. Although the Everett refugees were not active in the decision to resettle in Mercer County, as opposed to some other place, they nonetheless held high expectations for their new homes. ${ }^{15}$ Still, if the Everett refugees had been able to dictate their own terms for freedom and relocation, it seems plausible they might have plotted a course very different from white philanthropists. For the white trustees of the Everett estate and other abolitionists in Mercer County, the success in assisting Black refugees to transition from slavery to freedom rationalized their demands for abolition. To that end, the resettlement of the Everett refugees and others like them was an experiment for white abolitionists.

For trustees like William Clark and William Stephenson, the success of resettled Blacks in Mercer validated their abolitionist convictions. Clark edited the local abolitionist newspaper and was renowned for his reform-minded politics. Likewise,

\footnotetext{
${ }^{15}$ Rose Allen initially compared their new homes in Mercer County, Pennsylvania favorably with heaven. Hubert Rex Johnson, A History of the Neshannock Presbyterian Church, (Washington, D.C.: National Capital Presbytery Inc., 1925), 231.
} 
William Stephenson, a successful jurist in the county, also sponsored many reform measures. Stephenson was instrumental in bringing the water-cure facility and its abolitionist doctors to Mercer. ${ }^{16}$ Failure of the resettlement of the Everett refugees was little more than a setback to their personal ideals. Abolitionists, like Clark and Stephenson, risked little more than their pride in assisting the resettlement of the Everett people. The resettlement of emancipated blacks in Mercer County was a controlled situation in which Clark and Stephenson could test their abolitionist and racial ideologies. On many levels then, the concept of Pandenarium was an experiment for white philanthropists. Indeed, recent recollections of Pandenarium sometimes refer to it as an "experiment." ${ }^{17}$ Many whites believed that Blacks might squander not only their financial resources but also their freedom. At the same time, those same whites believed that Blacks and Black refugees still needed the guiding hide of white paternalism.

Only a few years prior to the arrival of the Everett refugees in Mercer County, Martin Delany of Allegheny City, Pennsylvania, noted generally that Blacks found themselves

\footnotetext{
${ }^{16}$ History of Mercer County, Pennsylvania. Its Past and Present., (Chicago: Brown, Runk and Co., Publishers, 1888), 237; "Obituary of Susan Clark," Indianapolis News, 17 July 1907. Hubert Rex Johnson, A History of the Neshannock Presbyterian Church, (Washington, D.C.: National Capital Presbytery Inc., 1925), 230; Letter from James Catlin to Frederick Douglass in the Frederick Douglass Paper, 3 June 1853.

${ }^{17}$ William and Jane Pease, "Organized Negro Communities: A North American Experiment," The Journal of Negro History, Vol. 47, No. 1 (January, 1962), 19 - 34; Melvin Patrick Ely, Israel on the Appomattox: A Southern Experiment in Black Freedom from the 1790s Through the Civil War, (New York: Alfred A. Knopf, 2004); Christina Greggs, "Pandenarium was a dream that turned into a nightmare," The Sharon Herald, 28 February 2000; Gail Habbyshaw, "Follow the Drinking Gourd: Walking Tour of Mercer's Historic Underground Railroad and Abolitionist Era Sites," Mercer County Historical Booklets, MCHS Booklet \#2 (Mercer, PA: Mercer County Historical Society, 2002), 17; Larissa Theodore, "PBS Documentary tells local Underground Railroad story," The Sharon Herald, 20 February 2003.
} 
occupying the very same position in relation to our Anti-Slavery friends, as we do in relation to the pro-slavery part of the community - a mere secondary, underling position, in all our relations to them, and anything more than this, is not a matter of course affair - it comes not by established anti-slavery custom or right, but like that which emanates from the pro-slavery portion of the community, by mere sufferance. ${ }^{18}$

Emancipated Blacks had their own notions of freedom and it did not necessarily mimic that of anti-slavery whites. Even well intentioned "experiments" in paternalism do not often end well for those subordinated. The fact that many of the Everett refugees felt compelled to move on after the Civil War demonstrated that the "almost heaven" of their initial experience in Mercer had dissipated. So long as slavery existed their ability to leave Mercer was severely limited, but the passage of the $13^{\text {th }}$ Amendment abolished chattel slavery in the United States and eliminated the threat that slaveholders might pursue Black refugees for financial gain. White paternalism shaped the departure of the Everett refugees from Virginia and subsequent resettlement in Pennsylvania; racial stereotyping resulting from chattel slavery in turn shaped the paternalism. Once abolished, the paternalism born of slavery ceased to hold sway over the Everett refugees and many chose to leave Mercer County.

James Duke was the first refugee to sell any of his lands, and he did so only three years after his arrival in Mercer. With the assistance of his court appointed trustee, William Stephenson, Duke sold his 22.5 acres in Springfield Township to John Black for the sum of $\$ 390 .{ }^{19}$ In 1860 , Wilson Nicholas followed suit and sold his landholdings in Mercer County. Nicholas acquired his land in 1857, later than the other Everett refugees,

\footnotetext{
${ }^{18}$ Martin Robison Delany, The Condition, Elevation, Emigration, and Destiny of the Colored People of the United States (Reprint Edition. Salem, New Hampshire: Ayer Company Publishers, Inc., 1988), 27.

${ }^{19}$ Mercer County Deed Book Q, Vol. 3, 151; Mercer County Recorders Office, Mercer County Courthouse, Mercer, Pennsylvania.
} 
but he quickly disposed of the land and moved in with George Duke and his family.

With the assistance of William Stephenson, Nicholas sold all 38 of his acres in Wilmington Township for the princely sum of $\$ 1300 .{ }^{20}$ Wilson Nicholas's age in 1860 , might offer some clue as to why he sold his land and moved in with the Duke family. Although not the oldest Everett refugee, Nicholas was nearly 70 years old when he moved in with the Dukes. In his advanced age Nicholas depended upon three things to maintain himself; his trustee William Stephenson, the profits from the sale of his land, and George Duke's household. Unfortunately for Nicholas, this last element had failed him by 1870 , as George Duke and his wife sold their lands in the county and moved away. ${ }^{21}$ Without land and without George Duke's assistance, Nicholas found himself in a precarious state. Despite the profits from his land, Wilson Nicholas called the County Alms House his home in 1870 and the census officially listed him as a pauper. ${ }^{22}$

George Duke's abrupt departure appears to be the culmination of several factors. In 1866, local authorities indicted Duke for selling alcohol without a license, two years later he sold his claims in the borough of Mercer. ${ }^{23}$ Duke sold his holdings to Carver Cozad for the sum of $\$ 1050$, a portion of which may have gone towards any outstanding

\footnotetext{
${ }^{20}$ Mercer County Deed Book K, Vol. 2, 323; Mercer County Recorders Office, Mercer County Courthouse, Mercer, Pennsylvania.

${ }^{21}$ George Duke and his wife sold their lands in two transactions the first of which transpired in 1865 and the second in 1868. Mercer County Deed Book R, Vol. 2, 69 and Mercer County Deed Book I, Vol. 3, 213; Mercer County Recorders Office, Mercer County Courthouse, Mercer, Pennsylvania.

${ }^{22}$ Schedule 1 - Free Inhabitants of Coolspring Township in the County of Mercer, State of Pennsylvania, Census Series M593, Roll 1373, 21.

23 "November Sessions, 1866," Mercer County Quarter Sessions Docket (August 1863 April 1869) Book 7, pp. 290 - 291; Mercer County Clerk of Courts Office, Mercer, PA.
} 
legal fees or fines. ${ }^{24}$ The attention his indictment brought most certainly reached the ears of whites hostile to the arrival of black refugees in Mercer, and perhaps those same whites trumpeted Duke's legal troubles enough to impact his blacksmithing business. The legal problems, which plagued Duke, might have prompted him to look for a home and business outside of Mercer County, but the end of the Civil War provided him with the opportunity to do so. Duke and his family need not fear slave-catchers any longer, and could move to any part of the nation they desired without reason to fear reenslavement. Likewise, his settlement with the Everett estate gave him freedom to move because it allowed him to sell his land to anyone he wished at anytime.

Although it remains unclear whether debts resulting from Duke's legal troubles contributed to the loss of his land, debt prompted the sale of Letitia Robertson's land in the county. Letitia died in October of 1859, and left her land holdings to her husband Jackson Robertson and sons in fee. Unfortunately, Jackson was unable to take possession of the land, a court appointed auditor found Letitia's debts sufficient to warrant the sale of her land claims to settle her estate. Charles Madden purchased the Robertson land and received title to the same in September 1862. Madden began at once to evict the Robertson's from the land and obtained orders from the justice of the peace supporting his claim to the land. Jackson Robertson appealed to the courts, he argued that Dr. Charles Everett willed the land to his wife as part of her share of the Everett estate and she in turn willed the land to him. Despite his appeals, the lower courts upheld Madden's claims. Undaunted, Robertson continued his appeals to the highest courts of

\footnotetext{
${ }^{24}$ Mercer County Deed Book I3, 213; Mercer County Recorders Office, Mercer County Courthouse, Mercer, PA.
} 
Pennsylvania, only to remain disappointed in their rulings. On September 20, 1863, Charles Madden took possession of the disputed land. ${ }^{25}$

Debt was not the only adversary of the Black refugees, for other Pandenarians age conspired against them. William Reeves was 70 years old in 1870, and, although he claimed farm laborer as his occupation, his own farm was apparently too much to take care of by himself; Reeves had children but none were older than the age of ten. By 1870, William Reeves moved his family in with John and Rose Allen. A year later, he sold his 17 acres to Wilson Swartz for $\$ 568 .^{26}$ That same year in 1871 , Reeves' halfbrother Henry Meyers also sold 17 acres immediately adjacent to Reeves' claim to Wilson Swartz. ${ }^{27}$ Reeves' decision to sell his land and move in with the Allens was a decision born of necessity. At 70, taking care of a farm was a daunting task, only compounded by his extremely young and large family. Reeves' wife, Elizabeth, was 40 years old, slightly more than half his age. Their four children ranged in age from one to nine years old. ${ }^{28}$ Their father's decision to sell his land denied them a stake in the Everett legacy but at the same time the proceeds of the land probably went a long way in providing for their care. For William and Elizabeth Reeves having land in 1870 was more a burden than a blessing for their family.

${ }^{25}$ Stewart et al., Appellants, v. Madden in James Monaghan, Pennsylvania State Reports, Vol. 153: Containing Cases Adjudged in the Supreme Court of Pennsylvania, (New York and Albany: Banks and Brothers Law Publishers, 1893), 446 - 447.

${ }^{26}$ Mercer County Deed Book C, Vol. 3, 509; Mercer County Recorders Office, Mercer County Courthouse, Mercer, PA.

${ }^{27}$ Mercer County Deed Book G, Vol. 3, 89; Mercer County Recorders Office, Mercer County Courthouse, Mercer, PA.

${ }^{28}$ Schedule 1 - Free Inhabitants of East Lackawannock Township in the County of Mercer, State of Pennsylvania, Census Series M593, Roll 1373, 65. 
Whatever their reasons for selling, by 1870 all of the Pandenarians could, if free from debt, make the decision to sell their lands without consulting an estate trustee. The trustees no longer held the final say over financial matters in the lives of the Black refugees and their families. In 1871, the Everett estate made its final payment to the refugees in Mercer County; John Allen, Jr. received the last of the financial legacy. ${ }^{29}$ The Everett estate settled with the majority of the Black refugees in 1860, and settled with the remaining refugees in 1869 and $1871 .{ }^{30}$ For the Everett refugees the Civil War provided the last stop on their road to freedom.

Because whites viewed resettlement efforts, like that of the Everett refugees, as an experiment, there was an implied sense of uncertainty. Although they might have had a hypothesis as to how the resettlement of Black refugees might turn out, as an experiment there were no guarantees; these experiments might succeed or they might not. There was however, some irony to these experiments; as long as whites perceived an uncertain outcome to the experiments, they provided aid. If, however, they believed that these communities were not experiments and therefore had an inevitable conclusion, there was no need to provide aid; no amount of aid, financially or socially would alter the outcome. Sociologist Egon Kunz found similar circumstances in the support and maintenance of refugees in general:

\footnotetext{
${ }^{29}$ Albemarle County Chancery Orders \#7 (1868 - 1872), 512; Albemarle County Courthouse, Charlottesville, VA.

${ }^{30}$ By 1860, Joe Duke, Nancy Bell, Tom Bell, Milly Bell, Windsor Duke, James Duke, George Lewis, Ed Watson, Willis Lewis, Mary Jane Lewis, Wilson Nicholas, and the estates of Susan Lewis, Jackson Bell, and Rachel Bell as well as Letitia Robertson and her children had all settled with the Everett estate. Albemarle County Chancery Orders \#6 (1860 - 1867), 52. In 1869, John Allen, Sr., Jackson Robertson, and William Rives settled with the Everett estate. Albemarle County Chancery Orders \#7 (1868 - 1872), 163 and 512; Albemarle County Courthouse, Charlottesville, VA.
} 
The re-settled refugee ceases to be a problem demanding solution. For the refugee administrator he becomes a closed case for whom solution has been found. ${ }^{31}$

As long as Black refugees remained unsettled, philanthropic whites still found need, and ways, to support them. Still, these relief efforts were largely financial in orientation. The accounts of Pandenarium as a village with ready-built houses, boxes of clothes, schools, and a church already provided, give some indication of what whites in both Mercer and Albemarle counties viewed as adequate support. ${ }^{32}$ At the same time, these prevailing stories also lead contemporary viewers to perceive Pandenarium a failure.

Therein rests the problem of the historiography of Black settlement efforts. Historians have persistently attempted to qualify Black settlements as either a success or failure. These rigid categories of interpretation have only reasserted the beliefs of the white philanthropists who originally assisted these Black settlements--that the settlements were experiments. Over the years historians have attempted to write a conclusion for them. For Blacks these experiments frequently left them only two options; either they needed to conform entirely to the paternalism of the experiment or they had to chart their own course irrespective of the wishes of their white anti-slavery friends. Charting their own course usually branded Black settlements as less than successful because it defied the prevailing paternalism. Conformity, on the other hand, met with mixed results particularly in Mercer County. Some refugees adapted quite well and succeeded in

${ }^{31}$ E.F. Kunz, "The Refugee in Flight: Kinetic Models and Forms of Displacement," International Migration Review, Vol. 7, No.2 (Summer, 1973), 128.

${ }^{32}$ Christina Greggs, "Pandenarium was a dream that turned into a nightmare," The Sharon Herald, 28 February 2000; Gail Habbyshaw, "Follow the Drinking Gourd: Walking Tour of Mercer's Historic Underground Railroad and Abolitionist Era Sites," Mercer County Historical Booklets, MCHS Booklet \#2 (Mercer, PA: Mercer County Historical Society, 2002), 17; Larissa Theodore, "PBS Documentary tells local Underground Railroad story,” The Sharon Herald, 20 February 2003. 
establishing themselves financially. Others, however, struggled from the moment they arrived. So just as whites in the nineteenth century judged the settlement efforts of Black refugees as successes or failures, historians in the twentieth and twenty-first centuries continue to judge them by the same criteria..

Sociologists, in contrast, have demonstrated the complexity of refugee resettlement. They describe refugee status as a prolonged process that in some cases takes several generations to play out. ${ }^{33}$ Egon Kunz's model for kinetic movements of refugees shows that even in flight there are multiple steps. Stephen Keller, another sociologist, built upon Kunz's work and proposed there are nine stages to the refugee experience, with only the first three stages preoccupied with flight. ${ }^{34}$ For the Liberians the threat of re-enslavement limited the assimilation process. They intentionally limited their social contacts within Mercer County to protect themselves from whites and Blacks who sought to betray their location and freedom. Even for the Everett refugees, the process of social assimilation proceeded at a slow pace. In both cases, however, the continued perception of Black settlements as an experiment that might fail and the racial stereotypes associated with those perceptions inhibited the complete assimilation of Black refugees into the broader community. Failure to assimilate might contribute to the demise of a spatial community, but unless historians account for the original aims of the refugees themselves, it is unfair to broadly characterize their settlements in this way.

\footnotetext{
${ }^{33}$ Barry Stein, "The Refugee Experience: Defining the Parameters of a Field Study," Inernational Migration Review, Vol. 15, No. 1/2, Refugees Today. (Spring - Summer, 1981), 325.

${ }^{34}$ Stephen Keller, Uprooting and Social Change: The Role of Refugees in Development, (New Delhi, India: Manohar Book Service, 1975); Barry Stein, "The Refugee Experience: Defining the Parameters of a Field Study," International Migration Review, Vol. 15, No. 1/2, Refugees Today. (Spring - Summer, 1981), 321.
} 
Melvin Ely's work on manumitted Blacks in south-central Virginia stops short of characterizing the Black settlement at Israel Hill in Prince Edward County as a success or failure. However, in cautioning other historians from generalizing the South as a racist monolith, Ely implies a measure of success for Blacks at Israel Hill. The Black community at Israel Hill, unlike those in Mercer County, Pennsylvania, did not face the process of assimilation. While the Blacks at Israel Hill and the Everett refugees all gained their freedom from the posthumous wishes of slaveholders, the slave system treated them differently. The Everett refugees were forcibly removed from the region of their birth and from kin owned by others; at Israel Hill the slaveholders in Prince Edward County bequeathed their former chattel land from their estate. Whether considered a success or a failure, the free Black community at Israel Hill was not a refugee community. Consequently, its members did not share the refugee experience of the Liberian or Everett people. ${ }^{35}$

Like Ely, Willie Lee Rose studied the social developments and upheavals wrought by the emancipation of Blacks in the Seas Islands of South Carolina. The social changes that emancipators labeled the "Port Royal experiment" attempted to address the question of what to do with large numbers of emancipated Blacks. Just months after the onset of the Civil War, federal troops invaded and secured the area around Beaufort, South Carolina. Rose described the ensuing social interactions between emancipated Blacks and northern whites as "a dress rehearsal for Reconstruction acted out on the stage neatly

\footnotetext{
${ }^{35}$ Melvin Patrick Ely, Israel on the Appomattox: A Southern Experiment in Black Freedom from the 1790s Through the Civil War, (New York: Alfred A. Knopf, 2004).
} 
defined by the Sea Islands of South Carolina." ${ }^{36}$ Although characterized as an experiment, the freedpeople of the Sea Islands did not face the task of assimilating into a new community, leaving behind both friends and family. Like those in Israel Hill, the Blacks in Port Royal never left their homes. Free Blacks at Port Royal struggled to redefine themselves socially as their plans for their post-slavery lives differed from the paternalistic plans of white missionaries, who sought to create the preferred model for the transition from slavery to freedom.

North of the Mason and Dixon Line, the social experiments that were black settlements differed from those of Israel Hill and Port Royal. Like Melvin Ely, historian Leon Litwack, in North of Slavery, cautioned other historians not to define the North as an anti-slavery, egalitarian monolith. Race relations and racial prejudice differed little from that found in the South; whites both North and South subscribed to the inferiority of blacks. Despite anti-slavery sentiments, some whites in the North looked to remove blacks from immediate contact with their communities, instead choosing to encourage relocation to more rural settings. Litwack discussed, albeit briefly, rural resettlement efforts in the North. He concluded that such projects "failed miserably" because northern urban blacks were disinterested in "the virtues of agrarian life." ${ }^{, 37}$ Many of these urban blacks, who were not so recently arrived, no doubt understood the paternalism of resettlement as defined by whites. Resettlement only segregated them from white communities of the North and reduced them to subservient status--good enough to be freed but not good enough to settle in the same town.

\footnotetext{
${ }^{36}$ Willie Lee Rose, Rehearsal for Reconstruction: The Port Royal Experiment (Indianapolis: Bobbs-Merrill Company, 1964), xi.

${ }^{37}$ Leon Litwack, North of Slavery: The Negro in the Free States, $1790-1860$ (The University of Chicago Press: Chicago and London; 1961), p. 176-177.
} 
William and Jane Pease also offered an interpretation of the rural resettlement of blacks in their work Black Utopia. In both North and South, reformers sought to segregate blacks into their own communities and provide agrarian and mechanical training so that blacks might sustain their settlements apart from whites. The inherent paternalism of their efforts reinforced white superiority. Instead of liberating former slaves, white philanthropy prepared blacks for a subservient role in American society. The Peases concluded that the failure of black settlements was the culmination of their spatial segregation. Because the architects of black settlements failed to confront integration, the spatial communities failed to remain viable for blacks socially and economically. Consequently, blacks abandoned the rural settlements in the North. Success or failure then, as defined by the Peases, depended upon the continued or prolonged spatial existence of the black settlements. Once they were gone from the physical landscape, the individual settlement efforts failed. ${ }^{38}$

While the Peases were not entirely off the mark in their assessment that black resettlement efforts failed due to an inability to overcome racial segregation, they still predicated their assertion on the spatial continuation of black communities. Their conclusions fail to account for the other obstacles, outside of race, of the refugee experience. Their conclusions assume the persistence and constancy of racism of northern white communities.

Decades after the Peases study of black communal experiments, Nikki Taylor argued that, those who reduce black settlements' "existence to a label of 'failure' would

\footnotetext{
${ }^{38}$ William H. Pease and Jane Pease, Black Utopia: Negro Communal Experiments in America, (Madison: The State Historical Society of Wisconsin, 1963), 160 - 163.
} 
do well to revisit the goals of the original settlers." ${ }^{39}$ This approach was a marked difference from the earlier attempts to define black settlement efforts as successes or failures, based upon the aims of white philanthropists and/or architects. Her argument also calls for a reconsideration of the existing view that the continued existence of black settlements is the criteria for determining success or failure. ${ }^{40}$

Like Taylor, historian Harvey Amani Whitfield urges caution in studying black settlement efforts. Whitfield has argued that too many historians rely heavily upon the documentary evidence provided by whites. ${ }^{41}$ It goes, almost without saying, that using documentary evidence from whites provides a biased view of these settlements. But because whites viewed these efforts as experiments and were unsure whether blacks could actually develop and thrive financially and socially in American society, racial stereotypes taint the documentary evidence and threaten to skew contemporary studies with the same. Without some documentary evidence from the black refugees themselves, scholars cannot understand the motivations of the refugees. This dearth of evidence frequently denies them agency. Without looking at the settlement efforts from the perspective of black refugees, they are consigned to "caricature, ... miserable wretches constantly in search of government or private assistance." ${ }^{42}$

Although both settlements in Mercer County benefitted from assistance, from government and private individuals, the refugees of both sought self-assertion and self-

\footnotetext{
${ }^{39}$ Nikki Taylor, "Reconsidering the 'Forced' Exodus of 1829: Free Black Emigration from Cincinnati, Ohio to Wilberforce, Canada." The Journal of African American History, Vol. 87, (Summer, 2002), 297.

${ }^{40}$ Ibid., $283-302$.

${ }^{41}$ Harvey Amani Whitfield, “'We Can Do As We Like Here': An Analysis of Self Assertion and Agency Among Black Refugees in Halifax, Nova Scotia, 1813 - 1821," Acadiensis, XXXII, No. 1 (Autumn, 2002), 30.

${ }^{42}$ Ibid., 49.
} 
determination. Still the picture that Whitfield presents of black refugees in Nova Scotia was that they were not hapless victims and were instead forerunners of the black consciousness movement. In Canada, though, black refugees benefitted from one principle difference separating them from the black refugees in Mercer County; they did not fear pursuit, recapture, and resale into slavery. The earlier refugees of Liberia felt the threat of re-enslavement most keenly. Their settlement depended most upon their constant vigilance, not financial support. That same vigilance, however, also served as an obstacle to their assimilation into the broader community. Unlike the refugees of Whitfield's study, they could not do entirely as they might like. ${ }^{43}$

Neither the Liberian nor Everett refugees who came to Mercer County in the $19^{\text {th }}$ century stayed beyond a few generations. It is unfair to categorize their respective settlements in the county as failures, simply because they and their descendents failed to stay in Mercer in perpetuity. The Fugitive Slave Act of 1850 nullified any refuge the county initially offered the Liberians. The federal legislation threatened their liberty, consequently the law pushed Liberians into Canada beyond the reach of slave-catchers. The Everett refugees settled in Mercer County in spite of any desires they had to relocate elsewhere. Their settlement in Mercer tied them to a place. There, state and local authorities legitimized their claims to freedom but in doing so limited their claims to freedom geographically. ${ }^{44}$ If the Everett refugees moved away from Mercer County prior

\footnotetext{
${ }^{43}$ Confronted by white trespassers on their farm in Canada, a family of black refugees "defiantly informed the trespassers that the land was 'our own, we are not in the U. States, and we can do as we like here." Ibid., 29.

${ }^{44}$ Laws of the General Assembly of Pennsylvania, of the Session of 1855. No. 324, An Act to Authorize and Empower the Court of Common Pleas of Mercer County to Legitimate Certain Persons who were Emancipated by the Last Will and Testament of Dr. C.D. Everett, late of Albemarle County, Virginia.
} 
to 1860 , they risked their respective claims to the Everett estate. The estate held the lands in Mercer in trust for the refugees, and although they could pass the land on to their descendents, the trust limited their abilities to sell the land outright.

Even if the Everett people were willing to relinquish their claims to land in Mercer and desired to move elsewhere, such a move was fraught with dangers and uncertainties. Carol Wilson's research on the kidnapping of free blacks documents the tenuous nature of black freedom in the early $19^{\text {th }}$ century. She points out that there was no shortage of anti-kidnapping legislation from state to state; even most southern states passed such legislation. The problem however, was not necessarily in the legislation, but its sporadic and uneven enforcement. No federal anti-kidnapping legislation passed Congress until 1866 , by then slavery was illegal in the United States. ${ }^{45}$ This meant that curtailing kidnapping was a state issue even as the recapture of "fugitive slaves" was a federal one. As noted previously, freedom for blacks in American meant very little, legally, after the passage of the Fugitive Slave Act of 1850 and the Dred Scott decision in 1857. Even before the passage of the 1850 act abolitionists noted that:

Where a traffic in slaves is thus actively carried on and sanctioned by existing laws, those coloured persons who are legally free, must necessarily hold their freedom by a very precarious tenure, particularly where every person tinged with an African die (sic) is presumed to be a slave, unless proven to be free. ${ }^{46}$

Although, "proven to be free," in 1855 by An Act ... to Legitimate Certain Persons who were Emancipated by the Last Will and Testament of Dr. C.D. Everett, this proven only provided safety within specific locale. The strange tale of Frank Jackson's kidnapping

${ }^{45}$ Carol Wilson, Freedom At Risk: The Kidnapping of Free Blacks in America, 1780 1865, (Lexington, KY: The University of Kentucky Press, 1994), 67 - 72.

${ }^{46}$ Enoch Lewis, ed. The African Observer, (Philadelphia: Enoch Lewis, 1828), 103. 
and his subsequent rescue in 1840 bore witness to the potential dangers confronting Mercer's free black residents who ventured too far from the county's relative safety. ${ }^{47}$

There was another advantage to the cultural geography of Mercer County for the Everett people. As a group they were less susceptible to kidnappers, and in the event that someone might entertain thoughts of kidnapping one of them they could depend upon each other for defense; there was safety in numbers. Historian Gary Nash noted in his study of free blacks in Philadelphia "that the only secure foundation upon which to fashion their lives was ... relying on their own resources rather than on white benevolence.” ${ }^{48}$ With the noted exception of John Mitchell and the Liberian settlement in Mercer County, blacks understood they could depend upon each other more readily than they could neighboring whites. ${ }^{49}$ The early black refugees who arrived in Mercer County looked to Richard Travis and his Liberian community for guidance and support. Likewise, the Everett people looked to one another for support. Their readiness to take in the children of deceased family members, and even children apparently unrelated, demonstrates their understanding of self-reliance. Collectively, they worked together to ease the transition from refugee to full citizen.

The end of the Civil War changed the parameters of the Everett refugees' exile. With slavery abolished, the presumption that Black refugees were enslaved first and free persons of color second no longer held the Everett refugees hostage. For the Everett

47 "The Kidnapping and Recovery of Frank Jackson; Two Underground Stations in New Castle, Lawrence County," New Castle Daily News, 5 March 1897.

${ }^{48}$ Gary B. Nash. Forging Freedom: The Foundation of Philadelphia's Black

Community, 1720 - 1840, (Cambridge, MA: Harvard University Press, 1988), 5.

${ }^{49}$ Mitchell betrayed several members of the Liberian settlement and alerted slave hunters of the presence of black refugees along Sandy Lake in Mercer County. Wesley Hogue to Wilbur Siebert, undated, Wilbur H. Siebert Collection, Microfilm Edition (MIC 192, Roll 13) Ohio Historical Society, Columbus. 
refugees, the end of the war and the subsequent end to chattel slavery afforded them a degree of self-determination previously denied. The threat of re-enslavement no longer bound them to Mercer; they could and often did choose their own locations to resettle. It is hard to argue that increased access to self-determination qualified as a failure. The Everett refugees did not fail in their endeavors in Mercer any more than the earlier Liberians did. Circumstances altered the conditions surrounding their resettlement, and thus Mercer County simply outlived its usefulness for the Everett refugees.

As experiments, it is equally faulty to qualify the refugee settlement efforts in Mercer County failures. These experiments in black settlements begged the question: were blacks were capable of equality? To that end, the Everett refugees' inability to make decisions for their own well-being contrary to white trustees reduced them to inferiors. Tied to the lands held in trust for them, the Everett refugees were more susceptible to economic pitfalls resulting from downturns in the local economy. For the Liberian refugees the limitations on equality and opportunity were even more striking. Because the Liberians took their own liberty through escape from bondage, they lived in almost constant fear that slave-catchers might capture them at any moment and return them to bondage. Liberians lived a segregated existence in order to preserve their freedom. Whites in Mercer did not suffer this same fear of enslavement, and some profited from this fear by turning in their black neighbors in Liberia. The Liberian refugees took flight for Canada after the passage of the Fugitive Slave Act of 1850 precisely because they had no legal status except as runaway slaves anywhere in the United States. As experiments, the settling of Liberians and Everett refugees in Mercer were failures so long as they continued, and not because the refugees moved away. 
William and Jane Pease were not wrong in their assessment that the social experimentation that led to communal black resettlement efforts, failed to confront the challenge of integration, although the Everett refugees were not entirely segregated from their white neighbors. However, the refugee resettlement efforts in Mercer County were neither successes nor failures because they failed to achieve integration and equality. Integration evaded the United States for nearly a century after the Civil War. Segregation and racism did not determine or dictate the degree of assimilation of Liberians and Everett people into Mercer County; they were a part of the larger refugee experience. As long as historians persist in evaluating the success rate of black resettlement in the nineteenth century by their prolonged spatial existence they continue to ignore the refugee experience of blacks. Defining black resettlement efforts like those in Mercer County as refugee experiences, allows historians to use sociological models to better understand and interpret the actions of black settlers, rather than qualify them as successes or failures.

There is a tendency to dwell on refugee success stories which are not representative of the experiences of the group ... In reality, lives torn apart are not easily repaired. The refugee pays a high price for flight. Remember, though, that the refugee fled for safety and freedom not for economic or social values and opportunities. ${ }^{50}$

${ }^{50}$ Barry Stein, "The Refugee Experience: Defining the Parameters of a Field Study," Inernational Migration Review, Vol. 15, No. 1/2, Refugees Today. (Spring - Summer, 1981), 328. 


\section{SELECTED BIBLIOGRAPHY}

\section{Published Works}

Acts and Resolutions of the General Assembly of the Commonwealth of Virginia, 1816 - 1817, No. 1. Richmond: Thomas Ritchie, 1817.

Aptheker, Herbert. American Negro Slave Revolts. New York: Columbia University Press, 1943.

, ed. A Documentary History of the Negro People in the United States. New York: The Citadel Press, 1951.

American Colonization Society. The African Repository and Colonial Journal, Vol. XIII. Washington: James Dunn, 1837.

American Colonization Society. Fortieth Annual Report of the American Colonization Society, with the Proceedings of the Board of Directors and of the Society. Washington: C. Alexander, Printer, 1857.

Baily, Francis. Journal of a Tour in Unsettled Parts of North America in 1796 and 1797. London, 1856.

Bland, Jr., Sterling Lecater, ed. African American Slave Narratives, Vol. II. Westport, Connecticut: Greenwood Press, 2001.

Blassingame, John W., ed. Slave Testimony: Two Centuries of Letters, Speeches, Interviews and Autobiographies. Lousiana State University Press: Baton Rouge, 1977.

Cairnes, John E. The Slave Power, Its Character, Career, and Probable Designs. Reprint edition; New York: Augustus M. Kelley Publishers, 1968.

Carroll, J. C. Slave Insurrections in the United States, 1800 - 1865. New York: Negro Universities Press, 1938.

Catterall, Helen C. Judicial Cases Concerning American Slavery and the Negro, Vol. 1. Washington, D.C.: Carnegie Institute of Washington, D.C., 1926.

Darling, Katie. Interview by Unknown, 2 August 1937, in The American Slave: A Composite Autobiography, Vol. 6, George P. Rawick, ed., 1047 - 1051. Westport, CT: Greenwood Press, 1979.

Davis, Richard Beale. Francis Walker Gilmer: Life and Learning in Jefferson's Virginia. Richmond, VA: The Dietz Press, 1939. 
Delany, Martin Robison. The Condition, Elevation, Emigration and Destiny of the Colored People of the United States. Reprint Edition; Salem, New Hampshire: Ayer Company Publishers, 1988.

Drew, Benjamin. A North-Side View of Slavery. The Refugee: or the Narratives of Fugitive Slaves in Canada. Boston: John P. Jewett and Company, 1856.

Durin, Eric. Slavery and the Peculiar Solution: A History of the American Colonization Society. Gainesville: University of Florida Press, 2005.

Edwards, Paul, ed. Equiano's Travels. New York: Praeger, 1967.

Ely, Melvin Patrick. Israel on the Appomattox: A Southern Experiment in Black Freedom from the 1790s Through the Civil War. New York: Alfred A. Knopf, 2004.

Everett, Robert Louis. The Everetts of Albemarle County Virginia. Riverside, CA: Canyon Crest Printing, 1992.

Foner, Eric. The Story of American Freedom. New York: W.W. Norton and Company, 1998.

Ford, Paul Leicester, ed. The Works of Thomas Jefferson, Vol. 12. New York and London: G.P. Putnam's Sons, $1904-05$.

Freehling, Alison Goodyear. Drift Toward Dissolution. Baton Rouge: Louisiana State University Press, 1982.

Genovese, Eugene D. Roll, Jordan, Roll: The World the Slaves Made. New York: Vintage Books, 1976.

Green, William. Narrative Events in the Life of William Green, (Formerly a Slave) Written by Himself. Springfield: L.M. Guernsey, Book, Job, and Card Printer, 1853.

Habbyshaw, Gail and Rachel Darby, ed. Follow the Drinking Gourd: Walking Tour of Mercer's Historic Underground Railroad and Abolitionist Era Sites. Mercer County Historical Booklets, MCHS Booklet \#2; Mercer, Pennsylvania: Mercer County Historical Society, 2002.

Higginson, Thomas Wentworth. Travellers and Outlaws; Episodes in American History. Boston: Lee and Shepherd Publishers, 1889.

History of Mercer County. Chicago: Brown, Runk, and Company Publishers, 1888. 
History of Mercer County Pennsylvania. Philadelphia: L.H. Everts and Company, 1877.

Hodge, Ruth, ed. African American Resources at the Pennsylvania State Archives. Harrisburg: Pennsylvania Historical and Museum Commission, 2000.

Johnson, Hubert Rex. A History of the Neshannock Presbyterian Church. Washington, D.C.: National Capital Presbytery Inc., 1925.

Journal of the Senate of the Commonwealth of Pennsylvania, Vol. 1. Harrisburg: Henry Welsh, $1831-1832$.

Keller, Stephen. Uprooting and Social Change: The Role of Refugees in Development. New Delhi, India: Manohar Book Service, 1975.

Kolchin, Peter. American Slavery, 1619 - 1877. New York: Hill and Wang, 2003.

Lane, Lunsford. The Narrative of Lunsford Lane, Formerly of Raleigh, N.C.; Embracing an Account of his Early Life, the Redemption by Purchase of Himself and Family From Slavery, and His Banishment from the Place of His Birth for the Crime of Wearing a Colored Skin, Third Edition. Boston: Published by Himself, 1845.

Lewis, Enoch, ed. The African Observer. Philadelphia: Enoch Lewis, 1828.

Life and Letters of Joseph Story, Associate Justice of the Supreme Court of the United States, and Dane Professor of Law at Harvard University, Vol. II. Boston: Charles C. Little and James Brown, 1851.

Litwack, Leon. North of Slavery: The Negro in the Free States, 1790 - 1860. The Chicago and London: University of Chicago Press, 1961.

Marsh, Luther Rawson, ed. The Writings and Speeches of Alvan Stewart. New York: A. B. Burdick, 1860.

Maxwell, W. J. General Alumni Catalogue of the University of Pennsylvania. The Alumni Association of the University of Pennsylvania, 1922.

Mead, Edward C. Historic Homes of the Southwest Mountains of Virginia. J.B. Lippincott Co., 1898.

"Minutes from the case of Commonwealth v. Nathanial Jennison," in Proceedings of the Massachusetts Historical Society, Vol. 1873 - 1875, 292 - 295. Boston: Massachusetts Historical Society, 1875.

Monaghan, James. Pennsylvania State Reports, Vol. 153: Containing Cases Adjudged in the Supreme Court of Pennsylvania. New York and Albany: Banks and Brothers Law Publishers, 1893. 
Nash, Gary. Forging Freedom: The Formation of Philadelphia's Black Community, 1720 - 1840. Harvard University Press: Cambridge, MA, 1988.

Newman, Richard S. The Transformation of American Abolitionism: Fighting Slavery in the Early Republic. Chapel Hill: University of North Carolina Press, 2002.

Pease, William and Jane. Black Utopia: Negro Communal Experiments in America. Madison, WI: The State Historical Society of Wisconsin, 1963.

Pennington, James W.C. The Fugitive Blacksmith; or Events in the History of James W.C. Pennington, Pastor of a Presbyterian Church, New York, Formerly a Slave in the State of Maryland, United States. Self Published, 1849.

Porter, Kenneth W. The Black Seminoles. Gainesville: The University of Florida Press, 1996.

Proceedings of the Pennsylvania Convention, Assembled to Organize A State Anti -Slavery Society, at Harrisburg. Philadelphia: Merrihew and Gunn, 1837.

Reeher, Lillian. Wolf Creek Legacy II. Mercer, Pennsylvania: Mercer County Historical Society, undated.

Rose, Willie Lee. Rehearsal for Reconstruction: The Port Royal Experiment. Indianapolis: Bobbs-Merrill Company, 1964.

Russell, John H. The Free Negro in Virginia, 1619 - 1865. Reprint Edition; New York: Dover Publications, 1969.

Samuel Shepherd, The Statutes at Large of Virginia, From October Session 1792, to December Session 1806, Inclusive, Vol. III. Reprint Edition; New York: AMS Press Inc., 1970.

Scott, James. Weapons of the Weak. New Haven: Yale University Press, 1985.

Schwarz, Philip J. Twice Condemned: Slaves and the Criminal Laws of Virginia, 1705 - 1865. Union, NJ: The Lawbook Exhange, Ltd., 1998.

Seaman, Catherine Coleman. A History of Southern Rockfish Families and Old Houses Lovington, VA: Nelson County Historical Society, 1990.

Sherwood, Henry Noble. "The Settlement of the John Randolph Slaves in Ohio," in Proceedings From the Mississippi Valley Historical Association, 39 - 59. Mississippi Valley Historical Society, 1912.

Slaughter, Philip. The Virginian History of African Colonization. Richmond, 1855. 
Statistical View of the United States, Embracing Its Territory, Population - White, Free Colored, and Slave - Moral and Social Condition, Industry, Property, and Revenue; the Detailed Statistics of Cities, Towns and Counties; Being a Compendium of the Seventh Census. Washington: Beverly Tucker, 1854.

Staudenraus, Philip. The African Colonization Movement, 1816-1865. New York: Columbia University Press, 1961.

Stephenson, Clarence D. Indiana County $175^{\text {th }}$ Anniversary History, Vol. IV. Indiana, PA: A.G. Halldin Publishing, 1983.

Steward, Austin. Twenty Two Years a Slave, and Forty Years a Freeman; Embracing a Correspondence of Several Years while President of Wilberforce Colony, London, Canada West. Chapel Hill, NC: Electronic edition, 1997. http://docsouth.unc.edu/fpn/steward/steward.html.

Story, Joseph. Commentaries on the Constitution of the United States, Vol. III. Boston: Hillard Gray and Company, 1833; reprint edition New York: De Capo Press, 1970.

Sydor, Charles S. The Development of Southern Sectionalism, 1819 - 1848. Baton Rouge, Louisiana State University Press, 1948.

The Federalist Papers. Cutchogue, NY: Buccaneer Books, Inc., 1992.

Tragle, Henry I. The Southampton Revolt of 1831: A Compilation of Source Material. Amherst: University of Massachusetts Press, 1971.

Tucker, St. George. A Dissertation on Slavery with a Proposal for the Gradual Emancipation of It, in the State of Virginia. Reprint Edition; Philadelphia: Matthew Carey Publisher, 1861.

United Nations Refugee Convention, Art. 1A. 1951.

Van Sertima, Ivan. They Came Before Columbus: The African Presence in Ancient America. Reprint Edition; New York: Random House, Inc., 2003.

Wilson, Carol. Freedom At Risk: The Kidnapping of Free Blacks in America, 17801865. Lexington, KY: The University of Kentucky Press, 1994.

Winch, Julie. Philadelphia's Black Elite: Activism, Accommodation, and the Struggle for Autonomy, 1787 - 1848. Philadelphia: Temple University Press, 1988.

Winks, Robin. The Blacks in Canada: A History. New Haven: Yale University Press, 1971. 


\section{Unpublished Works}

Boguess, Abel. Interview by Wilbur Siebert, 9 August 1892. Wilbur H. Siebert Collection, Microfilm Edition (MIC 192, Roll 13) Ohio Historical Society, Columbus.

Clark, William F., Jr. "Diary.” 1862. Historical Society of Western Pennsylvania; Pittsburgh, PA.

Gray, Amy and Susan Elliot, "Refugee Resettlement Project 'Refugee Voices': Literature Review," Wellington: Department of Labour, New Zealand Immigration Service, 2001.

Hall, Roland Barksdale. "People in Search of Opportunity: The African American Experience in Mercer County, Pennsylvania, A History and Guide," Penn State University: Shenango Valley Campus.

MacFayden, Joshua. "Following Flax Through History and Rural Space," Unpublished Paper presented at GIS Day at the University of Guelph, 4 November 2004.

. "Rural Adaptations: The Perine Flax and Lumber Mills in Ontario,1854 - 1871," Unpublished Paper presented at the Canadian Historical Association, Annual Meeting, 30 May 2005.

Mitchell, Robert T. "Biography of Dr. Robert and Jane C. Mitchell," Undated. Wilbur H. Siebert Collection, Microfilm Edition (MIC 192, Roll 13) Ohio Historical Society, Columbus.

Myers, Robert L. and Louis J. Meinke. "Buckwheat: A Multi-Purpose, Short Season Alternative," University of Missouri Extension, April 1994.

Polk, Joseph. Interview by William Hunter, 25 May 1946. "Negro Settlement," William Hunter Collection, Mercer County Historical Society, Mercer, PA.

Son, "Wesley Hogue," Wilbur H. Siebert Collection, Microfilm Edition (MIC 192, Roll 13), Ohio Historical Society, Columbus.

White, Joseph. "Some Reminiscences of Slavery Times," New Castle, PA, 1891. Wilbur H. Siebert Collection, Microfilm Edition (MIC 192, Roll 13), Ohio Historical Society, Columbus. 


\section{Periodicals}

Barghouthi, Mureed. "Songs For a Country No Longer Known," Journal of Palestine Studies, 27/2, 1998, 59.

Bauer, Raymond A. and Alice H. Bauer. "Day to Day Resistance to Slavery," Journal of Negro History, XXVII, October, 1942, 388.

Burke, Joseph. "What Did the Prigg Decision Really Decide?" Pennsylvania Magazine of History and Biography, Vol. XCII, 1969, 73.

Cromwell, John W. “The Aftermath of Nat Turner's Insurrection,” Journal of Negro History, Vol. 5, No. 2, April 1920, 208.

Finkelman, Paul. "The Kidnapping of John Davis and the Adoption of the Fugitive Slave Law of 1793," The Journal of Southern History, Volume 56, No. 3, August, 1990, 397.

. "Prigg v. Pennsylvania: Understanding Justice Story's Nationalism," The Journal of Supreme Court History, Vol. 2, 1997, 51.

- "Prigg v. Pennsylvania and Northern Courts: Anti-Slavery Use of a Pro-Slavery Decision," Civil War History, March 1979, 5.

Jackson, Luther Porter. "Manumission in Certain Virginia Cities," The Journal of Negro History, Vol. 15, No. 3, July 1930, 278.

Kunz, Egon F. "The Refugee in Flight: Kinetic Models and Forms of Displacement," International Migration Review, Vol. 7, No. 2, Summer 1973, 125.

- "Exile and Resettlement: Refugee Theory" International Migration Review Vol. 15, No. 1, Refugees Today, Spring - Summer 1981, 42.

Landon, Fred. "Agriculture Among the Negro Refugees in Upper Canada," The Journal of Negro History, Vol. 21, No. 3, July 1936, 304.

Lapansky, Emma Jones. “' Since They Got Those Separate Churches': Afro-Americans in Jacksonian Philadelphia," American Quarterly, Vol. 32, No. 1, Spring 1980, 54.

Mason, William. "Romances and Realities of the Underground Railroad," Johnson's Lake Shore Home Magazine, Volume III, No. 8, August 1887.

Mathias, Frank F. "John Randolph's Freedmen: The Thwarting of a Will," The Journal of Southern History, Vol. 39, No. 2, May 1973, 263. 
McGroarty, William Buckner. "Exploration in Mass Emancipation," William and Mary Quarterly Historical Magazine, $2^{\text {nd }}$ Ser., Vol. 21, No. 3. July 1941, 208.

Pease, William and Jane Pease. "Organized Negro Communities: A North American Experiment," The Journal of Negro History, Vol. 47, No. 1, January 1962, 19.

Pennypacker, Samuel. "The Settlement of Germantown and the Causes Which Led to It," The Pennsylvania Magazine of History and Biography, Vol. IV, 1880, 1.

Powell, C. A.; B.T. Kavanaugh; David Christy. "Transplanting Free Negroes to Ohio from 1815 to 1858," The Journal of Negro History, Vol. 1, No. 3. June 1916, 303.

Russell, Marion J. "American Slave Discontent in Records of the High Courts," The Journal of Negro History, Vol. 31, No. 4, October 1946, 411.

Scherr, Arthur. "Governor James Monroe and the Southampton Resistance of 1799," The Historian, Spring 1999, 557.

Schneeburg, Norman. "The Medical History of Thomas Jefferson (1743 - 1826)," Journal of Medical Biography, Volume 16, No.2, 2008, 118.

Simpson, Craig. "Political Compromise and the Protection of Slavery: Henry A. Wise and the Virginia Constitutional Convention of 1850 - 1851," The Virginia Magazine of History and Biography, Vol. 83, No. 4, October 1975, 387.

Smith, Eric Ledell. "The End of Black Voting Rights in Pennsylvania: African Americans and the Pennsylvania Constitutional Convention of 1837 - 1838," Pennsylvania History, 65, Summer 1998.

Stein, Barry. "The Refugee Experience: Defining the Parameters of a Field Study" International Migration Review, Vol. 15, No. 1/2, Refugees Today, Spring Summer 1981, 320.

Tang, Joyce. "Enslaved African Rebellions in Virginia," Journal of Black Studies, Vol. 27, No. 5, May1995, 598.

Taylor, Nikki. "Reconsidering the 'Forced' Exodus of 1829: Free Black Emigration from Cincinnati, Ohio to Wilberforce, Canada," The Journal of African American History, Vol. 87, Summer 2002, 283.

Thompson, Thomas Marshall. "National Newspaper and Legislative Reactions to Louisiana's Deslondes Slave Revolt of 1811," Louisiana History: The Journal of the Louisiana Historical Association, Vol. 33, No. 1, Winter 1992, 5. 
White, Deborah Gray. "Female Slaves: Sex Roles and Status in the Antebellum Plantation South,” Journal of Family History, Vol. 8, Fall 1983, 248.

Whitfield, Harvey Amani “ 'We Can Do As We Like Here' : An Analysis of Self Assertion and Agency Among Black Refugees in Halifax, Nova Scotia, 1813 - 1821,” Acadiensis, XXXII, 1, Autumn 2002, 29.

\section{Letters and Correspondence}

Dr. William Edwards to Wilbur Siebert. 3 August 1895. Wilbur H. Siebert Collection, Microfilm Edition (MIC 192, Roll 13), Ohio Historical Society, Columbus.

Elizabeth Holderness to W. McLain. 20 March 1855. "Records of the American Colonization Society," Microfilm edition, (Reel 75, no. 564 1/2 ) Library of Congress.

E.M. Stevenson to Wilbur Siebert. 24 February 1897. Wilbur H. Siebert Collection, Microfilm Edition (MIC 192, Roll 13), Ohio Historical Society, Columbus.

George Skipwith to John H. Cocke. 8 July 1847. Reprinted in John W. Blassingame, ed. Slave Testimony: Two Centuries of Letters, Speeches, Interviews and Autobiographies. Lousiana State University Press: Baton Rouge, 1977.

James Catlin to Frederick Douglass. 25 May 1853. Reprinted in The Frederick Douglass Paper, 3 June 1853.

James Lawson to Wilbur Siebert. 22 April 1896. Wilbur H. Siebert Collection, Microfilm Edition (MIC 192, Roll 13), Ohio Historical Society, Columbus.

James Monroe to the Speakers of the General Assembly. 16 January 1802. Reprinted in Stanislaus Murray Hamilton, ed. The Writings of James Monroe, Including a Collection of His Public and Private Papers and Correspondence Now for the first Time Printed. New York: G.P. Putnam's Sons, 1898 - 1903.

James Monroe to Charles Everett. 23 March, 25 April 1812. "Letters of James Monroe," Tyler's Quarterly Historical and Genealogical Magazine 4, 1922, 96.

Jane Randolph to Sarah Nicholas. Undated. Reprinted in Alison Goodyear Freehling. Drift Toward Dissolution. Baton Rouge: Louisiana State University Press, 1982.

J.D. Hunt to Erathus Barns. 15 December 1856. "Abolitionist Papers." Warren County Historical Society, Warren, PA.

John Hogue to Wilbur Siebert. 1895. Wilbur H. Siebert Collection, Microfilm Edition (MIC 192, Roll 13), Ohio Historical Society, Columbus. 
John F. Hogue to Wilbur Siebert. 6 September 1892. Wilbur H. Siebert Collection, Ohio Historical Society, Columbus.

Joseph White to Wilbur Siebert. 23 March 1891. Wilbur H. Siebert Collection, Microfilm Edition (MIC 192, Roll 13), Ohio Historical Society, Columbus.

Joseph White to Wilbur Siebert. 23 March 1893. Wilbur H. Siebert Collection, Microfilm Edition (MIC 192, Roll 13), Ohio Historical Society, Columbus.

Joseph White to Wilbur Siebert. January 1897. Wilbur H. Siebert Collection, Microfilm Edition (MIC 192, Roll 13), Ohio Historical Society, Columbus.

Memorial to the Senate and House of Representatives of the United States. 1838. Slavery - Runaway Papers, Harford County Historical Society; Bel Air, Maryland.

Moses Reeder to Wilbur Siebert. 11 February 1897. Wilbur H. Siebert Collection, Microfilm Edition (MIC 192, Roll 13), Ohio Historical Society, Columbus.

"Son of Wesley Hogue" to Wilbur Siebert. Undated. Wilbur H. Siebert Collection, Microfilm Edition (MIC 192, Roll 13), Ohio Historical Society, Columbus.

S.P. Wright to Wilbur Siebert. 18 January 1896. Wilbur H. Siebert Collection, Microfilm Edition (MIC 192, Roll 13), Ohio Historical Society, Columbus.

Thomas Jefferson to John Holmes. 22 April 1820. Reprinted in Paul Leicester Ford, ed. The Works of Thomas Jefferson, Vol. 12. New York and London: G.P. Putnam's Sons, $1904-1905$.

Unidentified to Mr. McClaskey. Undated. "Miscellaneous letters," Slavery - Runaway Papers, Harford County Historical Society; Bel Air, Maryland.

Unidentified to Wilbur Siebert. 25 November 1895. Wilbur H. Siebert Collection, Microfilm Edition (MIC 192, Roll 13), Ohio Historical Society, Columbus.

Quaker Resolution Against Slavery. 1652. Reprinted in Joanne Grant, ed. Black Protest: 350 Years of History, Documents, and Analyses. New York: Ballatine Books, 1968.

Resolution of Mercer County Anti-Slavery Advocates. 4 July 1835. Reprinted in History of Mercer County (1888), 291.

Resolution of Germantown Mennonites. 18 April 1688. Pennypacker, Samuel. "The Settlement of Germantown and the Causes Which Led to It," The Pennsylvania Magazine of History and Biography, Vol. IV, 1880, 1. 
Wesley Hogue to Wilbur Siebert. Undated. Wilbur H. Siebert Collection, Microfilm Edition (MIC 192, Roll 13), Ohio Historical Society, Columbus.

William B. Giles to Linn Banks. 7 January 1830. Virginia Executive Communications, Box 37, Virginia State Library; Richmond, VA.

William Wirt to Francis Gilmer. 29 January 1821. Davis, Richard Beale. Francis Walker Gilmer: Life and Learning in Jefferson's Virginia. Richmond, VA: The Dietz Press, 1939.

\section{Newspapers}

Alexandria Gazette. 1 December 1835.

Butler Whig. 20 October 1847.

Erie Observer. 11 April 1863.

Indianapolis News. 17 July 1907.

Mercer Dispatch and Republican. 13 June 1930.

Mercer Luminary. 6 October 1841.

Mercer Luminary. 8 March; 1 December 1847.

Mercer Luminary. 10 January; 16, 23 February; 12 July 1848.

New Castle Daily News. 5 March 1897.

Pittsburgh Dispatch. 13 February 1898.

Pittsburgh Gazette. 16 January 1852.

The Advocate. 14 May 1830.

The Frederick Douglass Paper. 25 September 1851; 3 June 1853.

The Mercer Dispatch. 13 March 1908.

The National Era. 26 June 1851.

The National Era. 17 March 1853. 
The National Era. 7 December 1854.

The New Wilmington Globe. 23 August 1973.

The Philadelphia Gazette. 10 June 1795.

The Richmond Enquirer. 17 February 1854.

The Richmond Whig. 25 January 1853.

The Richmond Whig and Public Advertiser. 16 March 1852.

The Sharon Herald. 9 February 1960.

The Sharon Herald. 28 February 2000.

The Sharon Herald. 20 February 2003.

Western Press. 9 December 1837.

Western Press. 13 November 1846.

\section{Public Records}

An Act for the Gradual Abolition of Slavery. Pennsylvania Statutes at Large 10, (1780).

An Act to Explain and Amend "An Act for the Gradual Abolition of Slavery." Pennsylvania Statutes at Large 13, (1788).

An Act respecting Fugitives from Justice, and Persons escaping from the Service of their Masters. U.S. Statutes at Large 1, (1793).

An Act to Amend the Several Laws Concerning Slaves. The Statutes at Large of Virginia, From October Session to December Session 1806, 3, (1806).

An Act to amend, and Supplementary to, the Act entitled "An Act respecting Fugitives from Justice, and Persons escaping from the Service of their Masters." U.S. Statutes At Large 9, (1850).

An Act to Authorize and Empower the Court of Common Pleas of Mercer County to Legitimate Certain Persons who were Emancipated by the Last Will and Testament of Dr. C.D. Everett, late of Albemarle County, Virginia. Laws of the General Assembly of the state of Pennsylvania, 324 (1855). 
Charlottesville, VA. Albemarle County Chancery Orders 3, Historical Record Room Vault; Albemarle County Courthouse.

Charlottesville, VA. Albemarle County Chancery Orders 5, Historical Record Room Vault; Albemarle County Courthouse.

Charlottesville, VA. Albemarle County Chancery Orders 6, Historical Record Room Vault; Albemarle County Courthouse.

Charlottesville, VA. Albemarle County Chancery Orders 7, Historical Record Room Vault; Albemarle County Courthouse.

Charlottesville, VA. Albemarle County Fiduciary Book, No. 1. Historical Record Room Vault; Albemarle County Courthouse.

Charlottesville, VA. Albemarle County Fiduciary Book, No. 3. Historical Record Room Vault; Albemarle County Courthouse.

Charlottesville, VA. Albemarle County Will Book, No. 2. Historical Record Room Vault; Albemarle County Courthouse.

Charlottesville, VA. Albemarle County Will Book, No. 3. Historical Record Room Vault; Albemarle County Courthouse.

Charlottesville, VA. Albemarle County Will Book, No. 23. Historical Record Room Vault; Albemarle County Courthouse.

Harrisburg, PA. 1837. "Grand Inquest of the Commonwealth of Pennsylvania" Court of Oyer and Terminer - Middle District; Pennsylvania State Archives.

Harrisburg, PA. 1839. "Special Verdict," Prigg v. Commonwealth of Pennsylvania. Pennsylvania State Archives.

Mercer, PA. 1856. "Indictment: Malicious Mischief," Commonwealth v. Samuel Bell. Mercer County Prothonotary Office; Mercer County Courthouse.

Mercer, PA. 1863. "Indictment: Larceny," Commonwealth v. John W. Allen. Mercer County Prothonotary Office; Mercer County Courthouse.

Mercer, PA. Mercer County Deed Book, C3. County of Mercer Recorders Office; Mercer County Courthouse.

Mercer, PA. Mercer County Deed Book, D2. County of Mercer Recorders Office; Mercer County Courthouse. 
Mercer, PA. Mercer County Deed Book, E1. County of Mercer Recorders Office; Mercer County Courthouse.

Mercer, PA. Mercer County Deed Book, G1. County of Mercer Recorders Office; Mercer County Courthouse.

Mercer, PA. Mercer County Deed Book, G3. County of Mercer Recorders Office; Mercer County Courthouse.

Mercer, PA. Mercer County Deed Book, I3. County of Mercer Recorders Office; Mercer County Courthouse.

Mercer, PA. Mercer County Deed Book, K2. County of Mercer Recorders Office; Mercer County Courthouse.

Mercer, PA. Mercer County Deed Book, P1. County of Mercer Recorders Office; MercerCounty Courthouse.

Mercer, PA. Mercer County Deed Book, Q3. County of Mercer Recorders Office; MercerCounty Courthouse.

Mercer, PA. Mercer County Quarter Sessions Docket, Book 6, April 1856 to April 1868. Mercer County Clerk of Courts Office; Mercer County Courthouse.

Mercer, PA. Mercer County Quarter Sessions, Book 7, August 1863 to April 1869. Mercer County Clerk of Courts Office; Mercer County Courthouse.

Mercer, PA. Mercer County Quarter Sessions, Book 8, April 1869 to February 1873. Mercer County Clerk of Courts Office; Mercer County Courthouse.

Prigg v. Pennsylvania, 41 U.S. 575 (1842).

Scott v. Sandford, 60 U.S. 393 (1857).

U.S. Constitution, art. IV, sec. 2.

Van Metre v. Mitchell, 28 F. Cas. 1036 ( $3^{\text {rd }}$ Cir. 1853).

York, PA. 1840. "April Sessions 1837 - The Commonwealth v. Edward Prigg, Nathan Bemis, Jacob Forward, Stephen Lewes,” York County Archives.

York, PA. 1840. "Affidavit - Prigg v. the Commonwealth of Pennsylvania," York County Archives. 


\section{General Census Material}

Census for 1820. Published by authority of an act of Congress, under the direction of the Secretary of State. Washinton: Gales and Seaton, 1821.

Abstract of the Returns of the Fifth Census, Showing the Number of Free People, the Number of Slaves, the Federal or Representative Number; and the Aggregate of Each County of Each State of the United States. Washington: Duff Green, 1832.

Compendium of the Enumeration of the Inhabitants and Statistics of the United States, as Obtained at the Department of State, From the Returns of the Sixth Census. Washington: Thomas Allen, 1841.

The Seventh Census of the United States: 1850. Washington: Robert Armstrong, Public Printer, 1853.

Statistical View of the United States, Embracing its Territory, Population-white, free colored, and slave-Moral and Social condition, Industry, Property, and Revenue; the Detailed Statistics of Cities, Towns, and Counties; Being a Compendium of the Seventh Census. Washington: Beverly Tucker, Senate Printer, 1854.

Population of the United States in 1860; Compiled from the Original Returns of the Eighth Census. Washington: Government Printing Office, 1864.

Agriculture of the United States in 1860; Compiled from the Original Returns of the Eighth Census. Washington: Government Printing Office, 1864.

Manufactures of the United States in 1860; Comp. from the Original Returns of the Eighth Census. Washington: Government Printing Office, 1865.

The Statistics of the Population of the United States, Embracing the Tables of Race, Nationality, Sex, Selected Ages, and Occupations. To which are added the statistics of school attendance and illiteracy, of schools, libraries, newspapers, periodicals, churches, pauperism and crime, and of areas, families, and dwellings, Volume 1. Washington: Government Printing Office, 1872.

The Vital Statistics of the United States, Embracing the Tables of Deaths, Births, Sex, and Age. To which are added the statistics of the blind, the deaf, and dumb, the insane, and the idiotic, Volume 2. Washington: Government Printing Office, 1872.

\section{Manuscript Census Material}

Virginia. 1850. Albemarle County Slave Census," Census Series M432, Roll 983. 
Pennsylvania. 1860. Schedule 1 - Free Inhabitants of East Lackawannock in the County of Mercer, State of Pennsylvania, Census Series M653, Roll 1139.

Pennsylvania. 1860. Schedule 1 - Free Inhabitants of Mercer in the County of Mercer, State of Pennsylvania, Census Series M653, Roll 1139.

Pennsylvania. 1860. Schedule 1 - Free Inhabitants of Springfield Township in the County of Mercer, State of Pennsylvania, Census Series M653, Roll 1140.

Virginia. 1860. Albemarle County Slave Census, Census Series M653, Roll 1386.

Pennsylvania. 1870. Schedule 1 - Free Inhabitants in Coolspring Township in the County of Mercer, State of Pennsylvania, Census Series M593, Roll 1374.

Pennsylvania. 1870. Schedule 1 - Free Inhabitants of East Lackawannock in the County of Mercer, State of Pennsylvania, Census Series M593, Roll 1373.

Pennsylvania. 1870. Schedule 1 - Free Inhabitants of Springfield Township in the County of Mercer, State of Pennsylvania, Census Series M593, Roll 1374. 